QA: QA

TDR-EBS-MD-000019 REV 00

March 2001

\title{
External Criticality Risk of Immobilized Plutonium Waste Form in a Geologic Repository
}

By

John A. McClure and Abdelhalim A. Alsaed

Prepared for:

U.S. Department of Energy

Yucca Mountain Site Characterization Office

P.O. Box 30307

North Las Vegas, Nevada 89036-0307

Prepared by:

Bechtel SAIC Company, LLC

1180 Town Center Drive

Las Vegas, Nevada 89144

Under Contract Number

DE-AC08-01NV12101 


\section{DISCLAIMER}

This report was prepared as an account of work sponsored by an agency of the United States Government. Neither the United States Government nor any agency thereof, nor any of their employees, nor any of their contractors, subcontractors or their employees, makes any warranty, express or implied, or assumes any legal liability or responsibility for the accuracy, completeness, or any third party's use or the results of such use of any information, apparatus, product, or process disclosed, or represents that its use would not infringe privately owned rights. Reference herein to any specific commercial product, process, or service by trade name, trademark, manufacturer, or otherwise, does not necessarily constitute or imply its endorsement, recommendation, or favoring by the United States Government or any agency thereof or its contractors or subcontractors. The views and opinions of authors expressed herein do no necessarily state or reflect those of the United States Government or any agency thereof. 


\section{Bechtel SAIC Company, LLC}

External Criticality Risk of Immobilized Plutonium Waste Form in a Geologic Repository TDR-EBS-MD-000019 REV 00

March 2001
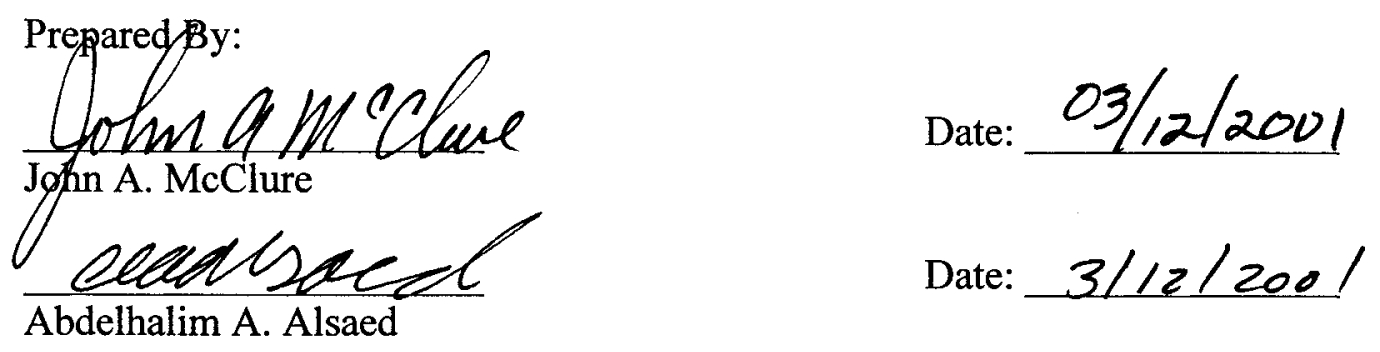

Abdelhalim A. Alsaed

Checked By:

S.F. Alex Deng

Date: $03 / 12 / 2001$

DQU Somar For JPN

Date: $03 / 12 / 2001$

$\mathrm{DCO}_{\text {Susan LeStrange }}$

Date: $03 / 12 / 2001$

Approved By:

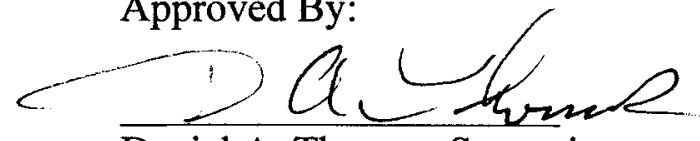

Daniel A. Thomas, Supervisor

Waste Package Criticality

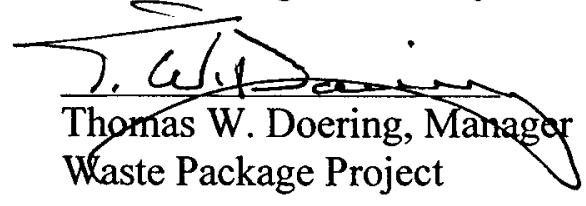

Date: $03 / 12 / 2001$

Date: $03 \cdot 12 \cdot 01$ 


\section{HISTORY OF CHANGE}

$\underline{\text { Rev/Change Number }}$

00 $\underline{\text { Date }}$

March 12, 2001
Description and Reason for Change

Initial Issue 


\section{INTENTIONALLY LEFT BLANK}




\section{ACKNOWLEDGEMENTS}

External Criticality Risk of Immobilized Plutonium Waste Form in a Geologic Repository technical report is a summary of calculations and methods development from a number of authors. This study continues a series begun over six years ago by Peter Gottlieb (TRW). The authors of this study wish to acknowledge the valuable guidance, support, and contributions of Peter Gottlieb to this work. His contributions to this study were an important factor in its accomplishment. Special thanks are also extended to L. Gratton for performing the criticality probability assessments, to P. VanDillen for editing the document, to $\mathrm{H}$. Radulescu for the compliance checking, and to A. Mobasheran for the Product Checking review. 


\section{INTENTIONALLY LEFT BLANK}




\section{EXECUTIVE SUMMARY}

\section{INTRODUCTION AND BACKGROUND}

This technical report provides an updated summary of the waste package (WP) external criticalityrelated risk of the plutonium disposition ceramic waste form, which is being developed and evaluated by the Office of Fissile Materials Disposition of the U.S. Department of Energy (DOE). The ceramic waste form consists of Pu immobilized in ceramic disks, which would be embedded in High-Level Waste (HLW) glass in the HLW glass disposal canisters, known as the "can-incanister" concept, that are externally identical to standard HLW canisters (DOE 1996, p. 5). The cans with the ceramic disks would occupy approximately $12 \%$ of the HLW canister volume, while most of the remaining $88 \%$ of the volume would be occupied by HLW glass.

The criticality investigations have been ongoing for six years. The primary purpose of the current work is to assess the risk on the potential for external criticality, of changing to the Second Enhanced Design Alternative (EDA II) waste package. Relative to previous investigations, this report includes additional refinements to the estimates of the potential accumulation of fissile material external to the waste package and the possibility of a resulting critical mass. In particular, attention is given to the potential for accumulation of fissile material in lithophysae (cavities in the drift rock).

For internal criticality, the principal control measure is the incorporation of gadolinium $(\mathrm{Gd})$ and hafnium (Hf) neutron absorbing materials in the waste form. The potential for criticality is determined primarily by the amount of neutron absorber material remaining in the waste package if, and when, water breaches the waste package, subjecting its contents to aqueous corrosion.

In considering the possibility of external criticality, it is assumed that the solution inside the waste package can flow (or overflow) out to the external environment with the potential for precipitation and accumulation of any dissolved fissile material. The geochemistry code EQ6 is used to evaluate the waste package (WP) degradation producing the external source. The geochemistrytransport code PHREEQC is used to estimate the amount of accumulation of the fissile elements in any fracture network or lithophysae cavity beneath the waste package.

\section{STUDY ACTIVITIES}

The activities begin with assumptions concerning the breach of the waste package and subsequent entry of significant amounts of water. The drip rate of water into the waste package becomes an essential input into the geochemistry degradation calculations (using the code EQ3/6) to determine the waste package solution composition, which becomes the external criticality source term as it drips out of the waste package. The calculations are sufficiently general to account for flow through the waste package (dripping out one or more holes in the lower side) or overflowing of a pond of water in a waste package with no holes in the lower side).

The next step is the geochemistry-accumulation calculation of the fissile material precipitated as the source term flows through the fractures and lithophysae in the rock beneath the waste package. The calculation of the k-effective (effective neutron multiplication factor, $k_{\text {eff }}$ ) values of any 
significant accumulation follows next. The last step is the calculation of the probability for the scenarios that can lead to an accumulation that has a large enough $\mathrm{k}_{\mathrm{eff}}$ to be considered critical.

\section{MAJOR FINDINGS}

Based on the current ceramic formulation (27 kg of Pu per canister), loaded at a maximum of two $\mathrm{Pu}$-bearing canisters per waste package (with the other 3 canister in the waste package containing only HLW glass), this study finds that:

1. Under certain, very unlikely conditions, most of the $\mathrm{Pu}$ payload can be released from the waste package if the waste package solution is made sufficiently alkaline by the aqueous degradation of the HLW glass coupled with a low degradation rate for steel. This waste package outflow is called the external criticality source term. Principal among the required unlikely conditions are the following:

- Both the waste package barriers and the ceramic waste form are corroded by aqueous attack, before most of the ${ }^{239} \mathrm{Pu}$ has decayed to ${ }^{235} \mathrm{U}$.

- Under aqueous attack, the ceramic waste form degrades as fast as does the HLW glass. Such a degradation rate would be at least 10 times larger than the current worst-case estimate provided by the ceramic waste form developers (under the Office of Fissile Materials Disposition).

- Both the waste package barriers and the ceramic waste form are corroded by aqueous attack before most of the ${ }^{239} \mathrm{Pu}$ has decayed to ${ }^{235} \mathrm{U}$.

2. Under additional unlikely conditions, a significant fraction of the $\mathrm{Pu}$ in the source term can be precipitated by mixing or diluting the source term effluent with water of near-neutral $\mathrm{pH}$ that has flowed around the drift, thus modifying the chemical environment containing the actinides. The principal unlikely requirement for this situation is the simultaneous large flow around the waste package and a rather small flow within the waste package.

3. Given a sufficiently large fissile mass available for transport, it would be possible for a critical mass to accumulate if there were a fracture network of sufficient density and aperture directly beneath the waste package. However, fracture statistics from observations in the tunnels and drifts at Yucca Mountain show that the probability of such a high local fracture density is very small.

4. External criticality in non-lithophysal zones is not possible even when using all the upper bounds of the probability distributions applicable to such a zone. This result is due mainly to insufficient moderation.

5. The potential for criticality in the lithophysal zone is conditioned by the occurrence of many unlikely scenarios whose maximum combined probability of $4.32 \times 10^{-12}$ per year is well below the criticality screening threshold of $1.0 \times 10^{-8}$ per year (YMP 2000, Section 3.2.2) 


\section{CONTENTS}

Page

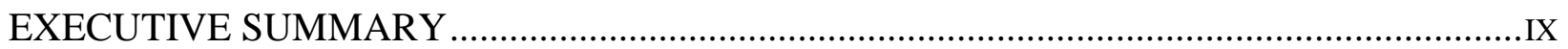

INTRODUCTION AND BACKGROUND …................................................................

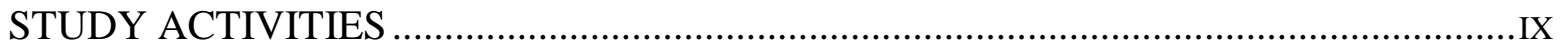

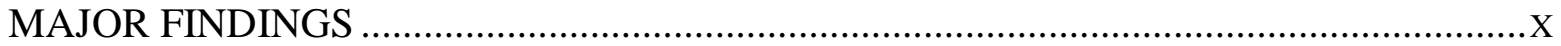

ACRONYMS AND ABBREVIATIONS …......................................................................... XVII

1. INTRODUCTION AND BACKGROUND ….......................................................... $1-1$

2. WASTE FORM AND WASTE PACKAGE DESCRIPTIONS ....................................2-1

2.1 WASTE STREAM QUANTITIES ................................................................ $2-1$

2.2 WASTE FORM DESCRIPTION ............................................................ 2-2

2.2.1 Chemical/Isotopic Composition of the Ceramic Waste Form .....................2-3

2.2.2 Characteristics of HLW Filler Glass........................................................2-6

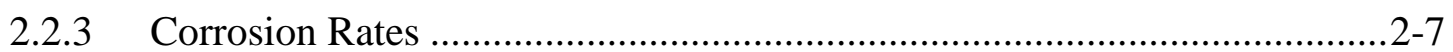

2.3 PLUTONIUM DISPOSITION CANISTER ................................................... $2-8$

2.4 WASTE PACKAGE DESCRIPTION ...................................................... $2-11$

2.5 WASTE PACKAGE AND CANISTER QUANTITIES ...................................2-14

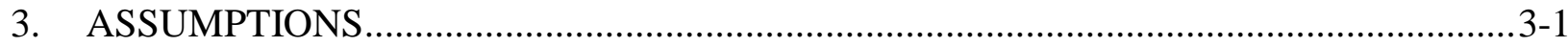

4. QUALITY ASSURANCE REQUIREMENTS ..................................................

5. SOFTWARE USED TO SUPPORT ANALYSES.....................................................

$5.1 \quad$ EQ3/6

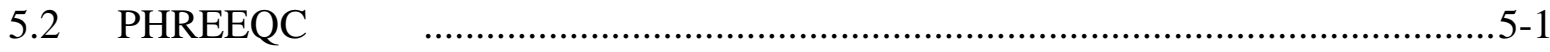

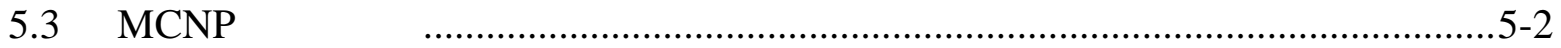

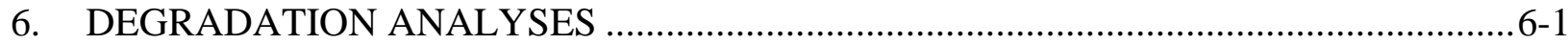

6.1 DEGRADATION ANALYSIS METHODOLOGY …...................................... $6-1$

6.2 DEGRADATION SCENARIOS CONSIDERED FOR THIS STUDY ..................6-2

6.3 DEGRADATION ANALYSIS RESULTS ........................................................

6.3.1 Comparison of Results for Nominal Cases.................................................6-4

6.3.2 Sensitivity Analyses...........................................................................6-6

6.3.3 Worst-Case Source-Term Concentrations .............................................. 6-8

6.3.4 Calculation of ${ }^{235} \mathrm{U}$ Enrichment Fraction in the Effluent............................6-9

7. EXTERNAL ACCUMULATION OF FISSILE MATERIAL .......................................

7.1 ACCUMULATION IN THE INVERT .............................................................

7.2 ACCUMULATION IN THE FAR-FIELD .......................................................

7.2.1 Accumulation in the Far-Field: Mechanisms .......................................... $7-1$

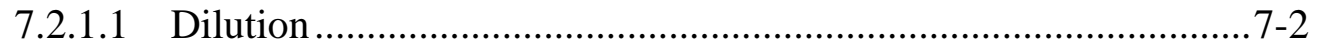

7.2.1.2 Fracture Intensity ............................................................

7.2.1.3 Lithophysae ......................................................................... 


\section{CONTENTS (continued)}

Page

7.2.2 Accumulation in the Far-Field: Results ................................................... $7-5$

7.2.3 Sensitivity Studies ...................................................................... $7-10$

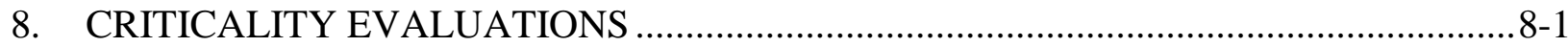

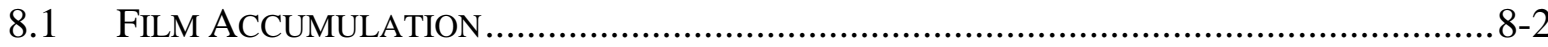

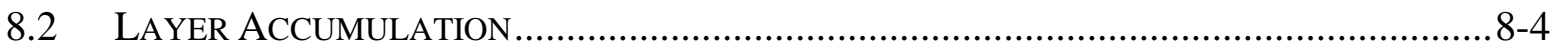

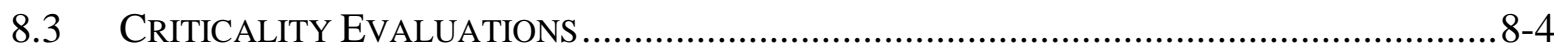

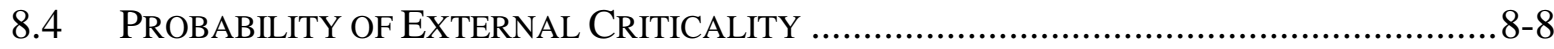

8.4.1 External Criticality Conditions ........................................................... $8-8$

8.4.1.1 Zone in the Repository........................................................... 8

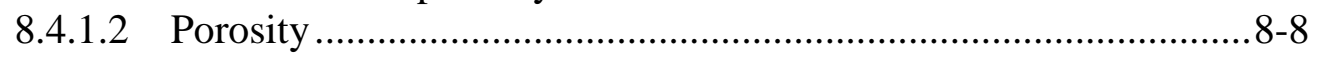

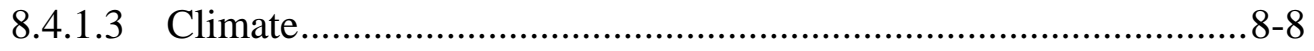

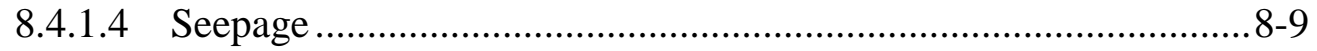

8.4.1.5 Flow into the Waste Package .................................................... 8-9

8.4.1.6 Probability of First Waste Package Breach ................................. 8-9

8.4.1.7 Fractures and Equivalent Fractures Dilution and Saturation ......... 8-9

8.4.1.8 Fracture Intensity ......................................................... 8 -9

8.4.1.9 Probability of Film Accumulation ......................................... 8-11

8.4.2 Layer Accumulation Probability ...................................................... 8-11

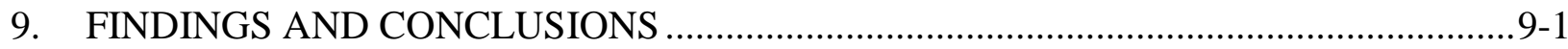

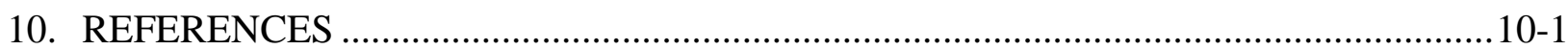

10.1 DOCUMENTS CITED …….................................................................. 10-1

10.2 CODES, STANDARDS, REGULATIONS, AND PROCEDURES .....................10-4

10.3 SOURCE DATA, LISTED BY DATA TRACKING NUMBER ..........................10-5 


\section{FIGURES}

Page

2-1. Can-in-Canister Sketch .......................................................................................... 2-10

2-2. 5-DHLW Waste Package to be Used for Plutonium Immobilized in Ceramic...............2-13

6-1. Mass of $\mathrm{Pu}$ and $\mathrm{Gd}$ in Minerals in Waste Package .......................................................6-6

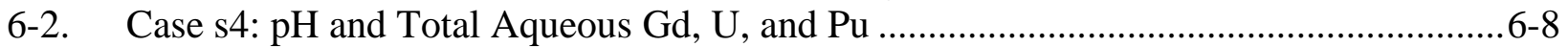

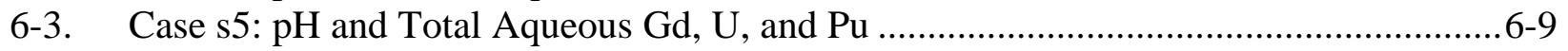

6-4. Case s5: Uranium Enrichment Fraction and Total Aqueous U and Pu .........................6-11

7-1. Sketch of the Drift Dilution Loci ............................................................................ 7-2

7-2. Total Accumulation at 21k after Breach Time (P52rLx41); Pu Decay outside of WP....7-6

7-3. P52rLx41 Scaled Accumulation with Lithophysae (no decay)........................................7-7

7-4. P52\{rs\}L241 Scaled Accumulation with Lithophysae (no decay) ..................................7-7

7-5. Actinide Precipitation as a Function of Dilution (P52rLx41 source term at 7.4k) ..........7-9

7-6. Actinide Precipitation as a Function of Dilution (P52rLx41 source term at 10k) ...........7-9

8-1. Far-Field Representation (not to scale) ................................................................. 8-1

8-2. Far-Field Representation (not to scale) …………….................................................. 8-2

8-3. Probability of a Number of Fractures Intersecting a Characteristic Length ...................8-10 


\section{INTENTIONALLY LEFT BLANK}




\section{TABLES}

2-1. Physical Parameters of Ceramic Bearing Cans ...............................................................2-2

2-2. Input Composition of the Baseline Ceramic Waste Form..................................................2-3

2-3. Impurities in the Pu Process Input Stream .................................................................... 2-4

2-4. Average wt\% Isotopic Composition of the Pu and U Feed in Year 2010..........................2-5

2-5. Average Total Activity of Immobilized Plutonium in a Single Canister in Year 2010 ......2-5

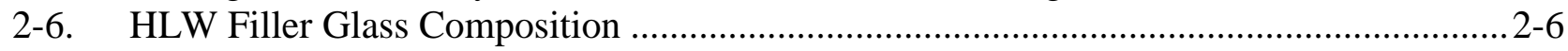

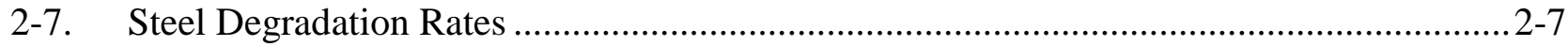

2-8. Glass Degradation Rates ....................................................................................... 2-7

2-9. Pu-Ceramic Degradation Rates .............................................................................. 2-8

2-10. The Main Physical Characteristics of the Five-Defense High-Level Waste Canister Waste

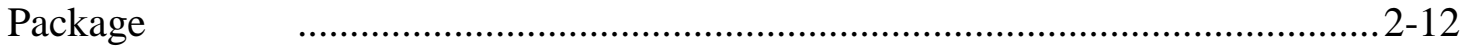

2-11. Numbers of Canisters Required for Disposal of Immobilized Pu................................... 2-14

6-1. Summary of Single-Stage EQ6 Cases for Pu-Ceramic Waste Package.............................. 6-3

6-2. Summary of Multiple-Stage EQ6 Cases for Pu-Ceramic Waste Package ........................... 6-4

6-3. Summary of Gd, Pu, and U Losses for the Primary EQ6 Cases ......................................... 6-5

6-4. Result of Sensitivity Analyses............................................................................... 6-7

7-1. Percentiles of Dilution Factor for the Three Climates (seepage rate between 1 and 20

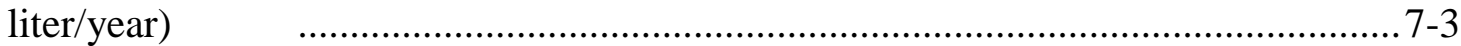

7-2. Summary of Results with a Constant Length Dilution Zone ............................................ 7-8

7-3. Summary of Accumulation in One Meter Diameter Lithophysal Cavity with High Fracture Intensity $\quad$..........................................................................................

8-1. Summary of Accumulation in Fractures Only ……................................................... 8-3

8-2. Summary of Accumulation in Fracture and Lithophysae Equivalent Fractures .................. 8-3

8-3. Summary of Accumulation in Large Spherical Lithophysae ............................................ 8-4

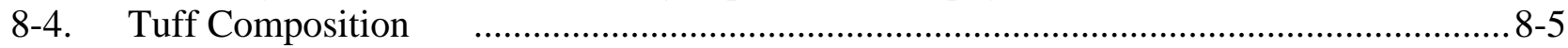

8-5. $\quad \mathrm{k}_{\mathrm{eff}}$ Values for Accumulation in Fractures Only........................................................... 8-5

8-6. $\quad \mathrm{k}_{\mathrm{eff}}$ Values for Accumulation in Fractures and Lithophysae as Equivalent Fractures ........ 8-6

8-7. Critical Volume for Accumulation in Fractures and Lithophysae as Equivalent Fractures 8-7

8-8. $\quad \mathrm{k}_{\mathrm{eff}}$ Values for Accumulation in Relatively Large Spherical Lithophysae........................... 8-7

8-9. Probability Summary of Critical Configuration for Equivalent Fracture System............. 8-11

8-10. Summary of Critical Configuration for Spherical Representation of 1 meter Diameter

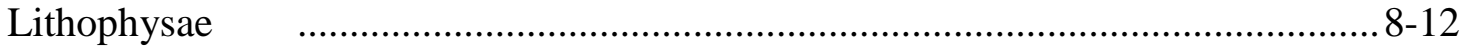

8-11. Summary of Critical Configuration for Spherical Representation of 0.5 meter Diameter Lithophysae 


\section{INTENTIONALLY LEFT BLANK}




\section{ACRONYMS AND ABBREVIATIONS}

$\begin{array}{ll}\text { BSC } & \text { Bechtel SAIC Company, LLC } \\ \text { Ci } & \text { curie } \\ \text { CIC } & \text { can-in-canister } \\ \text { CRWMS } & \text { Civilian Radioactive Waste Management System } \\ \text { CSCI } & \text { Computer Software Configuration Item } \\ \text { DHLW } & \text { defense high-level waste package } \\ \text { DOE } & \text { United States Department of Energy } \\ \text { DWPF } & \text { Defense Waste Processing Facility } \\ \text { EDA II } & \text { Second Enhanced Design Alternative } \\ \text { HLW } & \text { high-level waste } \\ \text { keff } & \text { k-effective } \\ \text { LLNL } & \text { Lawrence Livermore National Laboratory } \\ \text { M\&O } & \text { Management \& Operating } \\ \text { MT } & \text { metric tons } \\ \text { OCRWM } & \text { Office of Civilian Radioactive Waste Management } \\ \text { SCR } & \text { Software Change Request } \\ \text { SNF } & \text { spent nuclear fuel } \\ \text { SQR } & \text { Software Qualification Report } \\ \text { SS } & \text { stainless steel } \\ \text { STN } & \text { Software Tracking Number } \\ \text { VA } & \text { Viability Assessment } \\ \text { VTR } & \text { Validation Test Report } \\ \text { WP } & \text { waste package } \\ \text { wt\% } & \text { weight percent } \\ \text { YMP } & \text { Yucca Mountain Project } \\ \end{array}$




\section{INTENTIONALLY LEFT BLANK}




\section{INTRODUCTION AND BACKGROUND}

This purpose of this technical report is to provide a comprehensive summary of the waste package (WP) external criticality-related risk of the Plutonium Disposition ceramic waste form, which is being developed and evaluated by the Office of Fissile Materials Disposition of the United States Department of Energy (DOE). Potential accumulation of the fissile materials, ${ }^{239} \mathrm{Pu}$ and ${ }^{235} \mathrm{U}$, in rock formations having a favorable chemical environment for such actions, requires analysis because autocatalytic configurations, while unlikely to form, never-the-less have consequences which are undesirable and require evaluation. Secondly, the WP design has evolved necessitating a re-evaluation of the internal WP degradation scenarios that contribute to the external source terms.

The scope of this study includes a summary of the revised WP degradation calculations, a summary of the accumulation mechanisms in fractures and lithophysae in the tuff beneath the WP footprint, and a summary of the criticality risk calculations from any accumulated fissile material. Accumulations of fissile material external to the WP sufficient to pose a potential criticality risk require a deposition mechanism operating over sufficient time to reach required levels. The transporting solution concentrations themselves are well below critical levels (CRWMS 2001e).

The ceramic waste form consists of Pu immobilized in ceramic disks, which would be embedded in High-Level Waste (HLW) glass in the standard HLW glass disposal canister. The ceramic disks would occupy approximately $12 \%$ of the HLW canister volume, while most of the remaining $88 \%$ of the volume would be occupied by HLW glass. This report is in support of the work outlined in the Technical Work Plan for: Plutonium Disposition Work Packages (CRWMS M\&O 2000a) and follows the methodology of the Disposal Criticality Analysis Methodology Topical Report (YMP 2000).

The basic waste package design used for this study is described in Section 2. The design is identical with the one that is planned to be used for the HLW glass. This design is believed to be a considerable improvement over the previous design that was used for the Office of Civilian Radioactive Waste Management (OCRWM) Viability Assessment (VA) of a Repository at Yucca Mountain document. The new design is expected to have a mean lifetime of approximately 100,000 years before water penetration and, at the 95 th percentile confidence level, an earliest time of failure of approximately 20,000 years (CRWMS M\&O 2000b, Figure 3.4-19).

The remaining contents of the report are as follows:

- Section 3 lists and explains the assumptions used for the calculations summarized in this document.

- Section 4 describes the quality assurance requirements applicable to this document.

- Section 5 describes the software used for the calculations summarized in this document.

- Section 6 summarizes the geochemistry degradation calculations internal to the waste package (CRWMS M\&O 2001a). 
- Section 7 summarizes the geochemistry calculations of accumulation external to the waste package (CRWMS M\&O 2001b).

- Section 8 summarizes the neutronics criticality calculations along with an estimate of the probability of criticality for the fissile material accumulations that appear to be closest to a critical mass (CRWMS M\&O 2001c).

- Section 9 provides the findings and conclusions of this study. 


\section{WASTE FORM AND WASTE PACKAGE DESCRIPTIONS}

Immobilized plutonium will arrive at the repository in the form of canisters that are externally identical to the standard HLW canisters used at the Defense Waste Processing Facility (DWPF) at the Savannah River Site, which has been selected as the location for the immobilization facility (65 FR 1608). Smaller cans containing the immobilized plutonium in the form of ceramic disks will be embedded inside each canister. These cans will be surrounded by HLW glass. This is the socalled "can-in-canister" (CIC) concept. The actual design of the CIC has not been finalized; thus, the plutonium loading per canister, volume displaced by the cans, etc., are not yet fixed (Shaw et al. 2001, Section 2.1).

A previous study (CRWMS M\&O 2000f) provided preliminary evaluations of the external criticality risks of an immobilized plutonium waste form using the can-in-canister concept. This report addresses the following design changes:

- EDA II waste package design replacing the VA design

- One or two Pu-bearing canisters per WP in the current study compared with five in the previous studies.

The latest design information (Shaw et al. 2001, Section 2.2) includes a lower Pu loading per canister than was used in the current study $(24.4 \mathrm{~kg}$ versus $27 \mathrm{~kg}$ ) by reducing the weight percent (wt\%) of $\mathrm{Pu}$ in the ceramic waste form from 10.5\% to 9.5\%. Information concerning this design change became available after the degradation calculations were essentially finished. The revised waste form design parameters will be included in any revisions to this document. Thus, the fissile source for external accumulation and criticality evaluations in the present study is approximately $10 \%$ greater than would be obtained from using the latest design specifications.

Disposition of excess weapons plutonium contributes to the U.S. non-proliferation and arms reduction objectives by significantly increasing the difficulty and cost of returning this material to weapons (65 FR 1608, p. 23). Transportation of the plutonium to the repository site is the operation most vulnerable to possible theft. The option of shipping one or two Pu-bearing canisters per cask with similar repository WP disposition benefits the non-proliferation objectives by dispersing the $\mathrm{Pu}$ in smaller quantities over a larger number of containers. This option will also contribute to transportation safeguards because of the smaller unit quantities in a dispersed inventory. However, this option also increases the number of WPs necessary to contain the $\mathrm{Pu}-$ bearing canisters, but the possibility of codisposal with DOE Spent Nuclear Fuel (SNF) may help to minimize the required additional number of WPs. If other WP loading options (more than one or two per WP) are ultimately considered or selected, that information will be incorporated into the next plutonium disposition study.

\subsection{WASTE STREAM QUANTITIES}

Although the January 2000 Record of Decision (65 FR 1608) states that approximately 17 metric tons (MT) of Pu will be subject to immobilization, the total quantity of plutonium that will be immobilized has not yet been finalized (Shaw et al. 2001, Section 2.2). Since the Record of 
Decision was issued, programmatic changes within the DOE have resulted in the withdrawal of some materials from the "pool" of Pu that was originally destined for immobilization. Thus, at the present time, only about $13 \mathrm{MT}$ of Pu are currently earmarked for immobilization, and the design of the immobilization facility is being "sized" to handle this amount of material within the planned 10-year operational lifetime of the facility (Shaw et al. 2001, Section 2.2). Nevertheless, because the quantities and nature of the $\mathrm{Pu}$ that will ultimately be immobilized will remain uncertain, the current work is based on the bounding 17-MT case. Part of the inventory material for immobilization consists of fissile materials other than plutonium. These materials $\left({ }^{235} \mathrm{U},{ }^{236} \mathrm{U}\right.$, ${ }^{241} \mathrm{Am}$, and ${ }^{237} \mathrm{~Np}$ ) are treated as part of the plutonium when formulating the ceramic (Shaw 1999, Section 4).

\subsection{WASTE FORM DESCRIPTION}

The waste form for immobilized $\mathrm{Pu}$ will be a ceramic containing approximately $10.5 \mathrm{wt} \% \mathrm{Pu}$ in the form of $\mathrm{PuO}_{2}$ (Shaw 1999, p. 9). The dominant mineral phase is a titania-based pyrochlore. The basic waste form unit will be a cold-pressed disk. This section provides the current dimensions and composition. The final values will be available as the waste form development project, presently in progress at Lawrence Livermore National Laboratory (LLNL), is completed (Shaw et al. 2001, Section 1).

In the baseline case, each Pu-bearing can will be filled with cylindrical ceramic disks to a nominal maximum fill height of 18.8 inches $(47.75 \mathrm{~cm})$. This corresponds to 20 cylindrical discs that have a nominal diameter of 2.625 inches by 0.94 inches thick. The discs will have an average density of $5.5 \mathrm{~g} / \mathrm{cm}^{3}$ and contain $10.5 \%$ plutonium by weight. Each can will, therefore, nominally contain $0.96 \mathrm{~kg}$ of plutonium, for a total of $27.0 \mathrm{~kg}$ /canister. (Shaw 1999, Section 2). Table 2-1 provides a summary of the physical parameters of ceramic bearing cans (Shaw 1999, Table 2.1).

Table 2-1. Physical Parameters of Ceramic Bearing Cans

\begin{tabular}{|l|l|}
\hline \multicolumn{1}{|c|}{ Parameter } & \multicolumn{1}{c|}{ Value } \\
\hline Outer Height & $20.000 \pm 0.010 \mathrm{in}(50.8 \pm 0.025 \mathrm{~cm})$ \\
\hline Fill Height & $18.8 \pm 0.5 \mathrm{in}(47.8 \pm 1.3 \mathrm{~cm})$ \\
\hline Outer Diameter & $3.000 \pm 0.005 \mathrm{in}(7.62 \pm 0.13 \mathrm{~cm})$ \\
\hline Gross Volume & $141.4 \mathrm{in}^{3}(2.32$ liter $)$ \\
\hline Wall Thickness & $0.06 \pm 0.015 \mathrm{in}(0.15 \pm 0.038 \mathrm{~cm})$ \\
\hline Material & Type 304 stainless steel \\
\hline Empty Mass & $3.44 \mathrm{lb}(1.56 \mathrm{~kg})$ \\
\hline Ceramic Disk Diameter & $2.625+0.125,-0.225$ in $(6.73+0.317-0.517 \mathrm{~cm})$ \\
\hline Ceramic Disk Thickness & 0.94 in $($ no tolerance $)(2.4 \mathrm{~cm})$ \\
\hline Ceramic Discs per Can & nominally $20($ based on final pellet thickness $)$ \\
\hline Ceramic Mass per Can & nominally $20.2 \mathrm{lb}(9.2 \mathrm{~kg})$ \\
\hline
\end{tabular}




\subsubsection{Chemical/Isotopic Composition of the Ceramic Waste Form}

The principal chemical components of the waste form are specified in Table 2-2 (LLNL 1998, Table 3.1, Baseline Composition) and are the same components used in the previous degradation calculation (CRWMS M\&O 1999a, Table 5.3). The average concentration of impurities in the $\mathrm{Pu}$ stream that will be in the final ceramic (i.e., that survive the ceramic formation process) is specified in Table 2-3 (Shaw 1999, Table 3.3). The impurities, plus oxygen, are $27.2 \mathrm{wt} \%$ of the total $\mathrm{Pu}$ feed with $72.8 \mathrm{wt} \%$ of the feed being Pu. Since the amount of feed is always adjusted so the $\mathrm{Pu}$ will be $10.5 \mathrm{wt} \%$ of the total ceramic, the impurities in the Pu feed will constitute $3.92 \mathrm{wt} \%$ of the total ceramic weight $(=27.2 * 10.5 / 72.8)$ for the $17 \mathrm{MT}$ case. Note that the value of the $\mathrm{Pu}$ $\mathrm{wt} \%$ (10.5) is used in this calculation, rather than the value of $\mathrm{PuO}_{2} \mathrm{wt} \%$ (11.93) to be consistent with the oxygen of $\mathrm{PuO}_{2}$ already having been included in the non-Pu component of the feed.

The average initial Pu-related isotopic composition of the feed stream is given in Table 2-4. The data are taken from Tables 4.1 and 4.2 of the LLNL report (Shaw et al. 2001).

Table 2-2. Input Composition of the Baseline Ceramic Waste Form

\begin{tabular}{|c|c|}
\hline Component & $\mathbf{W t} \%$ \\
\hline $\mathrm{CaO}$ & 10.0 \\
\hline $\mathrm{HfO}_{2}$ & 10.6 \\
\hline $\mathrm{UO}_{2}$ & 23.7 \\
\hline $\mathrm{PuO}_{2}$ & 11.9 \\
\hline $\mathrm{Gd}_{2} \mathrm{O}_{3}$ & 7.9 \\
\hline $\mathrm{TiO}_{2}$ & 35.9 \\
\hline $\mathrm{Al}_{2} \mathrm{O}_{3}$ & 0.00 \\
\hline
\end{tabular}


Table 2-3. Impurities in the Pu Process Input Stream

\begin{tabular}{|c|c|}
\hline Element & wt\% of Pu Stream \\
\hline $\mathrm{Al}$ & 1.856 \\
\hline $\mathrm{Am}$ & 1.582 \\
\hline $\mathrm{B}$ & 0.088 \\
\hline $\mathrm{Ba}$ & 0.208 \\
\hline $\mathrm{Ce}$ & 0.088 \\
\hline $\mathrm{Cr}$ & 0.137 \\
\hline $\mathrm{Cu}$ & 0.094 \\
\hline $\mathrm{Fe}$ & 0.625 \\
\hline $\mathrm{Ga}$ & 0.495 \\
\hline $\mathrm{K}$ & 0.711 \\
\hline $\mathrm{La}$ & 0.030 \\
\hline $\mathrm{Mg}$ & 1.141 \\
\hline Mo & 0.625 \\
\hline $\mathrm{Na}$ & 0.357 \\
\hline $\mathrm{Ni}$ & 0.289 \\
\hline $\mathrm{Nd}$ & 0.580 \\
\hline $\mathrm{Np}$ & 0.053 \\
\hline O & 15.415 \\
\hline $\mathrm{Pb}$ & 0.009 \\
\hline $\mathrm{Si}$ & 1.055 \\
\hline Sn & 0.003 \\
\hline $\mathrm{Ta}$ & 0.964 \\
\hline W & 0.019 \\
\hline $\mathrm{Zn}$ & 0.088 \\
\hline Unknown & 0.667 \\
\hline Total & 27.19 \\
\hline
\end{tabular}


Table 2-4. Average wt\% Isotopic Composition of the Pu and U Feed in Year 2010

\begin{tabular}{|c|c|}
\hline Isotope & $\begin{array}{c}\text { wt\% } \\
\text { 17-MT Case }\end{array}$ \\
\hline${ }^{235} \mathrm{U}$ & 1.69 \\
\hline${ }^{238} \mathrm{U}^{\mathrm{a}}$ & 98.31 \\
\hline${ }^{238} \mathrm{Pu}$ & 0.12 \\
\hline${ }^{239} \mathrm{Pu}$ & $90.72^{\mathrm{c}}$ \\
\hline${ }^{240} \mathrm{Pu}$ & 8.59 \\
\hline${ }^{241}(\mathrm{Pu}+\mathrm{Am})^{\mathrm{b}}$ & 0.24 \\
\hline${ }^{242} \mathrm{Pu}$ & 0.33 \\
\hline
\end{tabular}

NOTES: ${ }^{\mathrm{a}}$ Remainder of uranium

${ }^{\mathrm{b}}$ Since ${ }^{241} \mathrm{Pu}$ has a half-life of only 14 years, virtually all the ${ }^{241} \mathrm{Pu}$ would have decayed into ${ }^{241} \mathrm{Am}$ by the time there is any possibility of criticality (upwards of 10,000 years)

${ }^{\mathrm{C}} \mathrm{Pu}$ in calculations assumed $100 \%{ }^{239} \mathrm{Pu}$ (see Section 6.1)

It should be noted that by the time of any potential criticality, much of the ${ }^{239} \mathrm{Pu}$ would have decayed into ${ }^{235} \mathrm{U}$. A conservative estimate of this decay at the time of potential criticality is given in the description of the configurations that are likely to have potential for criticality.

The only significant radioactivity in the waste form itself derives from the $\mathrm{Pu}$ feed and will have approximately the distribution indicated in Table 2-5 in the year 2010. This table lists Curies per canister (27 kg fissile material) of the feed and is taken from Table 4.6 of the LLNL report (Shaw 1999).

Table 2-5. Average Total Activity of Immobilized Plutonium in a Single Canister in Year 2010

\begin{tabular}{|c|c|}
\hline Isotope & $\begin{array}{c}\text { Activity } \\
\text { (Curies [Ci] per Canister) }\end{array}$ \\
\hline${ }^{238} \mathrm{Pu}$ & 115 \\
\hline${ }^{239} \mathrm{Pu}$ & 1517 \\
\hline${ }^{240} \mathrm{Pu}$ & 517 \\
\hline${ }^{241} \mathrm{Pu}$ & 4452 \\
\hline${ }^{242} \mathrm{Pu}$ & 0.092 \\
\hline${ }^{241} \mathrm{Am}$ & 675 \\
\hline${ }^{235} \mathrm{U}$ & $2.2 \mathrm{E}-3$ \\
\hline${ }^{238} \mathrm{U}$ & $1.8 \mathrm{E}-2$ \\
\hline Total & 7276 \\
\hline
\end{tabular}




\subsubsection{Characteristics of HLW Filler Glass}

The baseline fill volumes of the glass per HLW canister range from 629 to 705 liters (Shaw 1999, Section 2) at a density of $2.85 \mathrm{~g} / \mathrm{cm}^{3}$ (conservative value, Baxter 1988, pp. 54-57, Assumption 3.1.8) subject to a canister mass limit of $2500 \mathrm{~kg}$ (DOE 1996, Section 3.11). The chemical composition of the HLW filler glass used for the degradation calculations is given in Table 2-6 (CRWMS M\&O 2001a, Table 5-3). Certain trace elements have been removed or merged with chemically similar elements resulting in a simplified composition (as explained in the comment column of the table).

Table 2-6. HLW Filler Glass Composition

\begin{tabular}{|c|c|c|}
\hline Element & Moles & Comment \\
\hline $\mathrm{O}$ & 2.7038 & \\
\hline U & 0.0078 & \\
\hline $\mathrm{Np}$ & 0 & Merged with $U$ ( $0.1 \%$ of actinides, ceramic Np overwhelms) \\
\hline $\mathrm{Pu}$ & 0 & Merged with $\mathrm{U}(\mathrm{Pu} \sim 1 \%$ actinides, ceramic Pu overwhelms glass $\mathrm{Pu})$. \\
\hline $\mathrm{Ba}$ & 0.0011 & \\
\hline $\mathrm{Al}$ & 0.0863 & \\
\hline S & 0.0040 & \\
\hline $\mathrm{Ca}$ & 0.0162 & \\
\hline $\mathrm{P}$ & 0.0005 & \\
\hline $\mathrm{Cr}$ & 0 & Merged with $\mathrm{Al}$ (overwhelmed by steel $\mathrm{Cr} ; \mathrm{Cr}_{2} \mathrm{O}_{3}$ similar to $\mathrm{Al}_{2} \mathrm{O}_{3}$ ) \\
\hline $\mathrm{Ni}$ & 0 & Merged with Fe \\
\hline $\mathrm{Pb}$ & 0 & Merged with $\mathrm{Ba}$ (both form insoluble $\left(\mathrm{CrO}_{4}\right)^{-2}$ compounds in EQ6 runs) \\
\hline $\mathrm{Si}$ & 0.7765 & \\
\hline $\mathrm{Ti}$ & 0 & Merged with $\mathrm{Si}$ (overwhelmed by ceramic $\mathrm{Ti} ; \mathrm{TiO}_{2}$ similar to $\mathrm{SiO}_{2}$ ) \\
\hline B & 0.2912 & \\
\hline $\mathrm{Li}$ & 0 & Merged with $\mathrm{Na}$ \\
\hline $\mathrm{F}$ & 0.0017 & \\
\hline $\mathrm{Cu}$ & 0 & Merged with Fe \\
\hline $\mathrm{Fe}$ & 0.1722 & \\
\hline K & 0.0752 & \\
\hline $\mathrm{Mg}$ & 0.0333 & \\
\hline $\mathrm{Mn}$ & 0 & Merged with Fe \\
\hline $\mathrm{Na}$ & 0.5767 & \\
\hline $\mathrm{Cl}$ & 0 & Removed (overwhelmed by $\mathrm{Cl}$ in in-dripping water) \\
\hline
\end{tabular}




\subsubsection{Corrosion Rates}

Table 2-7 provides a summary of the compositions of the principal alloys used in the WP degradation calculations (CRWMS M\&O 2001a, Table 5-2), along with a range of degradation rates. The degradation rate for the A-516 carbon steel and the "low" rates for the stainless steels are comparable (within a factor of 2) to the values used in a prior calculation (CRWMS M\&O 1999a, Table 5-1). The "average" and "high" values for the stainless steels in Table 2-7 are significantly higher than the highest value of $1 \mu \mathrm{m} / \mathrm{y}$ used in the previous calculation.

Table 2-7. Steel Degradation Rates

\begin{tabular}{|l|c|l|c|c|c|c|}
\hline \multirow{2}{*}{ Rate } & \multicolumn{2}{|c|}{ A-516 Carbon Steel } & \multicolumn{2}{c|}{ 316L Stainless Steel } & \multicolumn{2}{c|}{ 304L Stainless Steel } \\
\cline { 2 - 7 } & $(\mu \mathrm{m} / \mathbf{y})$ & $\left(\mathbf{m o l e} /\left(\mathbf{c m}^{\mathbf{2}} \cdot \mathbf{s}\right)\right)^{\mathbf{a}}$ & $(\mu \mathrm{m} / \mathbf{y})$ & $\left(\mathbf{m o l e} /\left(\mathbf{c m}^{2} \cdot \mathbf{s}\right)\right)$ & $(\mu \mathrm{m} / \mathbf{y})$ & $\left(\mathbf{m o l e} /\left(\mathbf{c m}^{2} \cdot \mathbf{s}\right)\right)$ \\
\hline Very Low & $\begin{array}{c}\text { Same as } \\
\text { average }\end{array}$ & Same as average & $0.01^{\mathrm{b}}$ & $2.53 \mathrm{E}-15$ & $\begin{array}{c}\text { Same as } \\
\text { low }\end{array}$ & Same as low \\
\hline Low & $\begin{array}{c}\text { Same as } \\
\text { average }\end{array}$ & Same as average & 0.1 & $2.53 \mathrm{E}-14$ & 0.1 & $2.52 \mathrm{E}-14$ \\
\hline Average & 72 & $1.79 \mathrm{E}-11$ & 2 & $5.06 \mathrm{E}-13$ & 34 & $8.55 \mathrm{E}-12$ \\
\hline High & $\begin{array}{c}\text { Same as } \\
\text { average }\end{array}$ & Same as average & 33 & $8.34 \mathrm{E}-12$ & 208 & $5.23 \mathrm{E}-11$ \\
\hline
\end{tabular}

NOTES: ${ }^{a}$ The molecular weight of each material is assumed to be 100 grams. The degradation rates in units of $\mu \mathrm{m} / \mathrm{y}$ are multiplied by the density, divided by $10^{4} \mu \mathrm{m} / \mathrm{cm}$, divided by $100 \mathrm{~g} / \mathrm{mole}$, divided by 365.25 days $/ y$, and divided by $86,400 \mathrm{~s} /$ day to convert to units of $\mathrm{mole} /\left(\mathrm{cm}^{2} \cdot \mathrm{s}\right)$.

${ }^{b}$ The very low rate for $316 \mathrm{~L}$ was assumed to be 10 times lower than the low rate.

A pH-dependent degradation rate abstraction was used for the HLW glass as given in Table 2-8 (CRWMS M\&O 2001a, Table 5-3). The "high" rate was chosen to correspond to $50{ }^{\circ} \mathrm{C}$.

Table 2-8. Glass Degradation Rates

\begin{tabular}{|l|c|}
\hline \multicolumn{1}{|c|}{ Degradation Rate ${ }^{\mathrm{a}}$} & Coefficients \\
\hline Average & $\mathrm{k}_{1}=8.86 \mathrm{E}-19, \mathrm{k}_{2}=7.98 \mathrm{E}-13$ liter $/ \mathrm{cm}^{2} \cdot \mathrm{s}$ \\
\hline Moderately High & $\mathrm{k}_{1}=7.06 \mathrm{E}-18, \mathrm{k}_{2}=3.59 \mathrm{E}-12$ liter $/ \mathrm{cm}^{2} \cdot \mathrm{s}$ \\
\hline High & $\mathrm{k}_{1}=1.08 \mathrm{E}-17, \mathrm{k}_{2}=4.87 \mathrm{E}-12$ liter $/ \mathrm{cm}^{2} \cdot \mathrm{s}$ \\
\hline
\end{tabular}

NOTE: ${ }^{a}$ Degradation Rate $=\mathrm{k}_{1}[\mathrm{H}+]^{-0.04}+\mathrm{k}_{2}[\mathrm{H}+]^{0.6}\left(\mathrm{~mole} / \mathrm{cm}^{2} \cdot \mathrm{s}\right)(\mathrm{CRWMS} \mathrm{M \& O}$ 2001e, Section 6.2.3) (Equations 7 and 8 converted to EQ6 units)

The constant degradation rates used for the Pu-ceramic are provided in Table 2-9 (CRWMS M\&O 2001c, Table 5-4). The high rate was estimated in a previous calculation (CRWMS M\&O 2000j, p. 27), based on $50^{\circ} \mathrm{C}$ rates for radiation-damaged ceramic from Shaw (1999), Section 6.1. The very high rate and the average rate were chosen to be a factor of 10 higher and lower, respectively, than the high rate. 
Table 2-9. Pu-Ceramic Degradation Rates

\begin{tabular}{|c|c|}
\hline Rate & $\left(\mathbf{m o l e} /\left(\mathbf{c m}^{2} \cdot \mathbf{s}\right)\right)^{\mathbf{a}}$ \\
\hline Average & $8.0 \mathrm{E}-16$ \\
\hline High & $8.0 \mathrm{E}-15$ \\
\hline Very High & $8.0 \mathrm{E}-14$ \\
\hline
\end{tabular}

Source: $\quad$ High rate (CRWMS M\&O 2000j, p. 27) based on Shaw 1999, Section 6.1

NOTE: $\quad{ }^{\mathrm{a} O n e}$ mole $\equiv 100 \mathrm{~g}$.

It should be noted that the aqueous corrosion (or degradation) of individual solid waste package components does not necessarily lead directly to removal from the waste package of elements or ions from those corroded components. Individual elements may remain in a solid altered state, or precipitate as some insoluble mineral.

\subsection{PLUTONIUM DISPOSITION CANISTER}

The waste forms are contained within the waste packages in 304L stainless steel (SS) DWPF canisters approximately 3 meters overall length, $61 \mathrm{~cm}$ outer diameter, and $0.95 \mathrm{~cm}$ wall thickness. The disks are stacked in cans, 20 disks per can. The SS cans are stacked four deep in very thinwalled 304L SS tubes. There will also be a magazine rack to space and separate the cans within these tubes. There will be seven of these tubes fastened at the inside wall of a HLW canister. While the final design has not yet been specified, a sketch of a likely arrangement from the Savannah River Site showing cross section with four cans in a tube and seven tubes in a HLW canister is given in Figure 2-1 (Shaw 1999, Figure 2.1). This results in a total of 28 cans, or 560 disks, per HLW canister.

The DWPF canister characteristics are given as follows (Shaw 1999, Section 2):

- HLW glass displaced by $\mathrm{Pu}$ waste form cans magazines, and racks $\quad 12 \%$

- Mass of HLW canister (empty) $\quad 499 \mathrm{~kg}$

$\begin{array}{lll}\text { - Ceramic mass } & 256.8 \mathrm{~kg}\end{array}$

- Mass of magazine, rack, and empty cans (nominal) $206 \mathrm{~kg}$

- range 180 to $290 \mathrm{~kg}$

- HLW glass per canister (nominal [540 liters @ 2.85 g/ $\mathrm{cm}^{3}$ ] $\quad 1538 \mathrm{~kg}$ to not exceed $2500 \mathrm{~kg}$ ) 
With these parameters, the total loaded canister masses are:

- $\quad$ Canister with HLW glass only $(0.85 * \operatorname{vol} * 2.85+499)$

$2282 \mathrm{~kg}$ (fill volume approximately 85\% [CRWMS M\&O 2000h, Section 4.1.2])

- Canister containing both ceramic and HLW glass (max)

$2500 \mathrm{~kg}$

Using the conservative density of $2.85 \mathrm{~g} / \mathrm{cm}^{3}$ for the glass results in a fill capacity of approximately 625 liters that is within the design capacity of 636 liters (Shaw 1999, p. 3). The glass composition has not been finalized and, thus, its density has a range of possible values introducing some uncertainty in the actual HLW glass mass per canister. Likewise the magazine and rack design has not been finalized adding to the uncertainty in the total mass of the canister. 


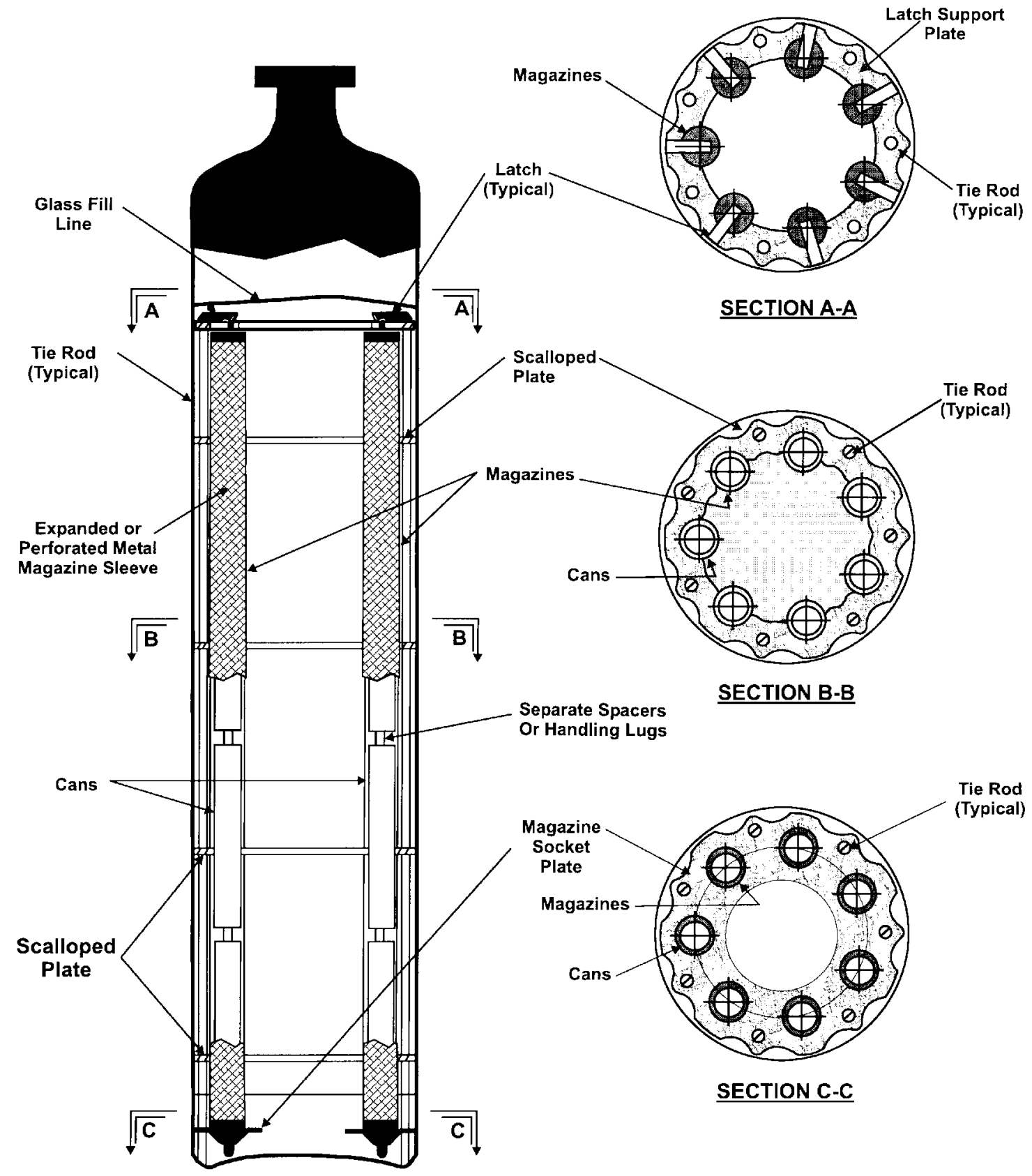

Figure 2-1. Can-in-Canister Sketch 


\subsection{WASTE PACKAGE DESCRIPTION}

The disposal container will be the same 5-Defense High-Level Waste Package (DHLW) design as is planned for the ordinary HLW canisters. As explained previously, for transportation safeguards considerations, the nominal $\mathrm{Pu}$ loading per waste package is taken to be one $\mathrm{Pu}$-loaded canister per waste package with the worst case being two per package due to human error.

The 5-DHLW/DOE SNF short disposal container consists of two concentric right-circular cylindrical shells. The inner shell is comprised of 5-cm thick 316 SS that provides structural support as well as serving as barrier. The outer shell is comprised of a $2.5-\mathrm{cm}$ thick, high nickel content, alloy (Alloy 22) that provides a corrosion resistant barrier. The waste package cavity allows a uniform emplacement of 5-DHLW glass canisters surrounding an 18 inches $(45.72 \mathrm{~cm})$ diameter standardized DOE SNF canister. The dimensions and compositions of the intact WP components are provided in Table 2-10 (CRWMS M\&O 2000h, Attachment III).

A 3.175-cm thick carbon steel guide and support tube having a nominal outer diameter of $56.5 \mathrm{~cm}$ separates the DOE SNF canister from the DHLW glass canisters. The guide tube is connected to the inside SS shell by a web-like structure of carbon steel plates to support the five DHLW glass canisters.

An isometric view of the 5-DHLW waste package is given in Figure 2-2, showing the inner and outer barriers, lids, and inner structures. 
Table 2-10. The Main Physical Characteristics of the Five-Defense High-Level Waste Canister Waste Package

\begin{tabular}{|c|c|c|c|c|c|c|c|}
\hline Component & Number & Material & $\begin{array}{l}\text { Inner } \\
\text { Diameter } \\
(\mathbf{c m})\end{array}$ & $\begin{array}{c}\text { Outer } \\
\text { Diameter } \\
(\mathrm{cm})\end{array}$ & $\begin{array}{l}\text { Thickness } \\
\text { (cm) }\end{array}$ & $\begin{array}{l}\text { Inner } \\
\text { Length } \\
(\mathrm{cm})\end{array}$ & $\begin{array}{c}\text { Outer } \\
\text { Length } \\
\text { (cm) }\end{array}$ \\
\hline Outer Barrier & 1 & $\begin{array}{c}\text { ASTM B-575 } \\
\text { N06022 } \\
\text { (Alloy 22) }\end{array}$ & 198 & 203 & 5.0 & ------- & 359 \\
\hline \multirow{3}{*}{$\begin{array}{c}\text { Outer Barrier } \\
\text { Lid }\end{array}$} & $\begin{array}{l}1 \text { (extended } \\
\text { closure) }\end{array}$ & \multirow{3}{*}{$\begin{array}{c}\text { ASTM B-575 } \\
\text { N06022 } \\
\text { (Alloy 22) }\end{array}$} & --------- & 199.7 & 2.5 & -------- & -------- \\
\hline & $\begin{array}{c}1 \text { (top } \\
\text { closure) }\end{array}$ & & ------- & 198.3 & 1.0 & -------- & ------- \\
\hline & $\begin{array}{l}1 \text { (bottom } \\
\text { closure) }\end{array}$ & & -------- & 198.6 & 2.5 & ------- & ------ \\
\hline Inner Barrier & 1 & $\begin{array}{c}\text { ASTM A-240 } \\
\text { S31600 } \\
\text { (316 SS) }\end{array}$ & 188 & 198 & 5.0 & 320 & ------- \\
\hline $\begin{array}{c}\text { Inner Barrier } \\
\text { Lid }\end{array}$ & $\begin{array}{c}2 \text { (top and } \\
\text { bottom) }\end{array}$ & $\begin{array}{c}\text { ASTM A-240 } \\
\text { S31600 } \\
\text { (316 SS) }\end{array}$ & ----------- & 188.6 & 8.0 & -------- & -------- \\
\hline Canister $^{\mathrm{a}}$ & 5 & $\begin{array}{c}\text { ASTM A-312 } \\
\text { Type 304L } \\
\text { Stainless } \\
\text { Steel }\end{array}$ & 59.095 & 61.0 & 0.9525 & -------- & 300.0 \\
\hline
\end{tabular}

Source: ' ${ }^{2}$ CRWMS M\&O 2000h, Section 4.1 


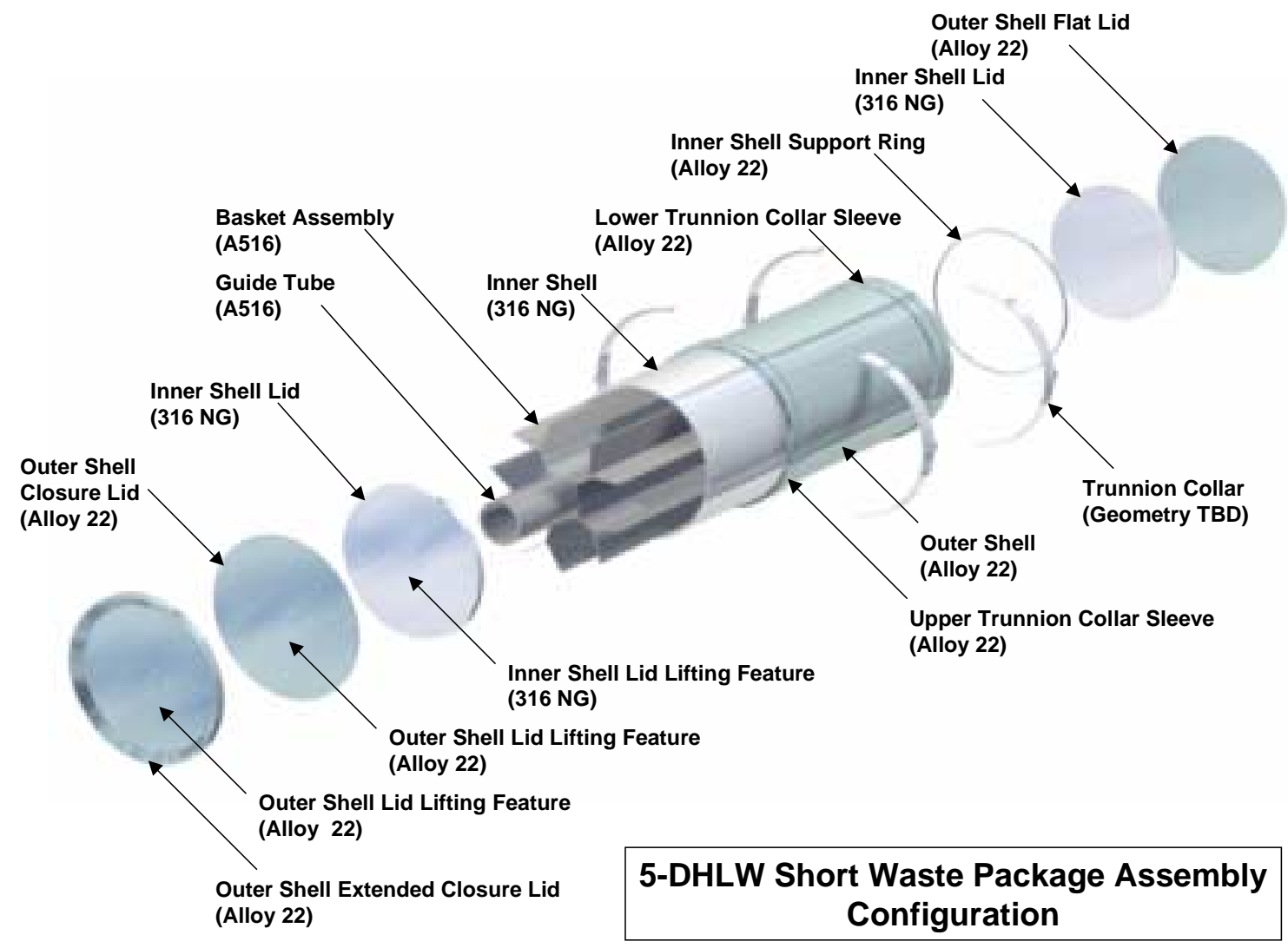

NOTE: NG stands for Nuclear Grade

Figure 2-2. 5-DHLW Waste Package to be Used for Plutonium Immobilized in Ceramic 


\subsection{WASTE PACKAGE AND CANISTER QUANTITIES}

The total number of canisters required for disposal is summarized in Table 2-11 based on 27 $\mathrm{kg} /$ canister of fissile material and the bounding disposal quantity of $17 \mathrm{MT}$ of plutonium (all fissile material). This is also the number of WPs required, assuming one canister per WP. Also given in the table is the number of waste packages required at 5 canisters per waste package that is the maximum possible waste package loading.

Table 2-11. Numbers of Canisters Required for Disposal of Immobilized Pu

\begin{tabular}{|l|c|}
\hline \multicolumn{1}{|c|}{ Item Description } & Value \\
\hline Number of Pu containing canisters in WPs & 631 \\
\hline $\begin{array}{l}\text { Net additional canisters to accommodate DHLW filler displaced by the Pu ceramic } \\
(631 * 0.12)\end{array}$ & 76 \\
\hline Net additional canisters as a \% of total HLW canisters $(\sim 12,000$, thus $76 / 12000)$ & $0.6 \%$ \\
\hline Number of waste packages containing Pu (5 canisters per waste package) & 127 \\
\hline Net additional waste packages $(127 * 0.12)$ & 16 \\
\hline
\end{tabular}

It should be noted that since the Pu-bearing canisters contain $88 \%$ of their maximum capacity for HLW glass, the impact of immobilized-Pu disposal on the number of waste packages is only the net increase required to make up for the $12 \%$ of the HLW displaced by the plutonium-bearing cans and their accompanying structure. This net increase for canisters is shown by the second line of Table 2-11, and for waste packages by the fifth line. 


\section{INTENTIONALLY LEFT BLANK}




\section{ASSUMPTIONS}

Section 3 lists and explains the key assumptions used for the calculations summarized in this report. For the most part, these assumptions are included in this document for informational purposes and are for reference only. Any assumptions pertaining specifically to this document are so identified.

\subsection{CHEMICAL DEGRADATION OF PU-CERAMIC WASTE PACKAGES}

The assumptions listed in this subsection are used throughout Section 6.

3.1.1 It is assumed that the solutions that drip into the waste package will have the major ion composition of J-13 well water (DTN: MO0006J13WTRCM.000), and that minor components in the solution can be represented as given by Harrar et al. 1990, Table 4.2 for $6.35 \cdot 10^{5}$ years. The rationale for this assumption is that the groundwater composition is controlled largely by transport through the host rock, over pathways of hundreds of meters, and the host rock composition is not expected to change substantially over $10^{6}$ years. The assumption that the water entering the waste package can be approximated by the J-13 well water implicitly assumes that any effects of contact with the engineered materials in the drift will be minimal after a few thousand years. For a few thousand years after waste emplacement, the composition may differ because of perturbations resulting from reactions with engineered materials and from the thermal pulse. These are not taken into account in the calculation because the outer shell and inner liner are not expected to breach until after that perturbed period. Therefore, the early perturbation is not relevant to the degradation calculations.

3.1.2 In general, it is assumed that chromium and molybdenum will oxidize fully to chromate (or dichromate) and molybdate, respectively. The rationale for this assumption is based on the available thermodynamic data listed in Section 5 of CRWMS M\&O (2001a), which indicate that in the presence of air, the chromium and molybdenum would both oxidize to the VI valence state.

3.1.3 It is assumed that precipitated solids that are deposited remain in place and are not mechanically eroded or entrained as colloids in the advected water. The rationale for this assumption is that it allows continual contact and opportunity for reaction between liquid and solid phases within the waste package.

3.1.4 It is assumed that the rate of entry of water into, as well as the rate of egress from, a waste package is equal to the rate at which water drips onto the waste package. The rationale for this assumption is that for most of the time frame of interest, i.e., long after the outer barriers become largely degraded, it is more reasonable to assume that all or most of the dripping water will enter the degraded waste package than to assume that a significant portion will instead be diverted around the remains. However, the calculations include scenarios with very low drip rates, which effectively simulate diversion of the bulk of the water striking the waste package. 
3.1.5 It is assumed that water will circulate freely enough in the partially degraded waste package that all degraded solid products will react with each other through the aqueous solution medium. The rationale for this assumption is that it provides the most rapid aqueous degradation and is, therefore, conservative.

3.1.6 It is assumed that gases in the WP solution remain in equilibrium with the ambient atmosphere outside the WP. In other words, contact of WP fluids with the gas phase in the repository is envisioned to be sufficient to maintain equilibrium with the $\mathrm{CO}_{2}$ and $\mathrm{O}_{2}$ present, whether or not this is the normal atmosphere in open air or rock gas that seeps out of the adjacent tuff. Moreover, the specific partial pressures of $\mathrm{CO}_{2}$ and $\mathrm{O}_{2}$ of the ambient repository atmosphere are set to, respectively, 10-3.0 and 10$0.7 \mathrm{~atm}$. The rationale for the oxygen partial pressure is that it is equivalent to that in the atmosphere (Weast 1977, p. F-210). The rationale for choosing the carbon dioxide pressure is to reflect the observation that J-13 well water appears to be in equilibrium with above-atmospheric carbon dioxide levels (Yang et al. 1996, Table 7).

3.1.7 It is assumed that the thermodynamic behavior of hafnium (Hf) can be treated as if it were zirconium ( $\mathrm{Zr})$. The rationale for this assumption is the extreme similarity of the chemical behaviors of the two elements (Latimer 1952, p. 272). Thermodynamic data for many important $\mathrm{Hf}$ solids and aqueous species are lacking; thus, $\mathrm{Zr}$ was substituted for Hf in the calculation. This assumption is referenced in Section 6.3.1.

3.1.8 It is assumed that the HLW glass density is $2.85 \mathrm{~g} / \mathrm{cm}^{3}$. The rationale for this assumption is that as the HLW glass properties have not been finalized, there is some uncertainty in the HLW glass density. The value being used is conservative as it is near the maximum of the accepted range (Baxter 1988, Figure 2 and pp. 54-57). This assumption is used in Section 2.

\subsection{FAR-FIELD ACCUMULATION OF FISSILE MATERIAL}

The assumptions listed in this subsection are used throughout Section 7.

3.2.1 It is assumed that the effluent from the WP is not chemically affected by its contact with the invert when precipitation in the fracture system is considered. The rationale for this assumption is that it is conservative for fracture precipitation because no fissile material is lost in the invert, and all of the fissile material is available to be precipitated in the fractures underneath the drift. In this case, there is no accumulation in the invert. No processes in the invert could change the chemistry of the solution in such a way as to reduce the potential for fissile deposition in the rock below the invert. This includes $\mathrm{Eh}$ and $\mathrm{pH}$ as well as loss of fissile material in the invert. This assumption was made to maximize the mass of actinides available for deposition and to take into account a possible invert shortcut.

3.2.2 It is assumed that solutes do not diffuse into the rock matrix. The rationale for this 
assumption is that deposits are likely to plug small pores responsible for matrix diffusion. This will happen at early times preventing a significant quantity of radionuclides from diffusing in the matrix.

3.2.3 It is assumed that all the fractures within the footprint area beneath the WP are conductive to water, that they all have the same constant aperture, and that there is no channeling in the fracture planes. The rationale for the first part of this assumption is that connectivity of fractures is high (CRWMS M\&O 2001d, Section 6.10). The rationale for the second part of the assumption is that if it were not the case, the largest fracture(s) would take most of the flow according to the cubic law (Domenico and Schwartz 1990, pp. 86-87). The resulting mineralization would be less compact. The rationale for the third part of the assumption is similar to that for the second, i.e., channeling will lead to a less compact mineralization shape. This assumption is referenced in Section 7.2.1.1.

3.2.4 It is assumed that the accumulation envelope is cone-shaped (Figure 8-2) and that the actinide density is constant by layer. The rationale for this assumption is that as dilution progresses, the reactive domain (region) encompasses more and more rock volume because of conservation of mass. Because of the linear dimension of the drift, a wedge-shaped accumulation could have been promoted. It is, however, more appropriate to use the more conservative cone-shaped accumulation domain because the water deflected by the WP and drip shield system also brings mixing parallel to the drift.

3.2.5 It is assumed that the depth of dilution is 10 meters in all cases independent of infiltration rate, focusing factor, or fracture saturation. The rationale for this assumption is that it is conservative (CRWMS M\&O 2001b, Section 5.3.3). This assumption is referenced in Section 7.2.1.1.

3.2.6 It is assumed that, in the equivalent fracture system, mineral accumulation occurs evenly over the surface area open to deposition. This assumption applies both to lithophysal cavities although accumulation is more likely to happen at the bottom and to fractures where only large fractures are likely to receive dome mineralization. The rationale for this assumption is that it is conservative from a criticality standpoint. This assumption is not applied when a single lithophysae is considered. It is also assumed that a lithophysae is intersected by only one fracture and that all lithophysae have the same size. To achieve that effect which maximizes the equivalent fracture intensity, it is conservatively assumed that the longest dimension of a lithophysal cavity is 1/4th of the fracture spacing but still that all lithophysae are cut by fractures. The implication of this representation is that the higher the fracture intensity, the smaller the lithophysae.

3.2.7 It is assumed that in the stand-alone lithophysae representation, the dilution of the effluent WP water by the resident water is directly and linearly a function of the local fracture intensity. The rationale for this assumption is that, on average, the amount of water seeping into a lithophysal cavity increases with the fracture intensity. Because 
all fractures are assumed to have the same aperture (Assumption 3.2.3), they carry the same water flux. Dilution is then a linear function of the fracture intensity. Few fractures are active, and some may carry more water than others. This assumption is referenced in Section 7.2.1.3.

3.2.8 It is assumed that the dilution ratio can be used as a surrogate for the fracture saturation. The main mechanism for actinide precipitation is dilution, i.e., the represented volume keeps increasing. The rationale for this assumption is that, when starting from a known saturation, a known increase in the flux (as given by the dilution ratio) yields a unique higher saturation (CRWMS M\&O 2001b, Figure 5-13).

\subsection{CRITICALITY OF FAR-FIELD ACCUMULATION OF FISSILE MATERIAL}

The assumptions listed in this subsection are used throughout Section 8.

3.3.1 It is assumed that the plutonium in the ceramic is $100 \%{ }^{239} \mathrm{Pu}$. The rationale for this assumption is that it is conservative (highest possible content of fissile material).

3.3.2 The tuff matrix, fractures, and lithophysae are assumed to be fully saturated for criticality evaluations. The rationale for this assumption is that episodic fully saturated conditions are possible and conservative from moderation point of view.

3.3.3 Modern climate is assumed for calculating the seepage probability. The rationale for this assumption is that the modern climate is the most likely to give the 1 to 20 liters/year seepage rate (CRWMS M\&O 2001b, Table5-21) that is the worst case for getting a sufficiently high $\mathrm{pH}$ to get a large source term. This assumption is referenced in Section 8.4.1.3.

3.3.4 The waste package is assumed to be breached immediately after emplacement. The rationale for this assumption is that it is conservative since it allows for the least decay of ${ }^{239} \mathrm{Pu}$ to the less neutronically active ${ }^{235} \mathrm{U}$. Thus, a higher ${ }^{239} \mathrm{Pu}$ to ${ }^{235} \mathrm{U}$ ratio will lead to higher k-effective (effective neutron multiplication factor, $\mathrm{k}_{\mathrm{eff}}$ ).

3.3.5 In evaluating criticality, the fissile material is assumed to be uniformly distributed throughout the horizontal disk-shaped layer. The rationale for this assumption is that it is conservative. For any given amount, and density, of fissile material, the homogeneous distribution will have a higher $\mathrm{k}_{\mathrm{eff}}$ than the distribution with the fissile material limited to discrete fractures. This is a conservative expediency to overcome the problem that the actual spatial distribution of fractures is unknown.

3.3.6 The criticality limit is assumed to be unity. The rationale for this assumption is that this is a conservative probability calculation that takes into account all uncertainties and all probabilities associated with the evaluated system. 
3.3.7 Only minerals containing fissile materials are represented in the criticality calculations. The rationale for this assumption is that it is conservative to neglect non-fissile minerals since their presence would dilute the fissile material and increase parasitic neutron absorption.

3.3.8 The highest enrichment of ${ }^{235} \mathrm{U}$ in any of the layers is assumed for all the layers in the fracture and equivalent fracture accumulation cases. The rationale for this assumption is that it is conservative. 


\section{QUALITY ASSURANCE REQUIREMENTS}

This study is encompassed by the activity evaluation "Plutonium Disposition" that is part of the Technical Work Plan for: Plutonium Disposition Work Packages (CRWMS M\&O 2000a), prepared in accordance with AP-2.21Q, Quality Determination and Planning for Scientific, Engineering, and Regulatory Compliance Activities. The result of that evaluation was that the Plutonium Disposition activity is subject to the Quality Assurance Requirements and Description (DOE 2000).

This technical report was prepared in accordance with AP-3.11Q, Technical Reports, and reviewed in accordance with AP-2.14Q, Review of Technical Documents. The External Criticality Risk of Immobilized Plutonium Waste Form in a Geologic Repository technical report does not serve as a primary source for data or software described in the supporting calculations; this function is provided by the calculations themselves. The calculations supporting this technical report were prepared in accordance with AP-3.12Q, Calculations, AP-3.15Q, Managing Technical Product Inputs, and AP-3.14Q, Transmittal of Input. The control of the electronic management of data was evaluated in accordance with AP-SV.1Q, Control of the Electronic Management of Information, and software managed in accordance with AP-SI.1Q, Software Management. Control of the electronic management of data has been accomplished in accordance with the controls specified in the technical work plan: Plutonium Disposition Work Packages (CRWMS M\&O 2000a, Section 13). 


\section{INTENTIONALLY LEFT BLANK}




\section{SOFTWARE USED TO SUPPORT ANALYSES}

This Technical Report includes the results from software codes and routines used in the supporting calculations, but these software products were not used in the development of this report. The following statements regarding these software products are made for information only. Software products used in the development of the information used in this report are limited to the EQ3/6 software package, the PHREEQC software package, and the MCNP software package.

\section{$5.1 \quad \mathrm{EQ3} / 6$}

The software package, "EQ3/6 V7.2b", Computer Software Configuration Item (CSCI): UCRLMA-110662 and "EQ6 Version 7.2bLV", Software Tracking Number (STN): 10075-7.2bLV-00 (LLNL 1999 and CRWMS M\&O 1999e, respectively), was approved for QA work by LLNL and qualified under the AP-SI.1Q procedure. The software was obtained through Configuration Management. It is appropriate for use in the calculations summarized in this report and has been used within the range of parameters for which the software has been verified.

The major components of the EQ3/6 package include EQ3NR, a speciation-solubility code, EQ6 (CRWMS M\&O 1999e), a reaction path code which represents water/rock interaction or fluid mixing in either a pure reaction progress mode or a time mode; EQPT, a data file preprocessor (Daveler and Wolery 1992); EQLIB, a supporting software library; and several (> 5) supporting thermodynamic data files. EQ6 7.2bLV is the only version of EQ6 capable of incorporating radioactive decay.

The implementation of the Solid-Centered Flow-Through Mode is covered by the Software Change Request (SCR) LSCR198, and the Software Qualification Report (SQR) (CRWMS M\&O 1998c) for Media Number 30084-M04-001. The version 7.2bLV of EQ6 was developed under software activity number LV-1999-008. The software validation is documented in the software validation report ([VTR] CRWMS M\&O 2000e) that has been reviewed and approved.

The EQ3/6 programs have been used within the range of parameters for which they have been verified and are, therefore, appropriate for the application. The software was used within its range of validation. However, some runs simulated periods of high ionic strength (1 to 4). While EQ6 is capable of handling high ionic strengths, there is no Yucca Mountain Project (YMP)-qualified thermodynamic database with corrections for high ionic strength. To address this issue, several sensitivity tests were performed using other thermodynamic databases that have corrections for high ionic strength (CRWMS M\&O 2000j, Section 5.1.2). The results of calculations relating to these tests have shown that calculations at high ionic strength, using the "data0.ymp" database, overestimate the solubility of $\mathrm{Pu}$ and $\mathrm{U}$, which is conservative with respect to release from the waste package and external accumulations of these elements.

\subsection{PHREEQC}

The software package, "PHREEQC V2.0", STN: 10068-2.0-00 (CRWMS M\&O 1999c) has been qualified under the AP-SI.1Q procedure under the Software Activity Number LV-1999-002 (CRWMS M\&O 1999c). The software validation is documented in the VTR (CRWMS M\&O 
1999b) that has been reviewed and approved. The software was obtained through Configuration Management. It is appropriate for use in the calculations summarized in this report and has been used within the range of parameters for which the software has been verified.

PHREEQC Version 2.0 PC contains capabilities such as speciation-solubility and kinetically controlled reaction pathway features, which are found in many geochemical software packages, but also includes surface complexation, ion exchange, absorption and solid solutions, and a very versatile treatment of rate laws. In addition, PHREEQC has transport features with handling of dispersion and diffusion in a double-porosity medium. It also has inverse representation capabilities. However, unlike EQ6, which is a similar geochemical representation program, PHREEQC supports only the use of the Davies or B-dot equations for the activity coefficients. The thermodynamic database used by PHREEQC is a direct transcription of the EQ6, translated into a PHREEQC-readable format.

PHREEQC representations the consequences of reacting an aqueous solution with a set of reactants according to thermodynamic laws. It can also include very complex kinetics laws through a BASIC interpreter coupled to the program. PHREEQC handles advective transport by moving aqueous solutions from one cell to the next, allowing the contents of each cell to reach equilibrium (or not) with the solids and surface features present in the cell (CRWMS M\&O 1999d). Diffusion and dispersion are handled by mixing the contents of cells in proportion to the diffusion (or dispersion) parameters. It is restricted to a constant time step, unlike the dynamic time stepping of EQ6.

\subsection{MCNP}

The software package (including the associated cross section files), "MCNP Version 4B2LV" CSCI: 30033 V4B2LV (CRWMS M\&O 1998e), is a qualified software package. The software validation is documented in the SQR (CRWMS M\&O 1998b) that has been reviewed and approved. The software was obtained through Configuration Management. It is appropriate for use in the calculations summarized in this report and has been used within the range of parameters for which the software has been verified.

MCNP Version 4B2LV is a General Monte Carlo N-Particle Transport Code (Briesmeister 1997) that evaluates the $k_{\text {eff }}$ for a variety of geometric configurations with neutron cross sections for elements and isotopes described in the Evaluated Nuclear Data File version B-V. In particular, the software is used to calculate the $\mathrm{k}_{\text {eff }}$ of the far-field configurations (external to the WP) of fissile material. 


\section{DEGRADATION ANALYSES}

\subsection{DEGRADATION ANALYSIS METHODOLOGY}

The degradation analysis (CRWMS M\&O 2001a) consists of using the EQ3/6 geochemistry code to calculate the amount and composition of the solid degradation products and the composition of the solution in the waste package as a function of time. The amount and composition of solids and solutions are important for the evaluation of internal criticality. The solution composition is also important for the evaluation of potential external accumulation of the fissile isotopes, ${ }^{239} \mathrm{Pu}$ and ${ }^{235} \mathrm{U}$, after their possible removal from the waste package as the solution flows (or overflows) out of the waste package. This flow out of the waste package is viewed as the source term for the external accumulation analysis discussed in Section 7.

The method used for this calculation involves the following steps:

- Use of the EQ3/6 reaction-path code for tracing the degradation of the waste package internal components. The software estimates the concentrations remaining in the aqueous solution and the composition of the precipitated solids. For this purposethe "solid-centered flow-through" mode of EQ6 is used. In this mode, an increment of aqueous "feed" solution is added continuously to the waste package system, and a like volume of the existing solution is removed, simulating a continuously-stirred tank reactor.

- Determination of fissile material concentrations in solution as a function of time (from the output of EQ6 simulated reaction times up to $6 \cdot 10^{5}$ years).

- Calculation of the amount of fissile material released from the waste package as a function of time, based on the waste package solution concentration of fissile material and the assumed rate of outflow that is the same as the inflow drip rate.

The inputs to EQ3/6 calculations include material compositions, material amounts, surface areas, and reaction rates of the various components of Pu-ceramic waste packages. The input also includes environmental parameters such as the composition of incoming water together with a rate of influx to the waste package that corresponds to suitably chosen percolation rates into a drift and drip rate into a waste package. The EQ6 output provides the results of the chemical degradation calculations for the waste package, or components thereof. The results include the compositions and amounts of solid products and of elements dissolved in solution for a selected number of cases.

All of the past degradation calculations for the immobilized plutonium waste form (CRWMS M\&O 1999a; CRWMS M\&O 1998a; and CRWMS M\&O 2000j) used the maximum of five Pubearing canisters per waste package. As discussed in Section 1, transportation safeguards limiting the number of Pu-bearing canisters per shipment are likely to encourage an emplacement policy of only one Pu-bearing canister per waste package. Therefore, the degradation calculation now includes a nominal strategy of one Pu-bearing canister per package, with evaluation of criticality for two Pu-bearing canisters per package, to account for the possibility of human error (CRWMS M\&O 2001a, Section 1). 


\subsection{DEGRADATION SCENARIOS CONSIDERED FOR THIS STUDY}

The EQ6 scenarios evaluated represent conservative assessments of solubility and transport of criticality control materials ( $\mathrm{Gd}$ and $\mathrm{Hf}$, the neutron absorbers) and fissile materials (i.e., $\mathrm{U}$ and $\mathrm{Pu}$ compounds) in the waste package. The proposed criticality control materials are incorporated into the ceramic. Upon degradation of the ceramic, the $\mathrm{Hf}$ is expected to form insoluble Hf oxides, which will remain in the waste package. Degradation of the ceramic is also expected to yield varied amounts of (1) aqueous (dissolved) $\mathrm{Gd}$ and (2) a solid Gd phosphate, possibly $\mathrm{GdPO}_{4} \cdot 10$ $\mathrm{H}_{2} \mathrm{O}$ or $\mathrm{GdPO}_{4} \cdot \mathrm{H}_{2} \mathrm{O}$. Gadolinium phosphate is sparingly soluble in neutral solutions, though the solubility does increase at low and high pH (CRWMS M\&O 1998d, Section 5.3.1). Formation of $\mathrm{GdPO}_{4} \cdot 10 \mathrm{H}_{2} \mathrm{O}$ is expected to be the controlling solid phase because of the amount of phosphate from degrading stainless steel. Dissolution of solid Gd carbonates and phosphates, at high $\mathrm{pH}$, is also enhanced by dissolved carbonate. Uranium and plutonium are also quite soluble in the alkaline, carbonate-rich solutions produced when HLW glass degrades. Thus, the most conservative EQ6 scenarios are those that yield high $\mathrm{pH}$, particularly high $\mathrm{pH}$ with high dissolved carbonate.

Low-pH conditions (of greatest concern for Gd loss) are likely to occur when the stainless steel of the inner sleeve degrades after the complete degradation of the HLW glass. In this manner the alkalinity from the glass degradation will be completely flushed out of the package by the time the ceramic starts degrading. The result is that during the degradation of the Pu-bearing ceramic the degrading stainless steel can produce a maximum $\mathrm{pH}$ lowering (unneutralized by the glass alkalinity). Under such circumstances the degradation can be divided into two stages. The first stage involves an early breach of the 304L stainless steel canisters holding the HLW glass, followed by fast degradation of the HLW glass and removal of the alkaline components during a period of relatively high drip rate. In the second stage, the 304L cans holding the ceramic are allowed to breach, exposing some portion of the Pu-U-Gd-Hf-ceramic to acid conditions. To keep the $\mathrm{pH}$ low, the drip rate must be reduced for the second stage. It should be noted that the twostage runs are somewhat unrealistic because an extremely high glass degradation rate must be assumed in order that all the glass be degraded before any significant breach of the thin $304 \mathrm{~L}$ cans. Nevertheless, a few two-stage runs were considered for conservatism (with respect to possible loss of $\mathrm{Gd}$ ) to test the sensitivity of the system to sustained, low-pH conditions capable of dissolving $\mathrm{GdPO}_{4} \cdot \mathrm{H}_{2} \mathrm{O}$ with the stainless steel inner sleeve (YMP 2000, Section 3.3.1).

Thus, the reaction scenarios can be divided into two general categories. The first category comprises single-stage cases in which all reactants (steels, HLW glass, and fissile materials) are exposed simultaneously to the water in the waste package. This will produce the highest $\mathrm{pH}$ (from degrading glass alkalinity) while the ceramic is degrading, so it is most conservative with respect to solubility and release of fissile material for external criticality. Because the reaction rates of the materials in the waste package may vary greatly, all materials do not necessarily degrade simultaneously. To reflect this uncertainty, a range of degradation rates used in the EQ6 calculations.

The second category comprises two-stage runs. In the first stage, the A516 outer web (basket) and the glass pour canisters (HLW glass and 304L steel) are first exposed to water, until the HLW glass is completely degraded and its alkalinity largely flushed out of the system. The first stage is 
actually run twice; once up to approximately three times as long as is required to degrade the HLW glass, in order to locate the true $\mathrm{pH}$ minimum; and it is run a second time, just to the commencement of the low-pH plateau, to create an EQ6 pickup file for the second stage. This repetitive process ensures that the maximum acidity (lowest $\mathrm{pH}$ ) will be achieved in the second stage. In the second stage, the 304L cans, magazines, rack, and Pu-ceramic disks are the primary reactants. Thus, the two-stage runs produce a "conservative" condition of high acidity, by degrading the HLW glass rapidly, before all the acid-producing steel is degraded. The early HLW glass degradation and flushing requires very high HLW glass degradation rates and representation of possible extensive fracturing as a multiplied surface area (both possible but highly unlikely).

The degradation study included 12 single-stage and 4 two-stage runs, with varied combinations of steel, HLW glass, and ceramic degradation rates and water fluxes. Seven of the cases were reruns of former cases (CRWMS M\&O 1999a). These were Cases 3, 5, 8, 10, 14, 21, and 22 of that document, and the same designations have been kept for convenience of comparison; all have five $\mathrm{Pu}$-bearing canisters and new degradation rates. A summary of the conditions for the single-stage runs is given in Table 6-1 (CRWMS M\&O 2001a, Table 5-8) and for the multiple-stage runs in Table 6-2 (CRWMS M\&O 2001a, Table 5-9). Nine of the cases tested the sensitivity to (1) the number of $\mathrm{Pu}$ canisters (Cases s1, s2, s3, s7, s8), (2) the combination of degradation rates to maximize $\mathrm{Pu}$ and $\mathrm{U}$ loss from the waste package (Cases s4, s4b, s5), and (3) the formation of $\mathrm{GdPO}_{4} \cdot 10 \mathrm{H}_{2} \mathrm{O}$ versus $\mathrm{GdPO}_{4} \cdot \mathrm{H}_{2} \mathrm{O}$ (Case s6).

Table 6-1. Summary of Single-Stage EQ6 Cases for Pu-Ceramic Waste Package

\begin{tabular}{|c|c|c|c|c|c|}
\hline \multirow{2}{*}{$\begin{array}{c}\text { Case } \\
\text { Number }^{a}\end{array}$} & \multicolumn{3}{|c|}{ Rates of Degradation for: } & \multirow{2}{*}{$\begin{array}{l}\text { Water Drip } \\
\text { Rates }\left(\mathrm{m}^{3} / \mathrm{y}\right)\end{array}$} & \multirow{2}{*}{ Comments $^{b}$} \\
\hline & Steel & Glass & Pu Ceramic & & \\
\hline 3 & Average & Average & High & 0.0015 & 5 Pu canisters \\
\hline 5 & Average & Average & Average & 0.015 & 5 Pu canisters \\
\hline 8 & Average & High & High & 0.0015 & 5 Pu canisters \\
\hline 10 & Average & High & Average & 0.015 & 5 Pu canisters \\
\hline 14 & High & Average & High & 0.15 & 5 Pu canisters \\
\hline s1 & Average & Average & High & 0.0015 & 1 Pu canister \\
\hline s2 & Average & Average & High & 0.015 & 1 Pu canister \\
\hline s3 & Average & Average & High & 0.0015 & 2 Pu canisters \\
\hline s4 & Low & High & Very High & 0.0015 & 2 Pu canisters \\
\hline$s 4 b$ & Low & High & Very High & 0.0015 & 2 Pu canisters \\
\hline s5 & Very Low & $\begin{array}{l}\text { Moderately } \\
\text { High }\end{array}$ & Very High & 0.0015 & 2 Pu canisters \\
\hline s6 & Average & Average & High & 0.0015 & $\begin{array}{l}5 \mathrm{Pu} \text { canisters, } \\
\mathrm{GdPO}_{4} \cdot \mathrm{H}_{2} \mathrm{O} \text { is } \\
\text { formed }\end{array}$ \\
\hline
\end{tabular}

NOTES: ${ }^{a}$ Cases numbers beginning with $S$ are sensitivity cases developed for this study. Those without $S$ are re-runs from the previous study (with new material and environmental parameters).

${ }^{b}$ In the single stage runs, hematite was the iron oxide allowed to form. 
Table 6-2. Summary of Multiple-Stage EQ6 Cases for Pu-Ceramic Waste Package

\begin{tabular}{|c|c|c|c|c|c|c|}
\hline \multirow{2}{*}{$\begin{array}{c}\text { Case } \\
\text { Number }^{\mathrm{a}}\end{array}$} & \multicolumn{3}{|c|}{ Rates of Degradation for: } & \multirow{2}{*}{$\begin{array}{c}\text { Water Drip } \\
\text { Rates }\left(\mathrm{m}^{3} / \mathrm{y}\right)\end{array}$} & \multirow{2}{*}{ Comments } & \multirow{2}{*}{ Fe Oxide } \\
\hline & Steel & Glass & Pu Ceramic & & & \\
\hline $21(a)$ & High & High & No Ceramic & 0.5 & 5 Pu canisters & Hematite \\
\hline 21 (b) & High & $\begin{array}{l}\text { No Glass } \\
\text { Present }\end{array}$ & Average & 0.015 & 5 Pu canisters & Hematite \\
\hline $22(a)$ & High & High & No ceramic & 0.5 & 5 Pu canisters & Goethite \\
\hline 22(b) & High & $\begin{array}{l}\text { No Glass } \\
\text { Present }\end{array}$ & Average & 0.015 & 5 Pu canisters & Goethite \\
\hline s7(a) & High & High & No ceramic & 0.5 & 1 Pu canister & Goethite \\
\hline s7(b) & High & $\begin{array}{l}\text { No Glass } \\
\text { Present }\end{array}$ & Average & 0.015 & 1 Pu canister & Goethite \\
\hline s8(a) & High & High & No ceramic & 0.5 & 2 Pu canisters & Goethite \\
\hline s8(b) & High & $\begin{array}{l}\text { No Glass } \\
\text { Present }\end{array}$ & Average & 0.015 & 2 Pu canisters & Goethite \\
\hline
\end{tabular}

NOTE: ${ }^{a}$ The symbol (a) indicates the first stage (which has only glass and steel degrading), and the symbol (b) indicates second stage (which has no glass left).

\subsection{DEGRADATION ANALYSIS RESULTS}

\subsubsection{Comparison of Results for Nominal Cases}

The nominal case results can be compared with the results from the previous calculation (CRWMS M\&O 1999a, Table 6-1) in terms of the loss of the neutron absorber, Gd, and fissile materials, $\mathrm{Pu}$ and U. This comparison is shown in Table 6-3 (CRWMS M\&O 2001a, Table 6-1). 
Table 6-3. Summary of Gd, Pu, and U Losses for the Primary EQ6 Cases

\begin{tabular}{|c|l|l|l|l|l|}
\hline Case ID & Years & \%Gd Loss & \%Gd Loss $^{\mathrm{b}}$ & \%Pu \& U Loss $^{\mathrm{a}}$ & $\begin{array}{c}\text { Moles Pu } \\
\text { Discharged }^{\mathbf{i}}\end{array}$ \\
\hline 3 & $6.35 \mathrm{E}+05$ & 0.24 & $20.45^{\mathrm{c}}$ & 100.0 & 52 \\
\hline 5 & $6.34 \mathrm{E}+05$ & 0.22 & $8.33^{\mathrm{d}}$ & 39.4 & 7.6 \\
\hline 8 & $6.34 \mathrm{E}+05$ & 0.11 & $0.02^{\mathrm{c}}$ & 81.9 & 61 \\
\hline 10 & $9.98 \mathrm{E}+05$ & 0.51 & $17.06^{\mathrm{e}}$ & 33.0 & 9.5 \\
\hline 14 & $8.13 \mathrm{E}+04$ & 0.53 & $49.01^{\mathrm{f}}$ & 6.0 & 6.2 \\
\hline 21 & $3.17 \mathrm{E}+05$ & 0.01 & $0.07^{\mathrm{9}}$ & 1.2 & 0.9 \\
\hline 22 & $3.17 \mathrm{E}+05$ & 0.07 & $0.07^{\mathrm{h}}$ & 1.2 & 0.9 \\
\hline
\end{tabular}

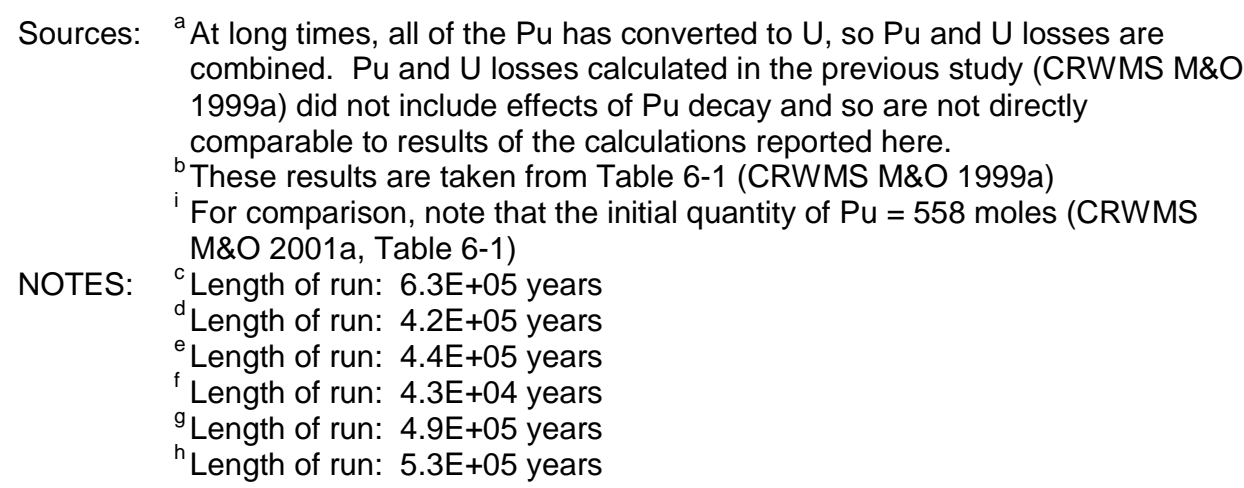

Table 6-3 shows that in all of the cases, the Gd loss ( $3^{\text {rd }}$ column of Table 6-3) for this study was less than $1 \%$, unlike the previous study in which the cases 3,10, and 14 showed significant $\mathrm{Gd}$ loss. The principal reason for the reduced Gd loss in the EDA II design of this study is the increased phosphorus levels introduced by degradation of the $316 \mathrm{~L}$ stainless steel inner waste package barrier. (Recall that the previous VA design had the inner barrier made of the very corrosion resistant Alloy 22 that was assumed to have negligible effect on the waste package chemistry (CRWMS M\&O 1999a, Assumption 3.1.7.) Even though corrosion of the inner barrier of the EDA II design waste package is expected to lower the $\mathrm{pH}$ as a result of the chromic acid from the oxidation of the chromium as it is released from the stainless steel (316L), the phosphorus oxidized to phosphate as it is released from the steel will capture the Gd in $\mathrm{GdPO}_{4}$, which has a much lower solubility than the gadolinium solids that would otherwise be formed. The very low loss of Gd shown in Table 6-3 confirms the predictions of the impossibility of internal criticality given in previous report (CRWMS M\&O 2000k, Section 8.2.4).

With this confirmation of the impossibility of internal criticality, the remainder of this report can focus on the possibility of external accumulation of a critical mass. A significant parameter for external accumulation is the total amount of $\mathrm{Pu}$ released from the waste package, which is given in the last column of Table 6-3. The most significant releases are for cases 3 and 8, but even those are only $10 \%$ of the initial total of 558 moles $\mathrm{Pu}$ (for five Pu-bearing canisters). It is shown in the following section that the unique conditions of the sensitivity cases resulted in much larger $\mathrm{Pu}$ releases from the waste package, even though they had only $40 \%$ of the initial Pu loading (two canisters instead of five). For this reason the source term for external accumulation (and possible criticality) was taken only for the sensitivity cases, as explained in the following section. 


\subsubsection{Sensitivity Analyses}

In addition to the nominal comparison cases (EDA II versus VA design), a series of sensitivity cases were used to evaluate the effects of changes in number of Pu-bearing canisters, drip rate, and corrosion rates of the steel, glass, and ceramic waste form. An additional sensitivity run was made to determine the impact of using $\mathrm{GdPO}_{4} \cdot \mathrm{H}_{2} \mathrm{O}$ as the solubility controlling phase in Case 3 instead of $\mathrm{GdPO}_{4} \cdot 10 \mathrm{H}_{2} \mathrm{O}$ (Case s6).

The basic chemistry (except for the quantity of Pu and $\mathrm{U}$ ) of the system is essentially unaffected by change in the amount of Pu ceramic present in the WP as it has a small affect on central chemical parameters such as $\mathrm{pH}, \mathrm{Eh}$, and ionic strength. The quantity of these elements in the solid degradation products is, however, proportional to the number of Pu-bearing canisters, as indicated in Figure 6-1, which compares the quantities of $\mathrm{Gd}$ and Pu over time for cases s1, s3, and 3, that have, respectively, one, two, and five Pu-bearing canisters and are identical in all other respects (CRWMS M\&O 2001a, Figure 6-16).

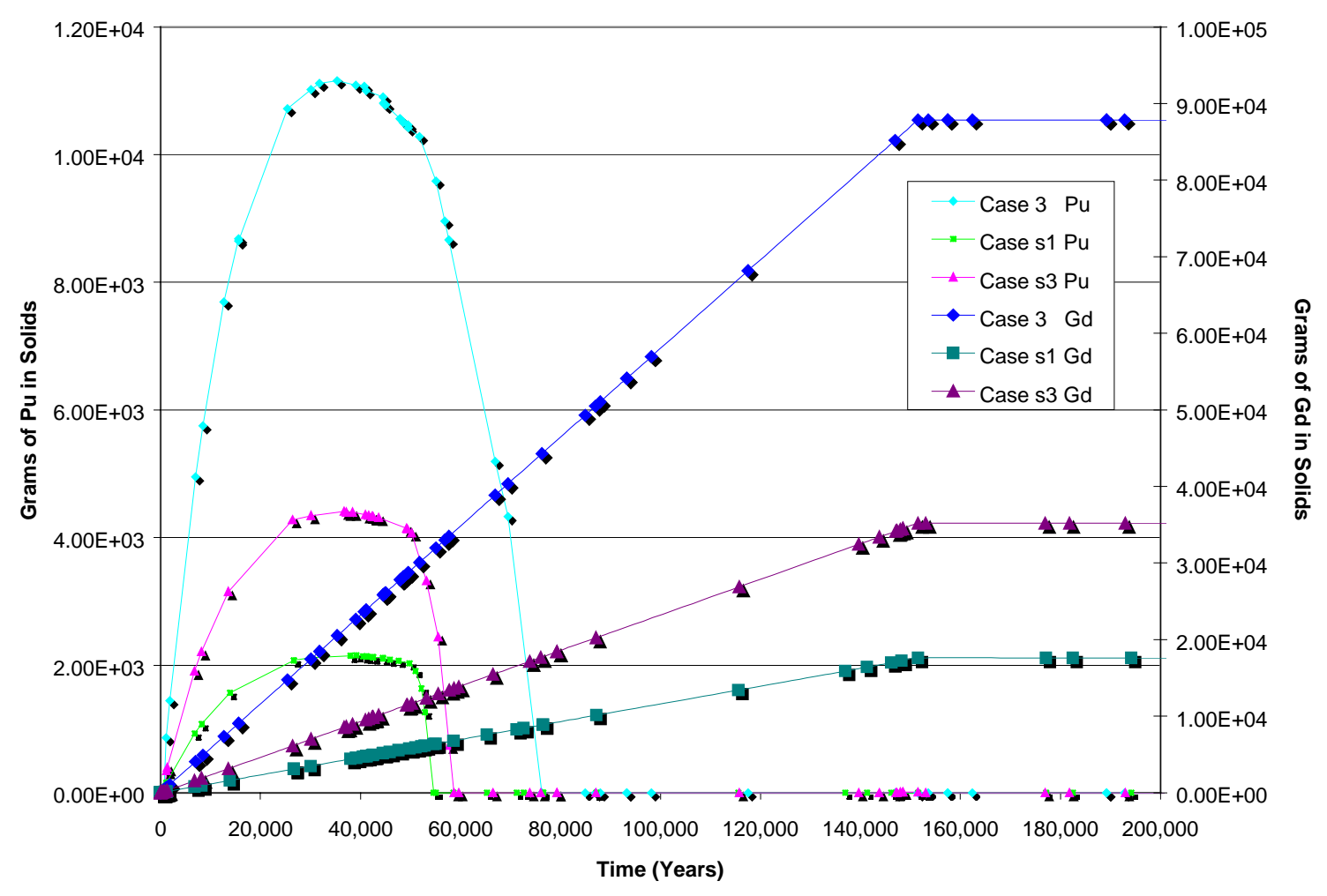

Figure 6-1. Mass of Pu and Gd in Minerals in Waste Package 
The material loss results for all the sensitivity cases are summarized in Table 6-4 (CRWMS M\&O 2001a, Table 6-16).

Table 6-4. Result of Sensitivity Analyses

\begin{tabular}{|c|c|c|c|c|c|}
\hline Case ID & $\begin{array}{c}\text { Number Pu } \\
\text { Canisters }\end{array}$ & Years & \%Gd Loss & $\begin{array}{c}\text { Initial } \\
\text { Moles Pu }\end{array}$ & $\begin{array}{c}\text { Moles Pu } \\
\text { Discharged }\end{array}$ \\
\hline s1 & 1 & $6.34 \mathrm{E}+05$ & 0.05 & 112 & 14 \\
\hline $\mathrm{s} 2$ & 1 & $3.97 \mathrm{E}+05$ & 0.21 & 112 & 12 \\
\hline $\mathrm{s} 3$ & 2 & $6.34 \mathrm{E}+05$ & 0.27 & 224 & 27 \\
\hline s4 & 2 & $6.34 \mathrm{E}+05$ & 33.49 & 224 & 116 \\
\hline s4b & 2 & $6.34 \mathrm{E}+05$ & 33.47 & 224 & 109 \\
\hline s5 & 2 & $6.34 \mathrm{E}+05$ & 0.26 & 224 & 155 \\
\hline s6 & 5 & $6.34 \mathrm{E}+05$ & 0.24 & 558 & 52 \\
\hline s7 & 1 & $4.36 \mathrm{E}+05$ & 0.15 & 112 & 0.7 \\
\hline s8 & 2 & $6.34 \mathrm{E}+05$ & 0.25 & 224 & 0.8 \\
\hline
\end{tabular}

Source: CRWMS M\&O 2001a, Table 6-16

Cases s4 and s4b show a 33\% Gd loss, which is much higher than any of the other cases run. The loss occurs at about 100,000 years after breach (CRWMS M\&O 2001a, Section 6.8.2), after nearly all of the ${ }^{239} \mathrm{Pu}$ has been discharged from the WP or has decayed to ${ }^{235} \mathrm{U}$. Therefore, the loss of $\mathrm{Gd}$ in these cases does not increase the likelihood of internal criticality. 


\subsubsection{Worst-Case Source-Term Concentrations}

Cases $\mathrm{s} 4, \mathrm{~s} 4 \mathrm{~b}$, and $\mathrm{s} 5$ are intended to represent the conditions that maximize the concentration of $\mathrm{Pu}$ in the solution flowing out of the waste package. All of these cases assume two Pu canisters in the waste package and a low drip rate. Since the Pu solubility increases at values of $\mathrm{pH}$ above 8 or 9 , these cases used degradation rates, which resulted in high $\mathrm{pH}$ values early in the run, before $\mathrm{Pu}$ has time to decay to ${ }^{235} \mathrm{U}$. The steel degradation rates were low or very low; the HLW glass degradation rate was high or moderately high; and the Pu-ceramic degradation rate was very high. The results from the cases $s 4$ and s5 are shown in Figures 6-2 and 6-3 (CRWMS M\&O 2001a, Figures 6-20 and 6-22), respectively. These cases show the maximum amount of Pu discharged from the waste package and were, therefore, the principal source terms for the external accumulation calculations discussed in Section 7.

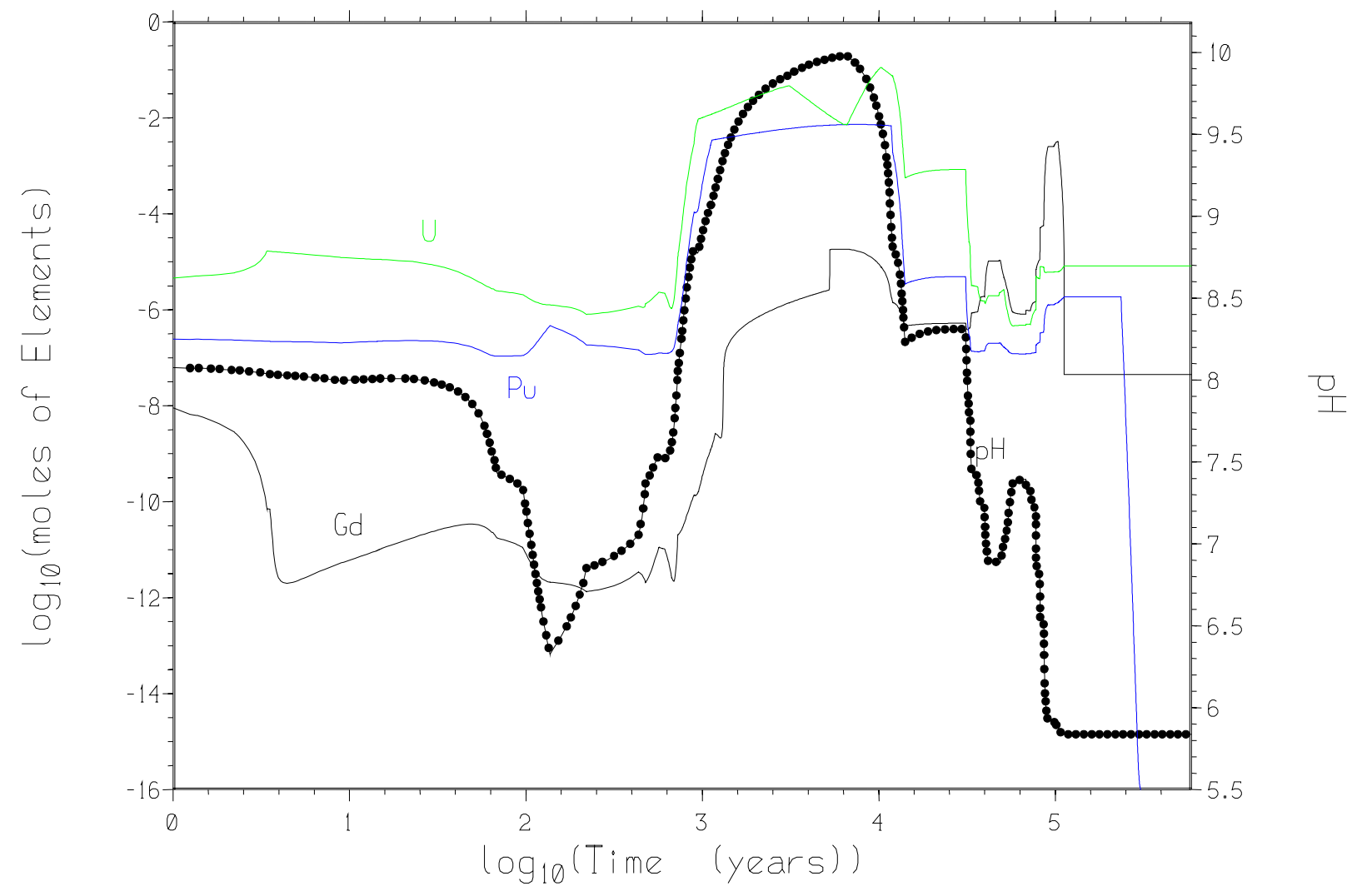

Figure 6-2. Case s4: $\mathrm{pH}$ and Total Aqueous Gd, U, and Pu

Case $\mathrm{s} 5$, is similar to case $\mathrm{s} 4$, but the degradation rate of the $316 \mathrm{~L}$ inner sleeve was taken to be lower by a factor of ten. In addition, the degradation rate of the HLW glass was reduced from a high value to a moderately high value, so that the degradation of the HLW glass ended at the same time as the $\mathrm{Pu}$ ceramic. This slower glass degradation rate resulted in peak $\mathrm{pH}$ lasting longer $(\log [$ time $]=4.2$, rather than 4.0 in Case s4). The effect on the Pu concentration was a delayed peak, at an increased concentration, which led to a larger amount of Pu discharged. 


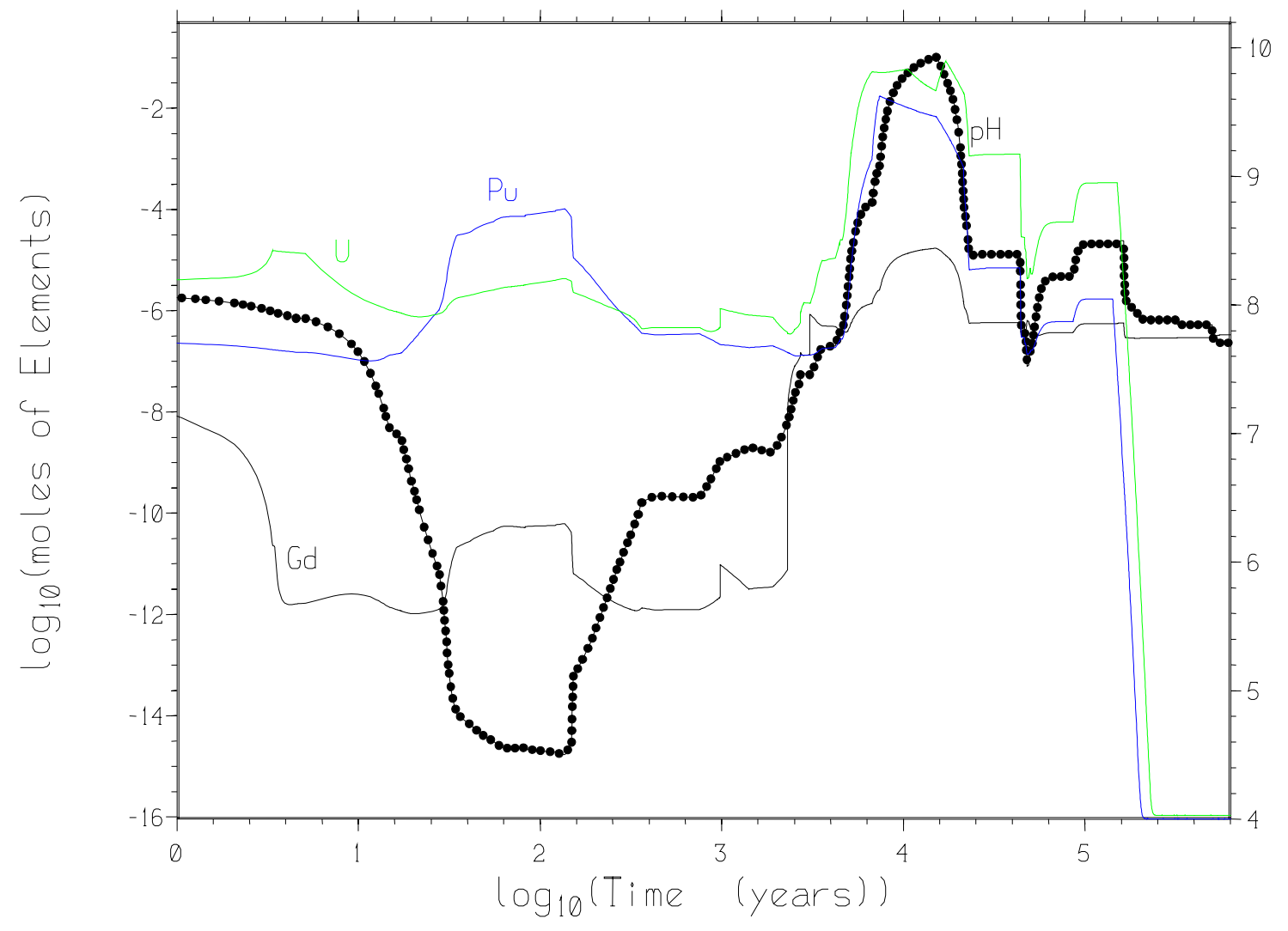

Figure 6-3. Case s5: $\mathrm{pH}$ and Total Aqueous Gd, U, and Pu

\subsubsection{Calculation of ${ }^{235} \mathrm{U}$ Enrichment Fraction in the Effluent}

The decay of ${ }^{239} \mathrm{Pu}$ to ${ }^{235} \mathrm{U}$ (with half-life of 24,100 years) will generally reduce the criticality of any accumulations since the latter has a lower fission cross section than the former. Since most of the uranium in the waste package is the non-fissile ${ }^{238} \mathrm{U}$ isotope, the ${ }^{235} \mathrm{U}$ enrichment of the source term must be calculated. However, EQ6 does not differentiate among the isotopes of U (or any other element). Because the ${ }^{235} \mathrm{U}$ enrichment varies with time for the Pu ceramic and because the enriched $U$ from the degrading Pu ceramic will be diluted by the U from the degrading HLW glass, the effluent's U concentration alone does not provide a sufficient source term for external criticality calculations. To provide the accurate source term, estimates of the U enrichment fraction (moles of ${ }^{235} \mathrm{U}$ per mole of $\mathrm{U}$ ) in the effluent were made outside of the EQ6 software. The enrichment fraction changes over time due to the differing degradation rates of the HLW glass and the $\mathrm{Pu}$ ceramic. The enrichment fraction is calculated as described below for three phases of $\mathrm{Pu}$ ceramic and HLW glass degradation.

Phase 1-The Pu ceramic and HLW glass are degrading simultaneously (although at different rates, which may be constant in time or may be $\mathrm{pH}$ dependent). The enrichment fraction of the uranium in solution is calculated from the quantities of fissile 
uranium and total uranium that are entering the effluent solution from the simultaneously degrading HLW glass and Pu ceramic during each time step, as follows:

$$
\left(M_{G} * E_{G}+M_{P} * E_{P}\right) /\left(M_{G} * T_{G}+M_{P} * T_{P}\right)
$$

where $M$ is the quantity of Pu-ceramic or HLW glass degraded (moles), $E$ is the ratio of moles of ${ }^{235} \mathrm{U}$ to total moles of glass or Pu ceramic, $T$ is the ratio of moles of total $\mathrm{U}$ to total moles of glass or Pu-ceramic, subscript $G$ represents glass, and subscript $P$ represents $\mathrm{Pu}$ ceramic. This enrichment fraction is calculated for each EQ6 time step. This phase lasts until the glass is completely degraded.

Phase 2-This phase begins when the glass is fully degraded and continues until the $\mathrm{Pu}$ is fully degraded. During this phase, the majority of $U$ in solution comes from the dissolution of U-bearing minerals, with a minor contribution from the degrading Pu ceramic. During this phase the enrichment fraction is assumed to be equal to the enrichment fraction at the end of Phase 1 since the majority of the $U$ is coming from the minerals which were deposited during Phase 1.

Phase 3-This phase begins when the Pu ceramic is fully degraded and the only source of U is in the minerals or the aqueous phase. The enrichment fraction calculated at the end of Phase 1 is assumed to be the enrichment fraction at the start of this phase. Then for each time step, the enrichment fraction is determined to be:

$$
\left(\left(M_{U 235}\right)_{t-1}+\left(M_{P u \rightarrow U}\right)_{\Delta t}-\left(M_{U 235 \text { out }}\right)_{\Delta t}\right) /\left(M_{U}\right)_{t}
$$

where $\left(M_{U 235}\right)_{t-1}$ is the moles of ${ }^{235} \mathrm{U}$ in the waste package at the previous time step, $\left(M_{P u \rightarrow U}\right)_{\Delta t}$ is the moles ${ }^{235} \mathrm{U}$ created by Pu decay during the time step, $\left(M_{U 235} \text { out }\right)_{\Delta t}$ is the moles ${ }^{235} \mathrm{U}$ lost from the waste package in the effluent during the time step, and $\left(M_{U}\right)_{t}$ is total moles $\mathrm{U}$ in the waste package at the end of the time step.

Figure 6-4 (CRWMS M\&O 2001a, Figure 6-25) shows the result of applying this method to develop the uranium enrichment fraction for Case s5 for the first 30,000 years following waste package breach. For simplicity, and conservatism, the amount of $\mathrm{Pu}$ at time of breach is assumed to be equal to the $\mathrm{Pu}$ at time of ceramic formation. In other words, no credit is taken for the $43 \%$ $\mathrm{Pu}$ decay that will occur between the time of ceramic formation and the 20,000 year period to the time of earliest waste package breach (Section 1, Page 1-1). 


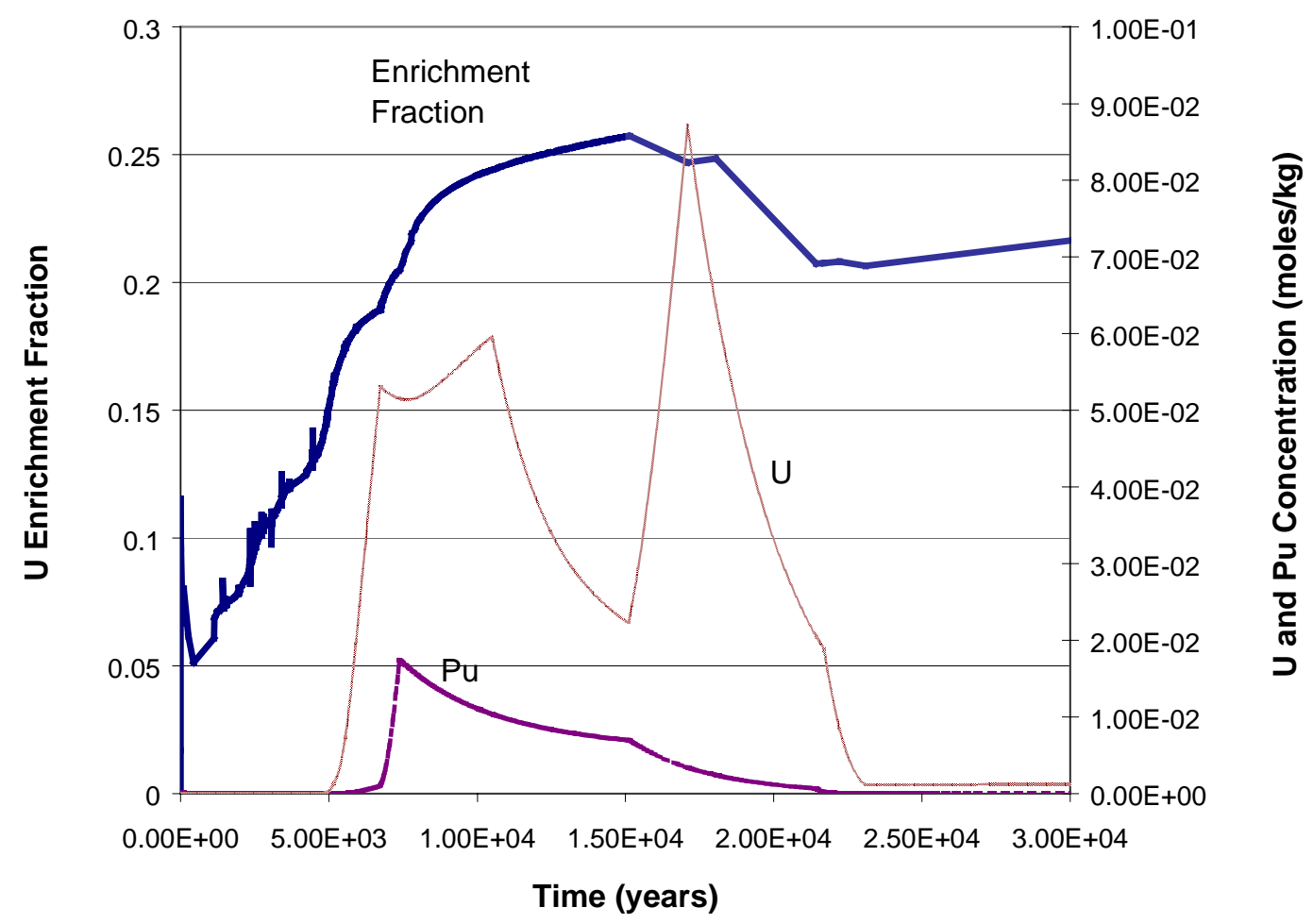

Figure 6-4. Case s5: Uranium Enrichment Fraction and Total Aqueous $U$ and Pu 


\section{INTENTIONALLY LEFT BLANK}




\section{EXTERNAL ACCUMULATION OF FISSILE MATERIAL}

\subsection{ACCUMULATION IN THE INVERT}

Criticality in the invert requires the additional accumulation mechanism of reduction of partially oxidized iron (from the partial degradation of drift structural steel) as presented in CRWMS M\&O (2000k). This mechanism is very unlikely for a number of reasons, most of which are expected to be evaluated prior to licensing to demonstrate a probability below the screening threshold. Dilution can also happen in the invert (as shown in Figure 7-1). However, the bulk of this dilution is caused by that water being diverted by the drift.

\subsection{ACCUMULATION IN THE FAR-FIELD}

Accumulation calculations of fissile material in the far-field are performed in CRWMS M\&O (2001b). The following subsections present a summary of the methodology and results.

\subsubsection{Accumulation in the Far-Field: Mechanisms}

Far-field accumulations mechanism is the likely addition of dilution of the WP egress water. Dilution leads to a shift in equilibrium leading itself to possible precipitation of actinides. Dilution of the effluent from the waste package occurs through local dilution due to water flowing around the drift (Figure 7-1) (CRWMS M\&O 2001b, Figure 5-14). When the successive engineered barriers divert the percolation flux, a "dry shadow" builds up underneath the drift (Philip et al. 1989).

As little as $0.1 \%$ of the total seepage flow could actually flow through the WP and that only after failure/breach of the drip shield. As the flow proceeds downwards, water progressively invades the dry shadow volume.

The density of the actinide accumulation depends on the open space available for precipitation. That space is the fracture network for all units and the lithophysal cavities for unit TSw35 (that makes up about $80 \%$ of the repository [CRWMS M\&O 2001d, Section Table 6-1]). Although field evidence points to the fact that very few fractures are active at a given time, the approach presented here assumed that all fractures are susceptible to receive mineralization. 


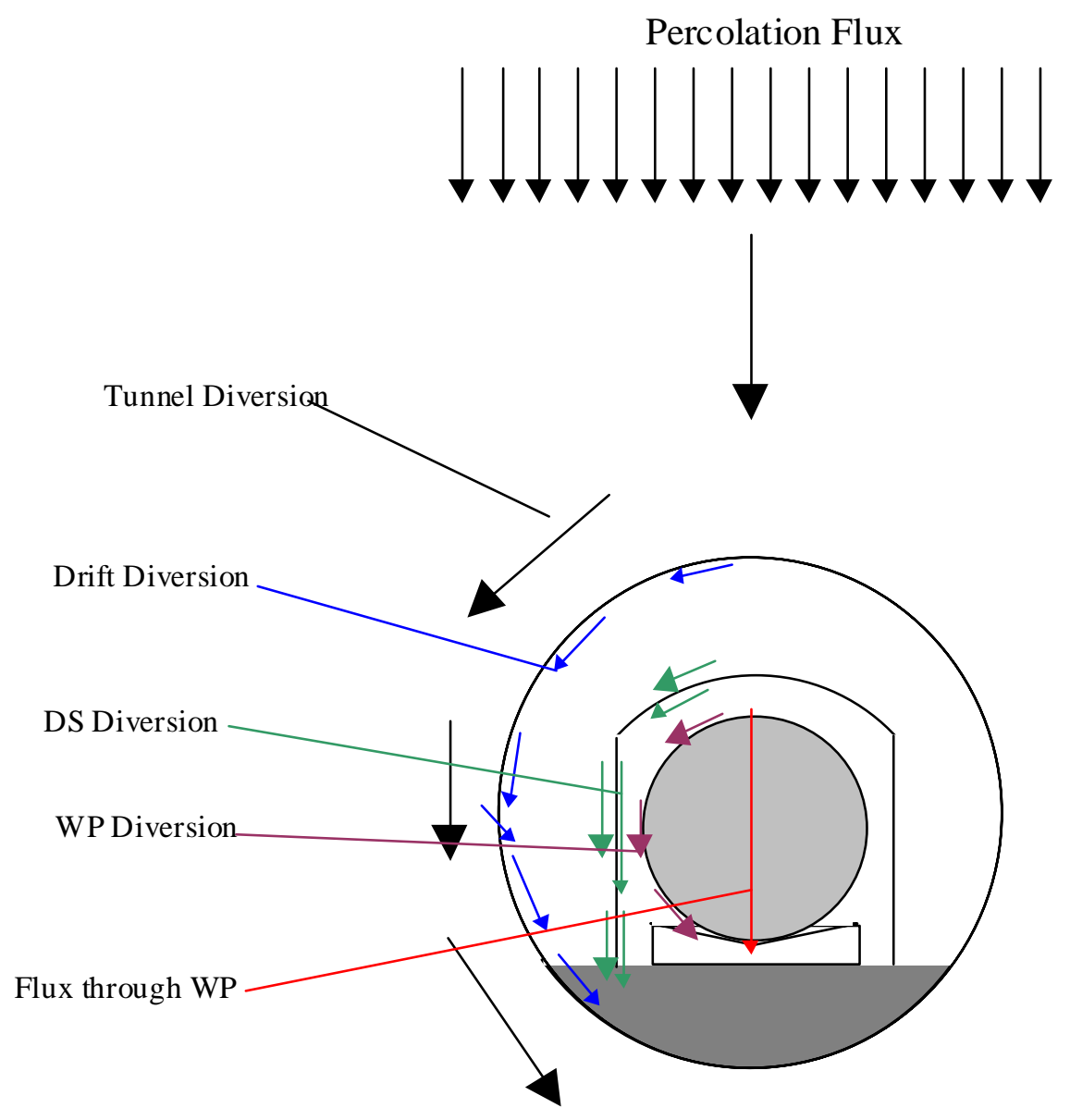

Figure 7-1. Sketch of the Drift Dilution Loci

\subsubsection{Dilution}

The drift seepage AMR (CRWMS M\&O 2000c) provides statistical distributions for the amount of water entering the drift and potentially flowing through the WP for different infiltration conditions. Monte Carlo sampling from the proper combination of all these distributions yields the distribution of the drift seepage. Because of the limited flux of 1.5 or 15 liters per year through the WP, data pertaining to a drift seepage rate between 1 and 20 liter/year were extracted. This range was chosen to encompass the fact that not all the drift seepage may flow through the WP. Table 7-1 (CRWMS M\&O 2001b, Table 5-22) provides a few points of the distribution of dilution factors. Dilution factors are simply the ratio of the flow that would have flowed across the drift footprint, had not the drift been there, to the drift seepage. Inputs from other works suggest that the length of the dilution zone can conservatively be estimated at 10 meters (Assumption 3.2.5). 
Table 7-1. Percentiles of Dilution Factor for the Three Climates (seepage rate between 1 and 20 liter/year)

\begin{tabular}{|l|c|c|c|c|c|c|c|}
\hline Climate & Minimum & $\mathbf{5}^{\text {th }}$ Perc. & $\mathbf{2 5}^{\text {th }}$ Perc. & Median & $\mathbf{7 5}^{\text {th }}$ Perc & $\mathbf{9 5}^{\text {th }}$ Perc. & Maximum \\
\hline Modern & $6.2-6.1$ & $10.8-10.9$ & $22.0-21.6$ & $45.9-44.4$ & $101.1-105.5$ & $374.3-358.3$ & $\begin{array}{c}1518.1- \\
1601.7\end{array}$ \\
\hline Monsoon & $8.4-8.2$ & $16.0-15.5$ & $44.4-46.8$ & $112.2-117.1$ & $239.3-239.2$ & $621.2-634.6$ & $\begin{array}{c}1196.5- \\
1289.9\end{array}$ \\
\hline $\begin{array}{l}\text { Glacial } \\
\text { Transition }\end{array}$ & $8.3-6.8$ & $12.0-12.2$ & $30.1-31.3$ & $74.6-73.6$ & $194.0-198.6$ & $851.2-823.9$ & $\begin{array}{c}1513.1- \\
1339.1\end{array}$ \\
\hline
\end{tabular}

Source: CRWMS M\&O 2001b, Table 5-22

The fracture saturation of the dilution zone is below $10 \%$ most of the time but could reach higher levels in some extremes cases (CRWMS M\&O 2001b, Section 5.3.6.3).

\subsubsection{Fracture Intensity}

The number of fractures intersected along a line is called the fracture frequency. However, the fracture frequency needs to be translated into a volume available for deposition. This volume is the fracture intensity $\left(\mathrm{m}^{2} / \mathrm{m}^{3}\right)$ times the fracture aperture. The average fracture aperture has been estimated at 740 microns in the TSw34 unit (CRWMS M\&O 2001d, Table 6-11). Standard deviations for each unit are also provided in Table 6-13 of CRWMS M\&O (2001d). The fracture intensity is derived from the fracture frequency as given by the Exploratory Studies Facility and Enhanced Characterization of the Repository Block line surveys, as listed in Section 8 of CRWMS M\&O 2001d, by taking into account small fractures, fractures dips, and the correction for bias that results from the line surveys not being orthogonal to all the fractures. Distributions of fracture intensity were built from the field results and then extrapolated to higher fracture intensity potentially conducive to criticality.

A synthetic fracture network is built from the fracture intensity by assuming that smaller fractures are aligned to create longer fractures. All the fractures are assumed to have the same aperture (Assumption 3.2.3). Aperture variations would favor flow in some fractures leading to a less compact mineralization.

\subsubsection{Lithophysae}

Lithophysae vary in size and volume fraction within the TSw35 unit. The average size is about 18 $\mathrm{cm}$ in diameter but can reach over one meter in diameter. There are about 170 observed lithophysal cavities with their largest dimension over 1 meter within the 885 meters of exposure of the TSw35 unit in the Enhanced Characterization of the Repository Block. The lithophysae volume fraction reaches an observed maximum of $27 \%$, but the average is $8.5 \%$ and the mode $5 \%$ (CRWMS M\&O 2001d, Section 6.4). The lithophysae are treated by two different approaches: the equivalent fracture intensity approach and the stand-alone approach. Field studies have shown that most lithophysal cavities are free from any typical secondary minerals (calcite and opal) that would have been brought by water. Actinide precipitation, although different from calcite precipitation, can gain knowledge from it because both are dependent on the behavior of the carbonate system (actinides are transported as carbonate complexes). The following observations on secondary mineral deposition have been made: 
- Secondary minerals occur only on footwalls of fractures (unless steeply dipping) or bottom of lithophysal cavities (Paces et al. 1996, Section 2.1).

- There is no evidence of high-water marks that would indicate localized pooling in lithophysal cavities (Paces et al. 1996, Section 2.1).

- No fracture or cavity is totally filled with secondary minerals (Paces et al. 1996, Section 2.1).

- There is no evidence of dripstone. This suggests that water flows along cavity walls (Marshall et al. 2000).

- Small aperture fracture sections $(<1 \mathrm{~mm})$ typically do not have secondary minerals. Only sections with larger aperture (especially $>5 \mathrm{~mm}$ ) and lithophysal cavities (Paces et al. 1996, Section 2.1).

- Secondary minerals consist mainly of calcite. Opal when present is 1 to $10 \%$ (Paces et al. 1996, Section 2.2).

- Secondary minerals have formed in an unsaturated environment (CRWMS M\&O 20001, Section 6.10.3.4).

- Two characteristics seem needed for abundant calcite precipitation (Paces et al. 1996, Section 2.5 and CRWMS M\&O 20001, Section 6.10.3.4):

- Open space, which is related to easy gas circulation that would enhance liquid-gas exchanges (because accumulation occurs only in lithophysae and large fractures) in particular loss of $\mathrm{CO}_{2}$ and $\mathrm{H}_{2} \mathrm{O}$

- Decreasing velocity of the water film/rivulet that allows more time for exchange (because accumulation occurs on footwalls and cavity bottoms).

These observations encompass the 10 millions years or so since the volcanic pile was emplaced. They cover both the current and wetter climates.

In the equivalent fracture intensity approach, lithophysae are assumed to be only local enlargements in the fracture network. Their main impact is to add additional surface area for deposition. This additional surface area is computed by assuming that all lithophysae are boxshaped with an aspect ratio of 2, that they are intersected by only one fracture and that their maximum dimension is no larger than the fracture spacing. This approach assumes that the mineralization is uniformly distributed over all the available surface areas when precipitation is possible. 
In the stand-alone representation, the accumulation takes place only at the bottom of the cavity and not on the entire available surface. In this approach, it is conservatively assumed that mixing is instantaneous and chemical reactions are fast. The maximum accumulation in a lithophysae is then directly linked to the amount of dilution that can take place. This amount of dilution is a function of both the number of fractures intersected by the cavity and of the flux through each individual fracture. It is assumed that each fracture carries about the same amount of water (Assumption 3.2.7). The accumulation is then at the bottom of the lithophysae but in such a way that it does not hinder outflow.

\subsubsection{Accumulation in the Far-Field: Results}

The accumulation analysis was conducted at specific times out of the entire source term sequence. Two factors guide the choice of these selected times: the actinide aqueous concentration and the $\mathrm{pH}$. When the actinide concentration and the $\mathrm{pH}$ is low $\left(\sim 10-^{4}\right.$ molal and $\sim 7$, respectively), no accumulation is observed along the 100 spatial cells represented by PHREEQC. On the other hand, when actinide concentration and $\mathrm{pH}$ is high $\left(\sim 10-^{2}\right.$ and $\sim 9$, respectively), high accumulations can be expected. The range of selected times encompass the time interval at which actinide precipitation is possible. When the accumulation is potentially high, a finer time discretization is used to avoid unrealistic total accumulations. Because of the discrete sets of times, the final accumulation is sometimes spiky. Use of more time steps would produce individually smaller and smaller peaks and, in the limit, represent the reality of a continuously varying source term yielding a smoother curve. Even in the case of similar total accumulation, there are variations in the density of the accumulation because some source terms (e.g., P52\{rs\}L241 [s4]) (note: source term ID for accumulation study, then ID of the same source term for degradation study) needed more dilution than others to drop the actinides. A higher dilution translates into a larger rock volume to hold the additional water hence a lower density of the mineralization.

Only two of the four source terms analyzed, P52\{rs $\}$ L241 (s4) and P52rLx41 (s5) with two Pu canisters per WP, lead to significant accumulations (CRWMS M\&O 2001b, Section 6). Figure 7-2 (CRWMS M\&O 2001b, Figure 6-24) displays the total non-scaled accumulation by cell from Source Term P52rLx41 (s5) at time 21k years after the time of breach with Pu decay. The overall accumulation is 727.0 moles of uranium and 180.0 moles of plutonium. The plutonium typically precipitates earlier than uranium as $\mathrm{PuO}_{2}$. This case required a high dilution factor to reach the precipitation level because of a high initial ionic strength and $\mathrm{pH}$. Figure 7-3 (CRWMS M\&O 2001b, Figure 6-26) shows the scaled results for the 10-m vertical dilution zone. 


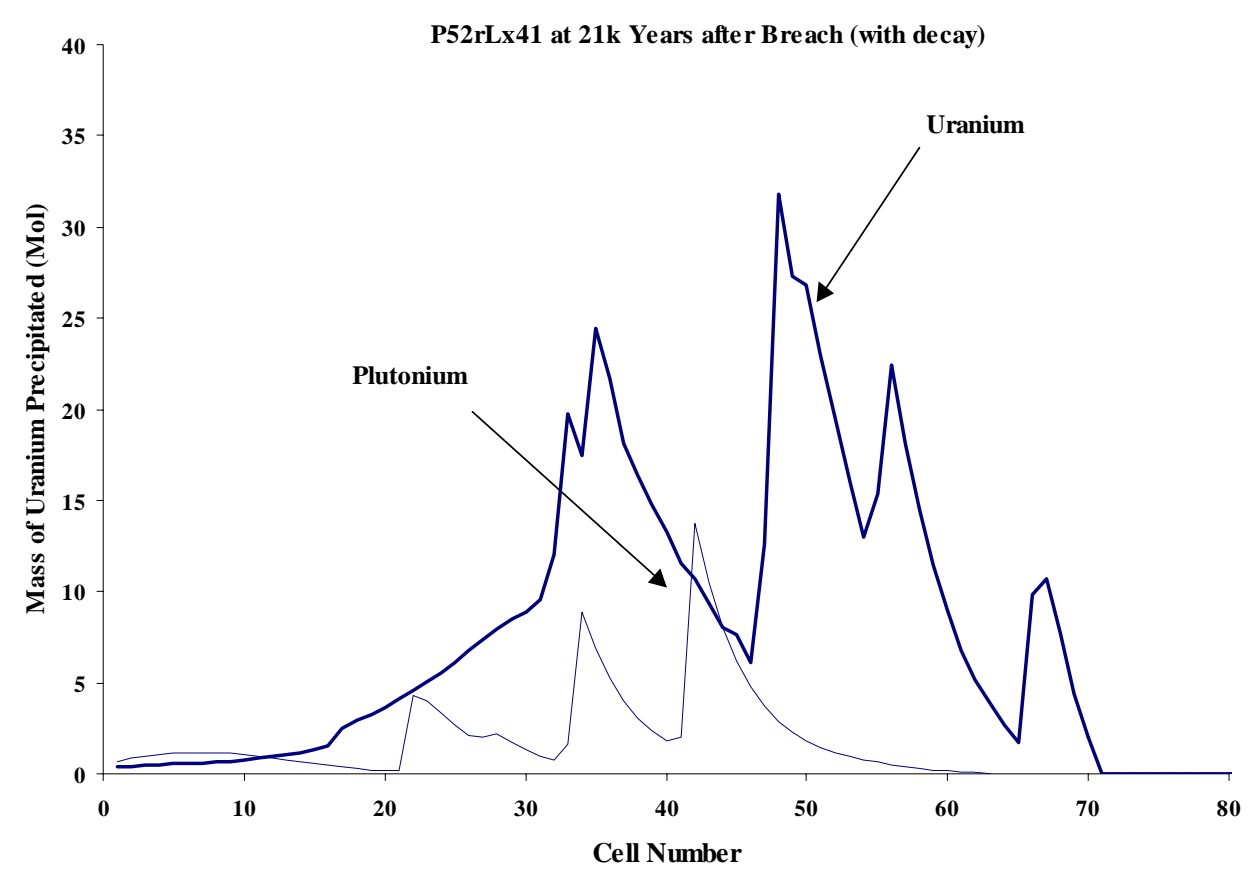

Figure 7-2. Total Accumulation at 21k after Breach Time (P52rLx41); Pu Decay outside of WP

The largest concentration of actinides occurs in a non-lithophysal unit (TSw35) where the fracture intensity can be very high. Values reach 3.75 and $4.67 \mathrm{moles} / \mathrm{m}^{3}$ for uranium and plutonium, respectively, for a fracture water saturation of $10 \%$.

The scaled accumulation density for Source Term P52\{rs\}L241 (s4) is shown in Figure 7-4 (CRWMS M\&O 2001b, Figure 6-16). As shown in Table 7-2, at time 14k years after WP breach, 859.1 moles of uranium have precipitated along with 113.7 moles of plutonium. When Pu decay is taken into account, the maximum Pu mass is reduced to 96.3 moles. The largest concentration of actinides occurs in a non-lithophysal unit (TSw35) where the fracture intensity can be very high. Values reach 3.49 and 3.19 moles $/ \mathrm{m}^{3}$ for uranium and plutonium respectively for a fracture water saturation of $10 \%$.

Results from the four source term cases are summarized in Table 7-2 (CRWMS M\&O 2001b, Table 6-4). 


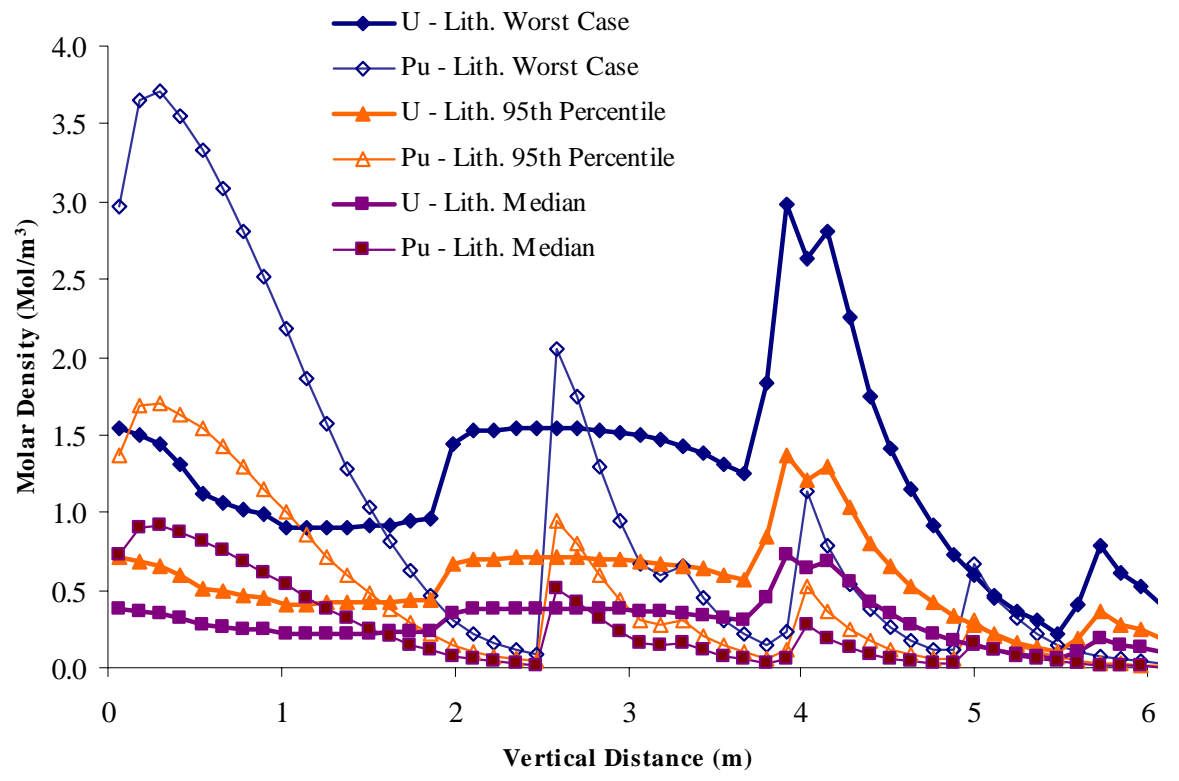

Figure 7-3. P52rLx41 Scaled Accumulation with Lithophysae (no decay)

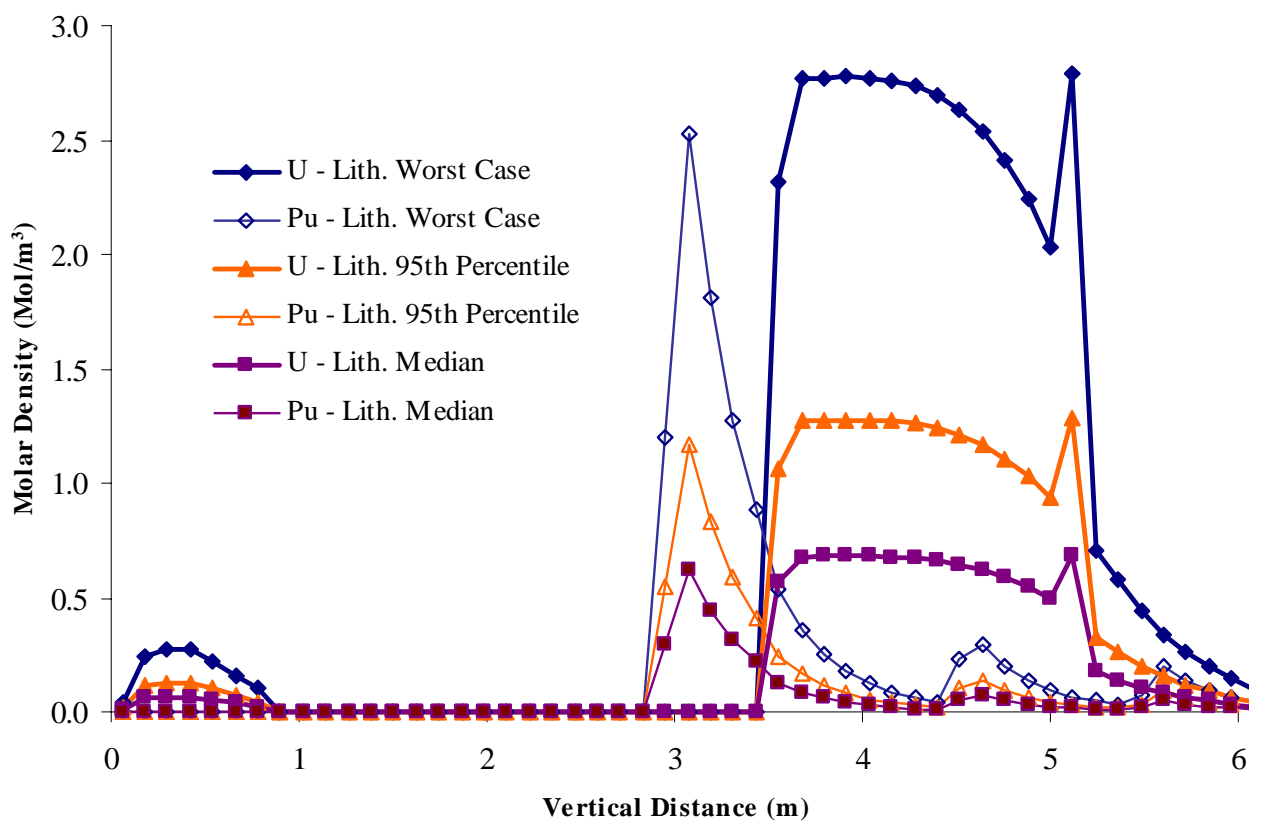

Figure 7-4. P52\{rs\}L241 Scaled Accumulation with Lithophysae (no decay) 
Table 7-2. Summary of Results with a Constant Length Dilution Zone

\begin{tabular}{|c|c|c|c|c|c|c|c|c|c|}
\hline \multirow{3}{*}{$\begin{array}{l}\text { Source Term } \\
\text { (time frame) }\end{array}$} & \multicolumn{2}{|c|}{$\begin{array}{l}\text { Mass through } \\
\text { System }\end{array}$} & \multicolumn{2}{|c|}{$\begin{array}{c}\text { Accumulation } \\
\text { No decay }\end{array}$} & \multicolumn{3}{|c|}{ Accumulation with Decay } & \multicolumn{2}{|c|}{$\begin{array}{c}\text { Highest Density } \\
\text { (with Cell Number) } \\
\text { at Saturation of } 10 \%\end{array}$} \\
\hline & \multirow{2}{*}{$\underset{(\mathrm{mol})}{U}$} & \multirow{2}{*}{$\underset{(\mathrm{mol})}{\mathrm{Pu}}$} & \multirow{2}{*}{$\underset{(\mathrm{mol})}{\mathbf{U}}$} & \multirow{2}{*}{$\underset{(\mathrm{mol})}{\mathrm{Pu}}$} & \multicolumn{2}{|c|}{ U (mol) } & \multirow{2}{*}{$\underset{(\mathrm{mol})}{\mathrm{Pu}}$} & \multirow{2}{*}{$\underset{\left(\mathrm{mol} / \mathrm{m}^{3}\right)}{U}$} & \multirow{2}{*}{$\begin{array}{c}\mathrm{Pu} \\
\left(\mathrm{mol} / \mathrm{m}^{3}\right)\end{array}$} \\
\hline & & & & & $\begin{array}{l}\text { Non- } \\
\text { Fissile }\end{array}$ & Fissile & & & \\
\hline $\begin{array}{c}\text { P51_1131 (s1) } \\
(50 \mathrm{k}-63 \mathrm{k})\end{array}$ & 1000.7 & 14.0 & NC & 10.3 & \multicolumn{2}{|c|}{ NC } & NC & $\begin{array}{c}6.55 \\
(1)-N D\end{array}$ & $\begin{array}{c}4.69 \\
(1)-N D\end{array}$ \\
\hline $\begin{array}{c}\text { P52\{rs\}L241 (s4) } \\
(0.7 \mathrm{k}-14 \mathrm{k})\end{array}$ & 833.6 & 115.9 & 851.9 & 113.7 & 632.0 & 234.8 & 96.3 & $\begin{array}{c}3.49 \\
(32)-\mathrm{ND}\end{array}$ & $\begin{array}{c}3.19 \\
(26)-\mathrm{ND}\end{array}$ \\
\hline $\begin{array}{l}\text { P52rLx41 (s5) } \\
(5 k-23 k))\end{array}$ & 1186.3 & 159.7 & 727.0 & 180.0 & 481.0 & 183.2 & 137.9 & $\begin{array}{c}3.75 \\
(31)-N D\end{array}$ & $\begin{array}{c}4.67 \\
(1)-N D\end{array}$ \\
\hline $\begin{array}{c}\text { P51_1132(s2) } \\
(40 \mathrm{k}-85 \mathrm{k})\end{array}$ & 973.7 & 12.4 & 298.3 & 5.4 & \multicolumn{2}{|c|}{$\mathrm{NC}$} & $\mathrm{NC}$ & $\begin{array}{c}8.60 \\
(1)-N D\end{array}$ & $\begin{array}{c}0.45 \\
(1)-N D\end{array}$ \\
\hline
\end{tabular}

NOTES: ${ }^{a}$ Source term identification with degradation calculation

${ }^{b}$ for "worst case" with fracture porosity $=6.5 \%$ and high dilution NC: Not computed; ND: No decay

In the stand-alone lithophysae representation, the mixing is assumed to occur instantaneously at the bottom of the lithophysal cavity. Depending on the source term, as little as one volume of resident water mixing with one volume of WP water is sufficient to precipitate $\mathrm{Pu}$. In some other cases, the volume ratio has to approach 50, but the probability of this situation is small. As in the equivalent fracture intensity approach, the final accumulation is the weighted sum of the results from each selected time.

Figures 7-5 and 7-6 (CRWMS M\&O 2001b, Figures 6-28 and 6-29) show the effect of dilution on the level of actinide precipitation at two time points when one liter of effluent water is instantaneously mixed with a given volume of resident water. The resident water volume is varied up to 1000 liter. These cases represent the behavior of actinide precipitation in a lithophysal cavity where the mixing of waters flowing from different fractures is assumed to be instantaneous. A summary of the accumulation results in a 1-m lithophysal cavity with a high fracture intensity corresponding to a dilution ratio of 85 is given in Table 7-3 (CRWMS M\&O 2001b, Table 6-5). Significant accumulation was observed only from source terms from WPs containing two $\mathrm{Pu}$ ceramic canisters. 


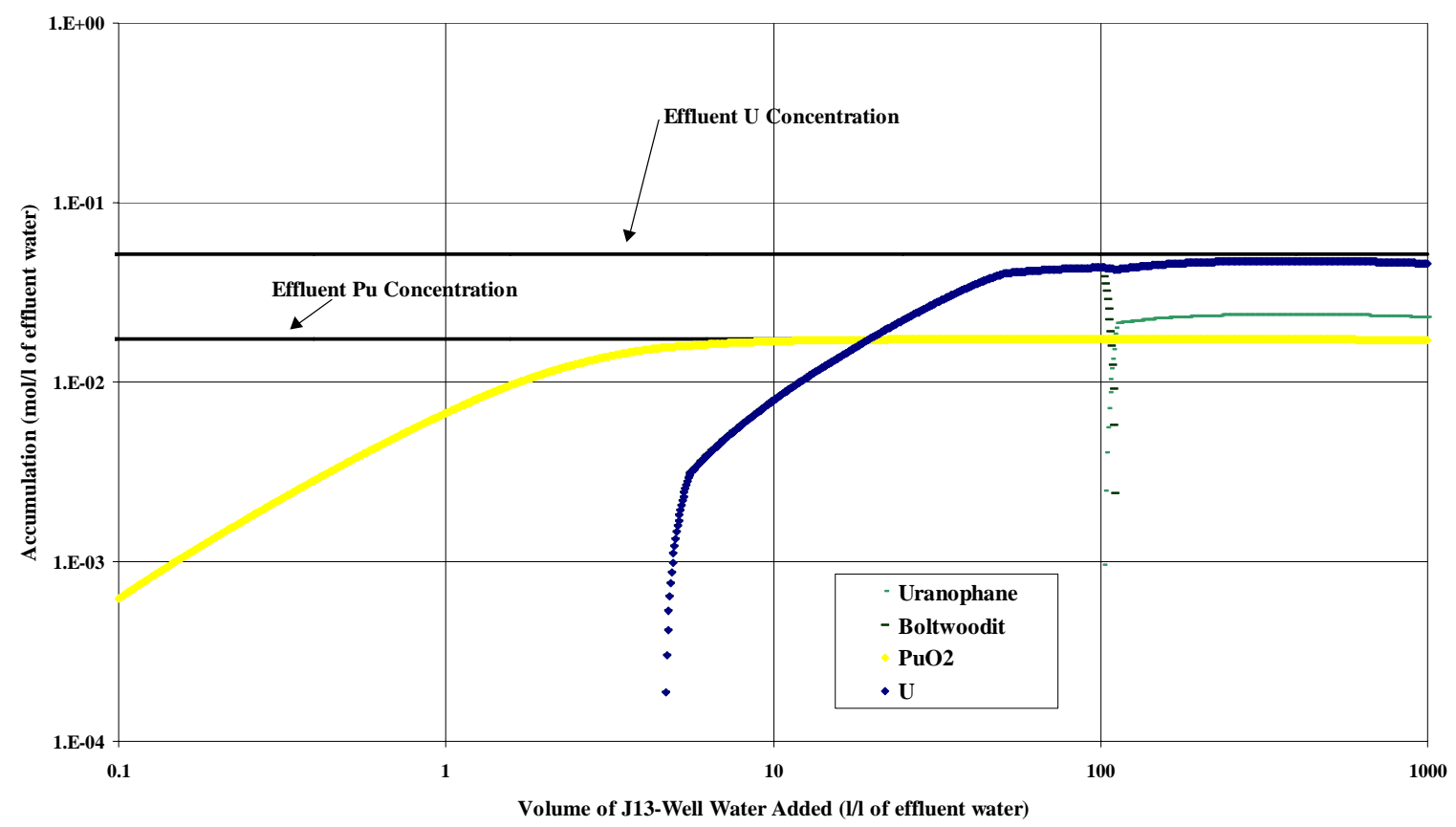

Figure 7-5. Actinide Precipitation as a Function of Dilution (P52rLx41 source term at 7.4k)

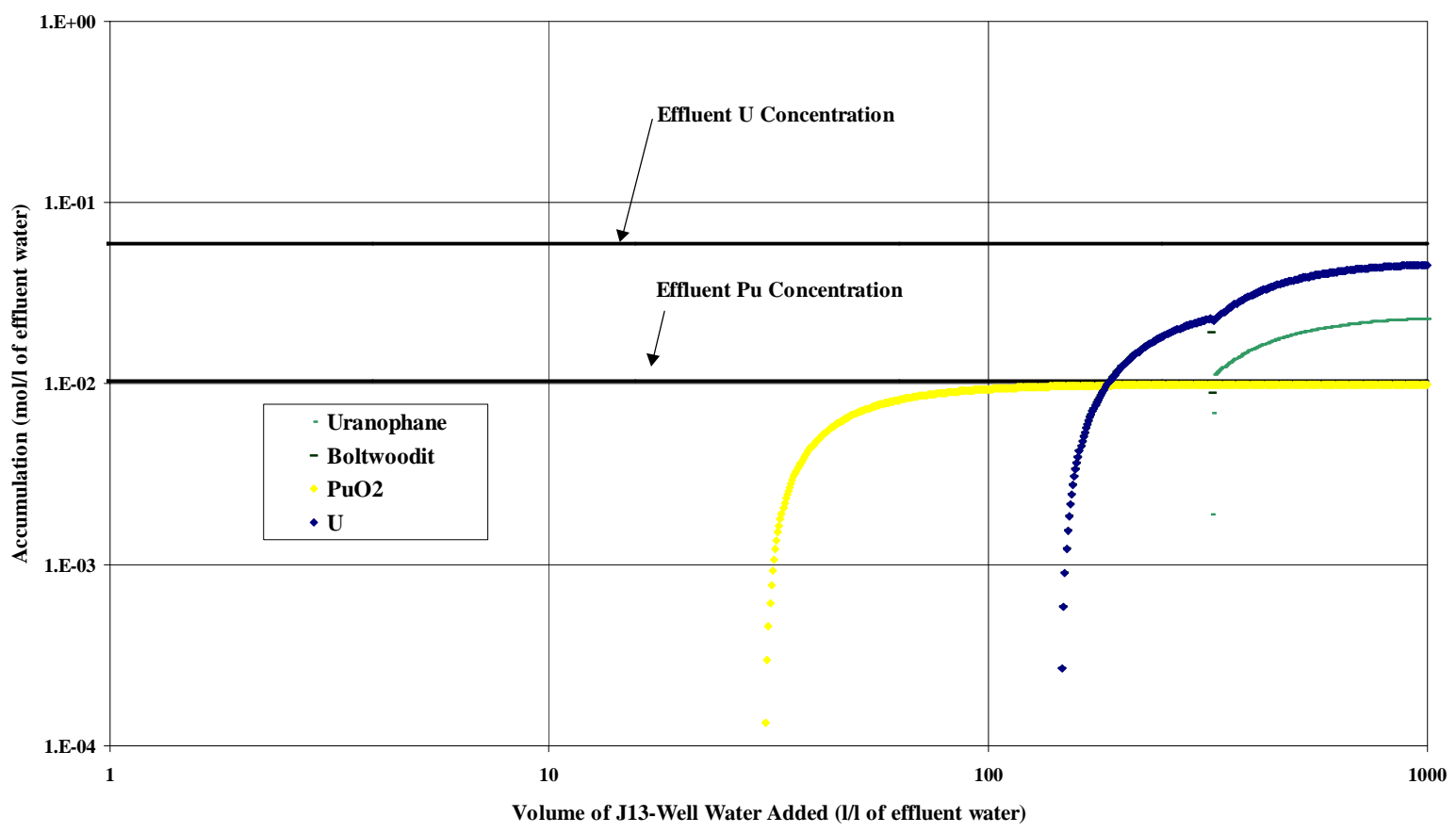

Figure 7-6. Actinide Precipitation as a Function of Dilution (P52rLx41 source term at 10k) 
Table 7-3. Summary of Accumulation in One Meter Diameter Lithophysal Cavity with High Fracture Intensity

\begin{tabular}{|c|c|c|c|}
\hline \multirow[b]{2}{*}{$\begin{array}{c}\text { Source Term } \\
\text { (time frame) }\end{array}$} & \multicolumn{2}{|c|}{ Total U (mole) } & \multirow[b]{2}{*}{ Total Pu (mole) } \\
\hline & $\begin{array}{l}\text { Non- } \\
\text { Fissile }\end{array}$ & Fissile & \\
\hline $\begin{array}{c}\text { P51_1131 (s1) } \\
(50 \mathrm{k}-63 \mathrm{k})\end{array}$ & \multicolumn{2}{|c|}{$\mathrm{NC}$} & 10.29 - ND \\
\hline $\begin{array}{c}\text { P52 }\{r s\} L 241(s 4) \\
(0.7 k-14 k) \\
\end{array}$ & 352.8 & 132.5 & $64.9-\mathrm{DC}$ \\
\hline $\begin{array}{c}\text { P52rLx41 (s5) } \\
(5 \mathrm{k}-23 \mathrm{k}))\end{array}$ & 214.5 & 86.4 & $93.0-\mathrm{DC}$ \\
\hline $\begin{array}{c}\mathrm{P} 51 \ldots 1132(\mathrm{~s} 2) \\
(40 \mathrm{k}-85 \mathrm{k})\end{array}$ & \multicolumn{2}{|c|}{$\mathrm{NC}$} & $5.21-N D$ \\
\hline
\end{tabular}

NOTES: All results for fracture intensity of $85 \mathrm{~m} / \mathrm{m}^{2}$

NC: Not computed; ND: No decay; DC: Decay

\subsubsection{Sensitivity Studies}

The influence of rock dissolution (through surface area) and the details of the representation of dilution (mixing ratio) have been investigated and found of little importance. Another resident water, different from the J-13 well water and known as pore water, has also been investigated. Those two waters represent reasonable bounds on the resident water. Total $\mathrm{Pu}$ accumulations with pore water are slightly larger (by 13\%) in the case of P52\{rs\}L241 (s4).

Other sensitivity analysis, higher $\mathrm{CO}_{2}$ partial pressure and inhibition of Na-boltwoodite and $\mathrm{PuO}_{2}$ for minerals observed in experiments (schoepite and $\mathrm{Pu}(\mathrm{OH})_{4}$ ) yield very little accumulation. 


\section{CRITICALITY EVALUATIONS}

The criticality evaluations for the accumulations in the far-field (host rock beneath the waste package) of fissile material external to waste packages containing plutonium disposition ceramic waste form (CRWMS M\&O 2001c) are summarized in this section. Figure 8-1 (CRWMS M\&O 2001c, Figure 5-1) shows the waste package and an idealized representation of lithophysae and fractures in the tuff immediately beneath. The geochemistry degradation studies (Section 6) identified four source terms resulting in significant Pu accumulations. The nominal source terms (P51_1131 [s1] and P51_1132 [s2]) are based on the current plan to place one plutonium-bearing canister per waste package. The nominal source terms represent a low and high seepage rate, respectively (Table 6-1). A misload source term (P52\{rs\}L241 [s4]) that is based on placing two plutonium-bearing canisters in a waste package. The degradation rates for the misload case are optimized such that the source term would have a pH level favorable for accumulation and at the same time high enough to allow for significant solubility of fissile material, which resulted in the fourth source term (P52rLx41 [s5]). Accumulations from the latter two source terms were the only ones sufficiently large to pose a criticality threat. Two representations of accumulation in the external environment are considered for criticality evaluations: (1) film accumulation along the walls of fractures and relatively small lithophysae discussed in Section 8.1 and (2) layer accumulation on the bottom of a relatively large lithophysae discussed in Section 8.2. The criticality evaluations of selected cases with the most significant accumulations of fissile material are summarized in Section 8.3. The probability of criticality for the critical configurations is presented in Section 8.4.

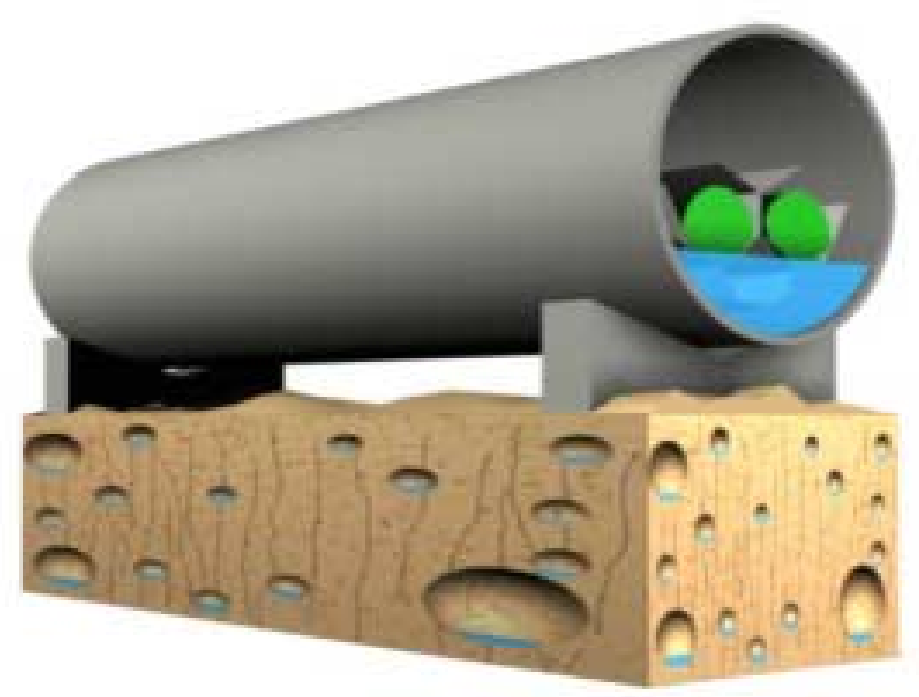

Figure 8-1. Far-Field Representation (not to scale) 


\subsection{Film Accumulation}

Fissile material can accumulate along the walls of fractures and lithophysae. The main condition to allow for accumulation is sufficient mixing between the effluent water and adequate fresh water to neutralize the mixture and lower the $\mathrm{pH}$ levels sufficiently for uranium and plutonium to become insoluble and precipitate. Due to the nature of the flow from the waste package and through the fractures, geochemistry calculations (Section 7) show that the accumulation will spread out as the fissile materials flow deeper into the tuff. This results in a conical accumulation volume. Since the nature of the computer code used for accumulation calculations requires finite volumes, the accumulation volume is represented with layers as shown in Figure 8-2 (CRWMS M\&O 2001c, Figure 5-2). The number of layers, their depth, and their radii vary based on the PHREEQC accumulation representation (CRWMS M\&O 2001b). The fissile material accumulated in every layer is homogenized throughout that layer for the criticality calculations since the actual fracture structure is impossible to represent. Table 8-1 (CRWMS M\&O 2001c, Table 5-2) gives a summary of the accumulation calculations in fractures only for non-lithophysal zones that resulted in significant fissile material accumulation. The significant accumulations of fissile materials in the lithophysal zone are summarized in Table 6-2 from CRWMS M\&O 2001b. The equivalent fracture representation treats the lithophysae as if they were wide fractures where accumulation occurs only along the walls of the lithophysae with film flow of effluent and fresh water. In the cases where large lithophysae are considered, the surface area of the lithophysae does not compensate for the reduction of fractures due to the void volume occupied by the lithophysae. In other words, the smaller the lithophysae, the more conservative the calculation. The accumulation results for such calculations are shown in Table 8-2 (CRWMS M\&O 2001c, Table 5-3). Definitions of terms abbreviated in the column headings for these two tables are: "Inf." - Infiltration, "Fract." - Fracture, "Int." - Intensity, "Sat." - Saturation, "Por." Porosity, "Lith." - Lithophysae, and "Acc." - Accumulation.

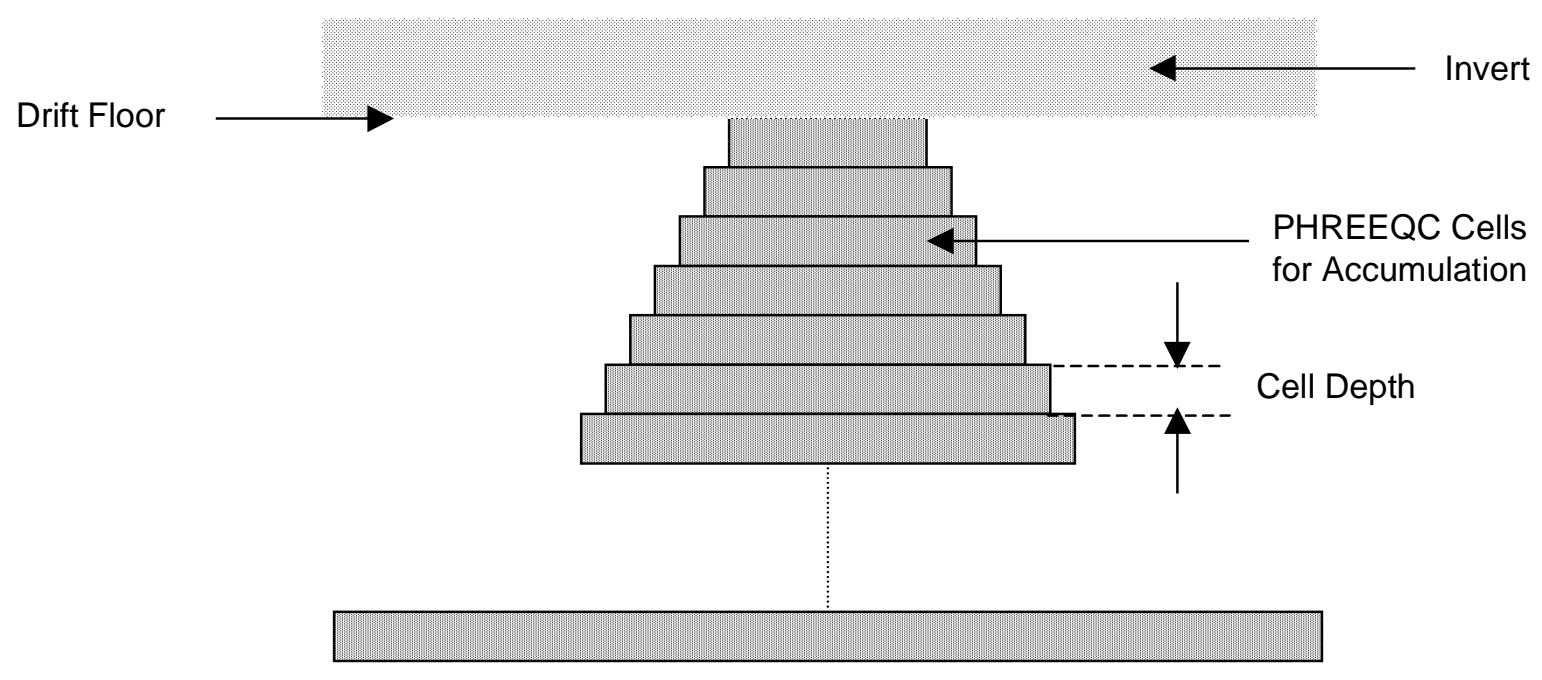

Figure 8-2. Far-Field Representation (not to scale) 
Table 8-1. Summary of Accumulation in Fractures Only

\begin{tabular}{|c|c|c|c|c|c|c|c|c|c|}
\hline PHREEQC Case & $\begin{array}{l}\text { Time } \\
\text { (years) }\end{array}$ & $\begin{array}{c}\text { Inf. Rate } \\
\text { (I/year) }\end{array}$ & Sat. & $\begin{array}{l}\text { Fracture } \\
\text { Porosity }\end{array}$ & $\begin{array}{l}\text { Cell Depth } \\
\text { (m) }\end{array}$ & $\begin{array}{l}\text { Top Acc. Cell } \\
\text { Radius (m) }\end{array}$ & $\begin{array}{l}{ }^{239} \mathrm{Pu} \\
\text { (mole) }\end{array}$ & $\underset{\text { (mole) }}{\mathbf{U}}$ & $\begin{array}{l}\text { Average }{ }^{235} \mathrm{U} \\
\text { Enrichment in Top } \\
10 \text { Cells }\end{array}$ \\
\hline P52rLx41 (s5) & 21,000 & 10,000 & 1 & 0.065 & 0.12 & 0.26 & 137.89 & 664.2 & 0.5744 \\
\hline P52rLx41 (s5) & 21,000 & 10,000 & 0.5 & 0.065 & 0.12 & 0.37 & 137.89 & 664.2 & 0.5744 \\
\hline P52\{rs\}L241 (s4) & 14,000 & 10,000 & 1 & 0.065 & 0.12 & 0.92 & 96.3 & 866.8 & 0.6319 \\
\hline P52\{rs\}L241 (s4) & 14,000 & 10,000 & 0.5 & 0.065 & 0.12 & 1.30 & 96.3 & 866.8 & 0.6319 \\
\hline
\end{tabular}

Table 8-2. Summary of Accumulation in Fracture and Lithophysae Equivalent Fractures

\begin{tabular}{|c|c|c|c|c|c|c|c|c|c|c|c|}
\hline $\begin{array}{c}\text { PHREEQC } \\
\text { Case }\end{array}$ & $\begin{array}{c}\text { Time } \\
\text { (years) }\end{array}$ & $\begin{array}{c}\text { Inf. Rate } \\
\text { (I/year) }\end{array}$ & Sat. & $\begin{array}{l}\text { Fract. } \\
\text { Int. }\end{array}$ & $\begin{array}{l}\text { Fract. } \\
\text { Por. }\end{array}$ & $\begin{array}{l}\text { Lith. } \\
\text { Por. }\end{array}$ & $\begin{array}{c}\text { Cell } \\
\text { Depth } \\
(\mathbf{m})\end{array}$ & $\begin{array}{l}\text { Top Acc. } \\
\text { Cell Radius } \\
\text { (m) }\end{array}$ & $\begin{array}{l}{ }^{239} \mathrm{Pu} \\
\text { (mole) }\end{array}$ & $\begin{array}{c}\text { U } \\
\text { (mole) }\end{array}$ & $\begin{array}{l}\text { Average }{ }^{235} \mathrm{U} \\
\text { Enrichment in } \\
\text { Top } 10 \text { Cells }\end{array}$ \\
\hline P52rLx41 (s5) & 21,000 & 10,000 & 1 & 25 & 0.027 & 0.27 & 0.12 & 0.29 & 137.9 & 910.0 & 0.5114 \\
\hline P52rLx41 (s5) & 21,000 & 10,000 & 1 & 20 & 0.022 & 0.27 & 0.12 & 0.29 & 137.9 & 910.0 & 0.5114 \\
\hline P52rLx41 (s5) & 21,000 & 10,000 & 1 & 18 & 0.02 & 0.27 & 0.12 & 0.29 & 137.9 & 910.0 & 0.5114 \\
\hline P52rLx41 (s5) & 21,000 & 1,000 & 1 & 18 & 0.02 & 0.27 & 0.164 & 0.25 & 137.9 & 850.3 & 0.5114 \\
\hline P52rLx41 (s5) & 21,000 & 500 & 1 & 18 & 0.02 & 0.27 & 0.182 & 0.24 & 136.1 & 746.2 & 0.5114 \\
\hline P52rLx41 (s5) & 21,000 & 100 & 1 & 18 & 0.02 & 0.27 & 0.256 & 0.20 & 73.3 & 379.3 & 0.5114 \\
\hline P52rLx41 (s5) & 21,000 & 50 & 1 & 18 & 0.02 & 0.27 & 0.303 & 0.18 & 42.9 & 187.3 & 0.5114 \\
\hline P52rLx41 (s5) & 21,000 & 10,000 & 1 & 12 & 0.011 & 0.18 & 0.12 & 0.43 & 137.9 & 910.0 & 0.5114 \\
\hline P52rLx41 (s5) & 21,000 & 1,000 & 1 & 12 & 0.011 & 0.18 & 0.164 & 0.42 & 137.9 & 850.3 & 0.5114 \\
\hline P52rLx41 (s5) & 21,000 & 100 & 1 & 12 & 0.011 & 0.18 & 0.182 & 0.29 & 73.3 & 379.3 & 0.5114 \\
\hline P52rLx41 (s5) & 21,000 & 10,000 & 0.5 & 18 & 0.02 & 0.27 & 0.12 & 0.41 & 137.9 & 910.0 & 0.5114 \\
\hline P52rLx41 (s5) & 21,000 & 10,000 & 0.5 & 12 & 0.011 & 0.18 & 0.12 & 0.61 & 137.9 & 910.0 & 0.5114 \\
\hline P52\{rs\}L241 (s4) & 14,000 & 10,000 & 1 & 18 & 0.02 & 0.27 & 0.12 & 1.034 & 96.3 & 866.8 & 0.6319 \\
\hline P52\{rs\}L241 (s4) & 14,000 & 1,000 & 1 & 18 & 0.02 & 0.27 & 0.164 & 0.89 & 95.7 & 840.4 & 0.6319 \\
\hline P52\{rs\}L241 (s4) & 14,000 & 500 & 1 & 18 & 0.02 & 0.27 & 0.182 & 0.84 & 92.9 & 723.5 & 0.6319 \\
\hline P52\{rs\}L241 (s4) & 14,000 & 100 & 1 & 18 & 0.02 & 0.27 & 0.256 & 0.71 & 53.7 & 310.8 & 0.6319 \\
\hline P52\{rs\}L241 (s4) & 14,000 & 50 & 1 & 18 & 0.02 & 0.27 & 0.303 & 0.65 & 43.5 & 89.6 & 0.6319 \\
\hline P52\{rs\}L241 (s4) & 14,000 & 10,000 & 1 & 12 & 0.011 & 0.18 & 0.12 & 1.52 & 96.3 & 866.8 & 0.6319 \\
\hline P52\{rs\}L241 (s4) & 14,000 & 1,000 & 1 & 12 & 0.011 & 0.18 & 0.164 & 1.31 & 95.7 & 840.4 & 0.6319 \\
\hline P52\{rs\}L241 (s4) & 14,000 & 100 & 1 & 12 & 0.011 & 0.18 & 0.182 & 1.05 & 53.7 & 310.8 & 0.6319 \\
\hline P52\{rs\}L241 (s4) & 14,000 & 10,000 & 0.5 & 18 & 0.02 & 0.27 & 0.12 & 1.46 & 96.3 & 866.8 & 0.6319 \\
\hline P52\{rs\}L241 (s4) & 14,000 & 10,000 & 0.5 & 12 & 0.011 & 0.18 & 0.12 & 2.16 & 96.3 & 866.8 & 0.6319 \\
\hline
\end{tabular}




\subsection{Layer Accumulation}

Layer accumulation can only occur at the bottom of lithophysae. The spherical representation of lithophysae discussed in CRWMS M\&O (2001b) requires some ponding and enough dilution in a single lithophysae such that fissile materials can accumulate at the bottom of a single and relatively large lithophysae. Table 8-3 lists a summary of the geochemistry calculations for the spherical representation of lithophysae (CRWMS M\&O 2001c, Table 5-4).

Table 8-3. Summary of Accumulation in Large Spherical Lithophysae

\begin{tabular}{|c|c|c|c|c|c|c|c|}
\hline $\begin{array}{l}\text { PHREEQC } \\
\text { Case Name }\end{array}$ & $\begin{array}{c}\text { Time } \\
\text { (years) }\end{array}$ & $\begin{array}{l}\text { Lithophysae } \\
\text { Diameter } \\
\text { (m) }\end{array}$ & $\begin{array}{c}\text { Percentage of } \\
\text { Lithophysae } \\
\text { Filled }\end{array}$ & $\begin{array}{l}\text { Number of } \\
\text { Fractures per } \\
\text { Lithophysae }\end{array}$ & $\begin{array}{l}{ }^{239} \mathrm{Pu} \\
\text { (mole) }\end{array}$ & U (mole) & $\begin{array}{c}{ }^{235} \mathrm{U} \\
\text { Enrichment } \\
\text { (atom \%) }\end{array}$ \\
\hline P52rLx41 (s5) & 21,000 & 1 & 0.9 & 12 & 38.8 & 36.7 & 0.262 \\
\hline P52rLx41 (s5) & 21,000 & 1 & 1.6 & 24 & 51.0 & 73.3 & 0.241 \\
\hline P52rLx41 (s5) & 21,000 & 1 & 2.3 & 36 & 61.2 & 110.0 & 0.268 \\
\hline P52rLx41 (s5) & 21,000 & 1 & 3.4 & 48 & 76.9 & 162.9 & 0.266 \\
\hline P52rLx41 (s5) & 21,000 & 1 & 3.9 & 61 & 83.6 & 191.9 & 0.263 \\
\hline P52rLx41 (s5) & 21,000 & 1 & 4.2 & 73 & 86.6 & 204.6 & 0.263 \\
\hline P52rLx41 (s5) & 21,000 & 1 & 6.0 & 85 & 93.0 & 300.9 & 0.287 \\
\hline P52rLx41 (s5) & 21,000 & 0.5 & 3.2 & 6 & 22.2 & 16.3 & 0.233 \\
\hline P52rLx41 (s5) & 21,000 & 0.5 & 6.8 & 12 & 38.8 & 36.7 & 0.262 \\
\hline P52rLx41 (s5) & 21,000 & 0.5 & 9.9 & 18 & 48.0 & 54.7 & 0.250 \\
\hline P52rLx41 (s5) & 21,000 & 0.5 & 12.7 & 24 & 51.0 & 73.3 & 0.241 \\
\hline P52rLx41 (s5) & 21,000 & 0.5 & 15.3 & 30 & 52.2 & 90.2 & 0.235 \\
\hline P52rLx41 (s5) & 21,000 & 0.5 & 18.5 & 36 & 61.2 & 110 & 0.268 \\
\hline P52rLx41 (s5) & 21,000 & 0.5 & 23.2 & 42 & 70.7 & 138.9 & 0.269 \\
\hline P52rLx41 (s5) & 21,000 & 0.25 & 13.2 & 3 & 18.9 & 6.5 & 0.263 \\
\hline P52rLx41 (s5) & 21,000 & 0.25 & 25.8 & 6 & 22.2 & 16.3 & 0.234 \\
\hline P52rLx41 (s5) & 21,000 & 0.25 & 39.5 & 9 & 26.7 & 26.8 & 0.259 \\
\hline P52rLx41 (s5) & 21,000 & 0.25 & 54.8 & 12 & 38.8 & 36.7 & 0.262 \\
\hline P52rLx41 (s5) & 21,000 & 0.25 & 67.2 & 15 & 44.7 & 45.7 & 0.256 \\
\hline P52rLx41 (s5) & 21,000 & 0.25 & 78.9 & 18 & 48.0 & 54.7 & 0.250 \\
\hline
\end{tabular}

\subsection{Criticality Evaluations}

For the cases representing film accumulation along the fracture and lithophysae wall, the fissile material accumulated in every layer is homogenized with tuff throughout that layer for the criticality calculations. The composition of the tuff rock is given in Table 8-4 (Lipman et al. 1966). The porosity of the tuff below the repository is $17.2 \%$, which is assumed to be fully saturated. The fractures and lithophysae are also assumed to be fully saturated. 
Table 8-4. Tuff Composition

\begin{tabular}{|c|c|}
\hline Mineral & Weight Percent \\
\hline $\mathrm{SiO}_{2}$ & 76.83 \\
\hline $\mathrm{Al}_{2} \mathrm{O}_{3}$ & 12.74 \\
\hline $\mathrm{FeO}$ & 0.84 \\
\hline $\mathrm{MgO}$ & 0.25 \\
\hline $\mathrm{CaO}$ & 0.56 \\
\hline $\mathrm{Na}_{2} \mathrm{O}$ & 3.59 \\
\hline $\mathrm{K}_{2} \mathrm{O}$ & 4.93 \\
\hline $\mathrm{TiO}_{2}$ & 0.1 \\
\hline $\mathrm{P}_{2} \mathrm{O}_{5}$ & 0.02 \\
\hline $\mathrm{MnO}$ & 0.07 \\
\hline $\mathrm{Particle} \mathrm{Density}=2.54 \mathrm{~g} / \mathrm{cm}^{3}$ \\
$($ DTN: MO9708RIB00040.000) \\
\hline
\end{tabular}

k-effective evaluations of the accumulation calculation in non-lithophysal zone taking into account fractures only with 6.5\% porosity are listed in Table 8-5 (CRWMS M\&O 2001c, Table 6-1).

Table 8-5. $\mathrm{k}_{\mathrm{eff}}$ Values for Accumulation in Fractures Only

\begin{tabular}{|l|c|c|c|c|c|}
\hline $\begin{array}{c}\text { PHREEQC } \\
\text { Case Name }\end{array}$ & $\begin{array}{c}\text { Fracture } \\
\text { Porosity }\end{array}$ & Saturation & $\begin{array}{c}\text { Inf. Rate } \\
\text { (I/year) }\end{array}$ & keff $_{\text {ear }}$ & $\boldsymbol{\sigma}$ \\
\hline P52rLx41 (s5) & 0.065 & 1 & 10,000 & 0.91491 & 0.00081 \\
\hline P52rLx41 (s5) & 0.065 & 0.5 & 10,000 & 0.77015 & 0.00065 \\
\hline P52 $\{r s\} L 241(s 4)$ & 0.065 & 1 & 10,000 & 0.87433 & 0.00054 \\
\hline P52\{rs\}L241 (s4) & 0.065 & 0.5 & 10,000 & 0.60436 & 0.00045 \\
\hline
\end{tabular}

Descriptions and results for the accumulation cases for accumulation in the lithophysal zone taking into account fractures and lithophysae as equivalent fractures are listed in Table 8-6 (CRWMS M\&O 2001c, Table 6-2). Since the accumulation volume is in a conical shape, the volumes of the bottom cells are relatively large, which lowers the density of fissile material, which, in turn, lowers the contribution of those cells to the system reactivity. In most cases, only the top 10 cells have sufficiently high fissile material density to contribute to potential criticalities. Table 8-7 (CRWMS $\mathrm{M} \& \mathrm{O}$ 2001c, Table 6-2) lists the k-effective values for the only critical case in the film accumulation representation for cases when using only the top layers. The change in k-effective is within $1 \sigma$ when going down to 10 layers. The effective critical volume for this case is simply the volume of the top 10 layers, which is found to be $0.413 \mathrm{~m}^{3}$ as taken from Table 6-4 of CRWMS $\mathrm{M} \& \mathrm{O}$ (2001c). This volume has to be intersected by enough fractures to allow for flow, mixing, and accumulation. In order to quantify the probability of having enough fractures intersecting such volume to accumulate the desired fissile material at the desired density, a characteristic length of this volume is determined. The characteristic length is simply defined as the diameter of a sphere with the same volume as the critical conical volume. The probability of having enough fractures intersecting the defined characteristic length is calculated in a Monte Carlo simulation as described in Section 8.4.1.8. 
Table 8-6. $\quad \mathrm{k}_{\text {eff }}$ Values for Accumulation in Fractures and Lithophysae as Equivalent Fractures

\begin{tabular}{|c|c|c|c|c|c|c|c|}
\hline $\begin{array}{c}\text { PHREEQC } \\
\text { Case Name }\end{array}$ & Saturation & $\begin{array}{c}\text { Inf. Rate } \\
\text { (I/year) }\end{array}$ & $\begin{array}{l}\text { Fracture } \\
\text { Porosity }\end{array}$ & $\begin{array}{l}\text { Lithophysae } \\
\text { Porosity }\end{array}$ & $\begin{array}{c}\text { Matrix } \\
\text { Porosity }\end{array}$ & $\mathbf{k}_{\text {eff }}$ & $\sigma$ \\
\hline P52rLx41 (s5) & 1 & 10,000 & 0.027 & 0.27 & 17.2 & 0.99199 & 0.00065 \\
\hline P52rLx41 (s5) & 1 & 10,000 & 0.022 & 0.27 & 17.2 & 0.93920 & 0.00063 \\
\hline P52rLx41 (s5) & 1 & 10,000 & 0.02 & 0.27 & 17.2 & 0.93383 & 0.00066 \\
\hline P52rLx41 (s5) & 1 & 1,000 & 0.02 & 0.27 & 17.2 & 0.90121 & 0.00063 \\
\hline P52rLx41 (s5) & 1 & 500 & 0.02 & 0.27 & 17.2 & 0.88920 & 0.00076 \\
\hline P52rLx41 (s5) & 1 & 100 & 0.02 & 0.27 & 17.2 & 0.84115 & 0.00058 \\
\hline P52rLx41 (s5) & 1 & 50 & 0.02 & 0.27 & 17.2 & 0.84753 & 0.00056 \\
\hline P52rLx41 (s5) & 1 & 10,000 & 0.011 & 0.18 & 17.2 & 0.68838 & 0.00042 \\
\hline P52rLx41 (s5) & 1 & 1,000 & 0.011 & 0.18 & 17.2 & 0.65991 & 0.00044 \\
\hline P52rLx41 (s5) & 1 & 500 & 0.011 & 0.18 & 17.2 & 0.67496 & 0.00045 \\
\hline P52rLx41 (s5) & 0.5 & 10,000 & 0.02 & 0.27 & 17.2 & 0.70739 & 0.00042 \\
\hline P52rLx41 (s5) & 0.5 & 10,000 & 0.011 & 0.18 & 17.2 & 0.45866 & 0.00028 \\
\hline P52\{rs\}L241 (s4) & 1 & 10,000 & 0.02 & 0.27 & 17.2 & 0.76445 & 0.00045 \\
\hline P52\{rs\}L241 (s4) & 1 & 1,000 & 0.02 & 0.27 & 17.2 & 0.80884 & 0.00046 \\
\hline P52\{rs\}L241 (s4) & 1 & 500 & 0.02 & 0.27 & 17.2 & 0.81939 & 0.00054 \\
\hline P52\{rs\}L241 (s4) & 1 & 100 & 0.02 & 0.27 & 17.2 & 0.85285 & 0.00048 \\
\hline P52\{rs\}L241 (s4) & 1 & 50 & 0.02 & 0.27 & 17.2 & 0.86603 & 0.00052 \\
\hline P52\{rs\}L241 (s4) & 1 & 10,000 & 0.011 & 0.18 & 17.2 & 0.47657 & 0.00031 \\
\hline P52\{rs\}L241 (s4) & 1 & 1,000 & 0.011 & 0.18 & 17.2 & 0.51490 & 0.00036 \\
\hline P52\{rs\}L241 (s4) & 1 & 100 & 0.011 & 0.18 & 17.2 & 0.55981 & 0.00033 \\
\hline P52\{rs\}L241 (s4) & 0.5 & 10,000 & 0.02 & 0.27 & 17.2 & 0.49239 & 0.00033 \\
\hline P52\{rs\}L241 (s4) & 0.5 & 10,000 & 0.011 & 0.18 & 17.2 & 0.27778 & 0.00018 \\
\hline
\end{tabular}

Table 8-8 (CRWMS M\&O 2001c, Table 6-3) lists the criticality evaluations for those accumulation cases in relatively large spherically shaped lithophysae only. The characteristic length is the diameter of the lithophysae. The Monte Carlo simulation determines the probability of having sufficient fractures intersecting the lithophysae to allow for sufficient dilution for accumulation. 
Table 8-7. Critical Volume for Accumulation in Fractures and Lithophysae as Equivalent Fractures

\begin{tabular}{|l|c|c|c|c|c|c|c|}
\hline $\begin{array}{c}\text { PHREEQC } \\
\text { Case Name }\end{array}$ & Saturation & $\begin{array}{c}\text { Inf. Rate } \\
\text { (I/year) }\end{array}$ & $\begin{array}{c}\text { Fracture } \\
\text { Porosity }\end{array}$ & $\begin{array}{c}\text { Lithophysae } \\
\text { Porosity }\end{array}$ & $\begin{array}{c}\text { Matrix } \\
\text { Porosity }\end{array}$ & $\mathbf{k}_{\text {eff }}$ & $\boldsymbol{\sigma}$ \\
\hline P52rLx41 (s5) & 1 & 10,000 & 0.027 & 0.27 & 17.2 & 0.99199 & 0.00065 \\
\hline $\begin{array}{l}\text { P52rLx41 (s5) } \\
\text { 10 Cells }\end{array}$ & 1 & 10,000 & 0.027 & 0.27 & 17.2 & 0.99152 & 0.00068 \\
\hline $\begin{array}{l}\text { P52rLx41 (s5) } \\
8 \text { Cells }\end{array}$ & 1 & 10,000 & 0.027 & 0.27 & 17.2 & 0.98346 & 0.00073 \\
\hline
\end{tabular}

Table 8-8. $\mathrm{k}_{\text {eff }}$ Values for Accumulation in Relatively Large Spherical Lithophysae

\begin{tabular}{|c|c|c|c|c|c|}
\hline $\begin{array}{c}\text { PHREEQC } \\
\text { Case Name }\end{array}$ & $\begin{array}{c}\text { Lithophysae } \\
\text { Diameter } \\
(\mathbf{m})\end{array}$ & $\begin{array}{c}\text { Percentage of } \\
\text { Lithophysae } \\
\text { Filled }\end{array}$ & $\begin{array}{c}\text { Number of } \\
\text { Fractures per } \\
\text { Lithophysae }\end{array}$ & $\mathbf{k}_{\text {eff }}$ & $\boldsymbol{\sigma}$ \\
\hline P52rLx41 (s5) & 1 & 0.9 & 12 & 0.79982 & 0.00095 \\
\hline P52rLx41 (s5) & 1 & 1.6 & 24 & 0.86895 & 0.00093 \\
\hline P52rLx41 (s5) & 1 & 2.3 & 36 & 0.92033 & 0.00097 \\
\hline P52rLx41 (s5) & 1 & 3.4 & 48 & 0.97190 & 0.99247 \\
\hline P52rLx41 (s5) & 1 & 3.9 & 61 & 0.99247 & 0.00100 \\
\hline P52rLx41 (s5) & 1 & 4.2 & 73 & 1.00017 & 0.00096 \\
\hline P52rLx41 (s5) & 1 & 6.0 & 85 & 1.04497 & 0.00078 \\
\hline P52rLx41 (s5) & 0.5 & 3.2 & 6 & 0.70437 & 0.00085 \\
\hline P52rLx41 (s5) & 0.5 & 6.8 & 12 & 0.82653 & 0.00095 \\
\hline P52rLx41 (s5) & 0.5 & 9.9 & 18 & 0.87627 & 0.00092 \\
\hline P52rLx41 (s5) & 0.5 & 12.7 & 24 & 0.90026 & 0.0094 \\
\hline P52rLx41 (s5) & 0.5 & 15.3 & 30 & 0.91476 & 0.00101 \\
\hline P52rLx41 (s5) & 0.5 & 18.5 & 36 & 0.95740 & 0.00092 \\
\hline P52rLx41 (s5) & 0.5 & 23.2 & 42 & 1.00053 & 0.00098 \\
\hline P52rLx41 (s5) & 0.25 & 13.2 & 3 & 0.67319 & 0.00085 \\
\hline P52rLx41 (s5) & 0.25 & 25.8 & 6 & 0.76953 & 0.00089 \\
\hline P52rLx41 (s5) & 0.25 & 39.5 & 9 & 0.76953 & 0.00089 \\
\hline P52rLx41 (s5) & 0.25 & 54.8 & 12 & 0.85241 & 0.00085 \\
\hline P52rLx41 (s5) & 0.25 & 67.2 & 15 & 0.89602 & 0.00095 \\
\hline P52rLx41 (s5) & 0.25 & 78.9 & 18 & 0.90774 & 0.00102 \\
\hline
\end{tabular}




\subsection{Probability of External Criticality}

Three systems are evaluated in the criticality calculation CRWMS M\&O 2001c. The first is a film accumulation system in a zone with fractures only, which resulted in no criticalities. This is mainly due to under-moderation as there is not enough void space to be filled with water to reach sufficient moderation levels to achieve criticality. The second is a film accumulation system in a lithophysal zone with fractures and lithophysae treated as equivalent fractures. This system with high enough fracture intensity and lithophysae porosity can be critical. In order to determine the critical volume for this case, the number of layers represented in the criticality evaluations is reduced until a change of the system reactivity is noticed. The remaining volume constitutes the minimum critical mass volume. The third system represents layer accumulation in relatively large spherical lithophysae. This case results in some criticalities under similar conditions that apply to the equivalent fracture representation. Section 8.4.1 lists the conditions for external criticality and their probabilities. Section 8.4.2 presents the probability of criticality for the film accumulation case. The probability of the critical cases in the layer accumulation in single relatively large spherical lithophysae representation is discussed in Section 8.4.3.

\subsubsection{External Criticality Conditions}

The overall probability of external criticality is determined as the product of the probabilities described in the following subsections.

The probability of criticality for film accumulation critical case in the lithophysal layer where lithophysae are treated as wide fractures depends on the following parameters.

\subsubsection{Zone in the Repository}

The only zone in the repository in which there is potential of external criticality is in the lithophysal zone (TSW35), which constitutes $80.4 \%$ of the repository (CRWMS M\&O 2001c, Section 5.3.1).

\subsubsection{Porosity}

Tuff porosity of 0.172 has a complimentary probability of 0.05 since the $95^{\text {th }}$ percentile of the tuff porosity is assumed (DTN: MO9708RIB00040.000).

Lithophysae porosity of 0.27 has a complimentary probability of 0.01 as interpolated from spreadsheet "lithophysae.xls" in Attachment I of CRWMS M\&O 2001c. The fracture porosity is closely related to the fracture intensity whose probability is described below.

\subsubsection{Climate}

As explained in Assumption 3.3.3, modern climate is assumed with a probability of 1 . 


\subsubsection{Seepage}

Modern climate has the highest probability of seepage rate between 1 and 20 liters per year of 0.221 as given in Table 5-21 of CRWMS M\&O (2001b).

\subsubsection{Flow into the Waste Package}

The maximum fraction of packages seeped on is 0.0694 as given in Table 5-23 of CRWMS M\&O (2001b).

\subsubsection{Probability of First Waste Package Breach}

The upper bound estimate of the fraction of waste packages failed (cracked) versus time to first failure in Figure 3.4-19 of CRWMS M\&O (2000b) shows that the first failure occurs at 10,500 years with a probability of 0.0005 .

\subsubsection{Fractures and Equivalent Fractures Dilution and Saturation}

The focused infiltration rate for the cases that have criticality potential is 10,000 liters/year at a saturation of $100 \%$. The effluent flux from the waste package is 1.5 liters per year. This results in a dilution factor of 6,667. Using Equation 8-1 as taken from Attachment VII of CRWMS M\&O (2001b), the probability of having such a high dilution factor for modern climate is $4.11 \times 10^{-12}$.

$$
\text { Probability }=0.2122 * \exp (-0.0037 * \text { dilution factor })
$$

\subsubsection{Fracture Intensity}

The accumulation of fissile material depends primarily on the fracture porosity, which is a combination of the fracture aperture and fracture intensity in units of $\mathrm{m}^{2} / \mathrm{m}^{3}$. Taking into account the three-dimensional nature of fractures, a conservative approximation to the number of fractures (nfracs) needed to achieve the accumulation necessary for a critical configuration is given by Equation 8-2 (CRWMS M\&O 2001e, Section 5.3.8). The division by three is very conservative since most fractures tend to be in the vertical direction. Since nfracs is used as an integer in the Monte Carlo code, as an additional conservatism, it is rounded down to an integer value.

$$
\text { nfracs }=\text { Fracture Intensity }\left(\mathrm{m}^{2} / \mathrm{m}^{3}\right) * \text { characteristic length }(\mathrm{m}) / 3
$$

The probability of nfracs sufficient for accumulation of a critical fissile mass is determined through a Monte Carlo simulation (CRWMS M\&O 2001c). Figure 8-3 (CRWMS M\&O 2001c, Figure 6-1) shows the results of the probability of a number of fractures intersecting the three characteristic lengths $0.9240,1.0$, and $0.5 \mathrm{~m}$, respectively, representative of the three critical cases. Probabilities below $10^{-9}$ cannot be determined by the Monte Carlo simulation (CRWMS M\&O 2001c). 


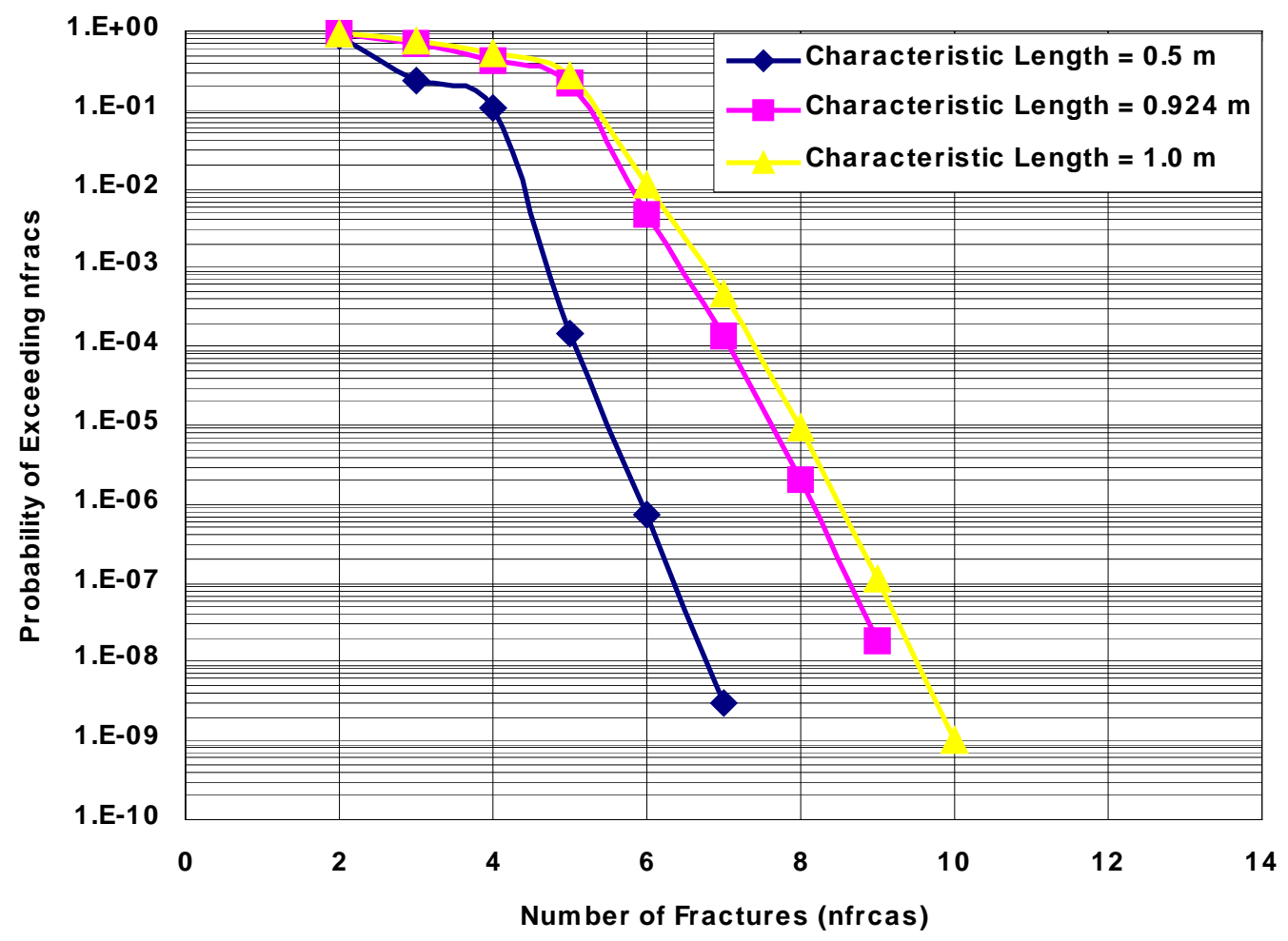

Figure 8-3. Probability of a Number of Fractures Intersecting a Characteristic Length 


\subsubsection{Probability of Film Accumulation}

One critical configuration is identified in the lithophysae equivalent fracture system. The characteristics and probabilities of this critical system are given in Table 8-9 (CRWMS M\&O 2001c, Table 6-4). The overall probability of criticality per plutonium-bearing waste package for this case is $1.67 \times 10^{-24}$. The total number of plutonium-bearing waste packages in the repository is approximately 700 (Shaw 2001, Table 2.3). The probability of criticality in the repository for this representation is $1.17 \times 10^{-21}$, which is the product of the probability of criticality per waste package $\left(1.67 \times 10^{-24}\right)$ and the total number of plutonium-bearing waste packages in the repository (700).

Table 8-9. Probability Summary of Critical Configuration for Equivalent Fracture System

\begin{tabular}{|l|l|l|}
\hline \multicolumn{1}{|c|}{ Parameter } & \multicolumn{1}{c|}{ Value } & \multicolumn{1}{c|}{ Probability } \\
\hline PHREEQC run & P52Lx41 (s5) & N/A \\
\hline k-effective +2 & 0.99288 & 1 \\
\hline Zone in the repository & $\mathrm{TSW} 35$ & 0.804 \\
\hline Number of cells in critical volume & 10 & $\mathrm{~N} / \mathrm{A}$ \\
\hline Critical volume & $0.413 \mathrm{~m}^{3}$ & $\mathrm{~N} / \mathrm{A}$ \\
\hline Characteristic length (diameter of sphere of equivalent volume) & $0.9240 \mathrm{~m}$ & $\mathrm{~N} / \mathrm{A}$ \\
\hline Lithophysae porosity & 0.27 & 0.01 \\
\hline Infiltration rate & 10,000 liters $/ \mathrm{year}$ & $4.1 \times 10^{-12}$ \\
\hline Fracture intensity & $25 \mathrm{~m}^{2} / \mathrm{m}^{3}$ (nfracs $\left.=7\right)$ & $1.32 \times 10^{-4}$ \\
\hline Climate & Modern & 1 \\
\hline Probability of a seepage rate & $1-20$ (liter $/ \mathrm{year})$ & 0.221 \\
\hline Fraction of packages seeped on & 0.0694 & 0.0694 \\
\hline Time to first waste package failure & 10,500 years & 0.0005 \\
\hline Saturation & 1 & 1 \\
\hline Tuff porosity & 0.172 & 0.05 \\
\hline Fracture Porosity & 0.027 & 1 \\
\hline Probability of criticality per plutonium-bearing waste package & $\mathrm{N} / \mathrm{A}$ & $1.67 \times 10^{-24}$ \\
\hline Total number of plutonium-bearing waste packages & $700^{\mathrm{a}}$ & $\mathrm{N} / \mathrm{A}$ \\
\hline Probability of external criticality in the repository & $\mathrm{N} / \mathrm{A}$ & $1.17 \times 10^{-21}$ \\
\hline
\end{tabular}

NOTE: ${ }^{a}$ The approximately 700 plutonium bearing waste packages is based on a $24.6 \mathrm{~kg}$ Pu loading per canister. The number of canisters required given in Table $2-11$ reflects a $27 \mathrm{~kg}$ Pu loading per canister as used in the source term calculations. This results in a more conservative probability estimate.

\subsubsection{Layer Accumulation Probability}

In the spherical representation of the relatively large lithophysae, criticality is contingent on having at least 61 or 42 fractures intersecting a 1 or 0.5 meter diameter lithophysae, respectively. The characteristics and probabilities of these critical systems are given in Tables 8-10 and 8-11 (CRWMS M\&O 2001c, Tables 6-5 and 6-6) for the 1- and 0.5-meter diameter lithophysae, respectively. The probability of criticality per plutonium-bearing waste package for the 1-meter diameter lithophysae is $6.17 \times 10^{-15}$. The probability of criticality per plutonium-bearing waste package for the 0.5 -meter diameter lithophysae is also $6.17 \times 10^{-15}$. The probabilities for the two systems are not really identical. This is just due to the conservative estimate for the probability of the minimum number of fractures intersecting a lithophysae $\left(10^{-9}\right)$. Extrapolating the probability estimates in Figure 8-3 clearly shows that the probability of having 20 fractures intersect a characteristic length of 1 meters or 14 fractures intersect a characteristic length of 0.5 meters are 
orders of magnitude less than $10^{-9}$. The probability of criticality in the repository for this representation is $4.32 \times 10^{-12}$.

Table 8-10. Summary of Critical Configuration for Spherical Representation of 1 meter Diameter Lithophysae

\begin{tabular}{|l|l|l|}
\hline \multicolumn{1}{|c|}{ Parameter } & \multicolumn{1}{c|}{ Value } & Probability \\
\hline PHREEQC run & P52rLx41 (s5) & N/A \\
\hline k-effective + 2 & 0.99447 & 1 \\
\hline Characteristic length (diameter lithophysae) & $1.0 \mathrm{~m}$ & $\mathrm{~N} / \mathrm{A}$ \\
\hline Climate & Modern & 1 \\
\hline Probability of desired seepage rate & $1-20$ liter/year & 0.221 \\
\hline Zone in the repository & $\mathrm{TSW} 35$ & 0.804 \\
\hline Fraction of packages seeped on & 0.0694 & 0.0694 \\
\hline Time to first waste package failure & 10,500 years & 0.0005 \\
\hline Minimum number of fractures intersecting a lithophysae & 61 (nfracs $=20)$ & $<1 \times 10^{-9}$ \\
\hline Probability of criticality per plutonium-bearing waste package & $\mathrm{N} / \mathrm{A}$ & $6.17 \times 10^{-15}$ \\
\hline Total number of plutonium-bearing waste packages & 700 & $\mathrm{~N} / \mathrm{A}$ \\
\hline Probability of external criticality in the repository & $\mathrm{N} / \mathrm{A}$ & $4.32 \times 10^{-12}$ \\
\hline
\end{tabular}

Table 8-11. Summary of Critical Configuration for Spherical Representation of 0.5 meter Diameter Lithophysae

\begin{tabular}{|l|l|l|}
\hline \multicolumn{1}{|c|}{ Parameter } & \multicolumn{1}{c|}{ Value } & Probability \\
\hline PHREEQC run & P52rLx41 (s5) & N/A \\
\hline k-effective +2 & 0.99447 & 1 \\
\hline Characteristic length (diameter lithophysae) & $0.5 \mathrm{~m}$ & $\mathrm{~N} / \mathrm{A}$ \\
\hline Climate & Modern & 1 \\
\hline Probability of desired seepage rate & $1-20$ liter/year & 0.221 \\
\hline Zone in the repository & $\mathrm{TSW} 35$ & 0.804 \\
\hline Fraction of packages seeped on & 0.0741 & 0.0694 \\
\hline Time to first waste package failure & 10,500 years & 0.0005 \\
\hline Minimum number of fractures intersecting a lithophysae & 61 (nfracs $=20)$ & $<1 \times 10^{-9}$ \\
\hline Probability of criticality per plutonium-bearing waste package & $\mathrm{N} / \mathrm{A}$ & $6.17 \times 10^{-15}$ \\
\hline Total number of plutonium-bearing waste packages & 700 & $\mathrm{~N} / \mathrm{A}$ \\
\hline Probability of external criticality in the repository $\left(\mathrm{y}^{-1}\right)$ & $\mathrm{N} / \mathrm{A}$ & $4.32 \times 10^{-12}$ \\
\hline
\end{tabular}




\section{FINDINGS AND CONCLUSIONS}

This document may be affected by technical product input information that requires confirmation. Any changes to the document or its conclusions that may occur as a result of completing the confirmation activities will be reflected in subsequent revisions. The status of the technical product input information quality may be confirmed by review of the Document Input Reference System (DIRS) database.

The following are the principal findings from this study:

\section{- Waste Package Degradation}

- Gadolinium loss from the WP observed in the current study is consistently lower than observed in the previous study (CRWMS M\&O 1999a). Thus, there are no viable internal criticality scenarios resulting from degradation of the Pu-ceramic waste form.

- Significant losses of fissile Pu (material with highest criticality potential) from the waste package occurred only for degradation cases where environmental conditions were specifically designed to maximize the mobility of the $\mathrm{Pu}$, i.e., initially high $\mathrm{pH}$, low steel degradation rate, and high ceramic and glass degradation rates. The maximum release of $\mathrm{Pu}$ from the WP under nominal conditions was $<15 \mathrm{~kg}$, which is approximately $55 \%$ of the initial loading of one canister.

\section{- External Far-Field Accumulation of Fissile Material}

- Fissile material can accumulate as a thin film on the walls of fractures and lithophysae given the appropriate dilution conditions.

- Fissile material can also accumulate as a layer at the bottom of relatively large lithophysae given the appropriate number of fractures intersecting a single lithophysae.

- Lithophysae vary in size and volume fraction in their rock layers up to maximums of approximately 1 meter in diameter and $27 \%$ volume fractions.

- The accumulation density of fissile material is inversely proportional to the dilution factor.

- Minor variations in the dissolved mineral content of the resident water (J-13 or pore water specifications) had only a minor effect on the accumulation levels.

- Significant accumulations of $\mathrm{Pu}$ in the rock fractures and lithophysae required a minimum of two Pu-ceramic canisters per WP.

- Increasing the infiltration rate increases the accumulation radius and decreases the accumulation depth. 
- Increasing effluent flux or system porosity increases the accumulation radius and maintains the accumulation depth.

- Increasing the fracture intensity, aperture size, or saturation level decreases the accumulation radius and maintains the accumulation depth.

\section{- Probability of External Criticality}

- External criticality in non-lithophysal zones is not possible even when using all the upper bounds of the distributions applicable to such a zone. This result is mainly due to insufficient moderation.

- The potential for criticality in the lithophysal zone is conditioned by the occurrence of many unlikely scenarios whose maximum combined probability of $4.32 \times 10^{-12}$ per year is well below the criticality screening threshold of $1.0 \times 10^{-8}$ per year (YMP 2000, Section 3.2.2)

An extremely conservative approach was employed in estimating the overall probability of criticality. Many parameters are optimized to result in the highest possible probability of criticality without taking probability credit for them. In the degradation analysis (CRWMS M\&O 2001a), the source term was optimized by varying the degradation rate of the three main components of a plutonium-bearing waste package, i.e., SS, HLW glass, and ceramic. The source term was optimized such that its chemistry is favorable for high solubility of fissile material while maintaining favorable chemistry for accumulation in the external environment with reasonable dilution. Probability credit for the conservative degradation rates is not taken and neither was any credit taken for source term optimization.

It is important to understand that the estimation of the probability of criticality external to waste packages bearing plutonium disposition ceramic waste form is highly dependent on the theory behind accumulation mechanisms. The probability presented in this report is linked to the neutralization accumulation mechanism in an assumed geometry. Currently, this is the mechanism that is believed to result in the highest accumulations of fissile materials. The assumed geometry is needed because of the limitations of PHREEQC, which is the only tool available for such purposes. Even though the extreme conservatism presented in this report is defendable and reliable, it is not comprehensive of all accumulation mechanisms. 


\section{REFERENCES}

\subsection{DOCUMENTS CITED}

Baxter, R. G. 1988. Defense Waste Processing Facility Waste form and Canister Description. DP1606, Rev. 2. Aiken, South Carolina: Savannah River Plant. TIC: 8704.

Briesmeister, J.F., ed. 1997. MCNP-A General Monte Carlo N-Particle Transport Code. LA12625-M, Version 4B. Los Alamos, New Mexico: Los Alamos National Laboratory. ACC: MOL.19980624.0328.

CRWMS M\&O 1998a. EQ6 Calculations for Chemical Degradation of Pu-Ceramic Waste Packages. BBA000000-01717-0210-00018 REV 00. Las Vegas, Nevada: CRWMS M\&O. ACC: MOL.19980918.0004.

CRWMS M\&O 1998b. Software Qualification Report for MCNP Version 4B2, A General Monte Carlo N-Particle Transport Code. CSCI: 30033 V4B2LV. DI: 30033-2003, Rev. 01. Las Vegas, Nevada: CRWMS M\&O. ACC: MOL.19980622.0637.

CRWMS M\&O 1998c. Software Qualification Report (SQR) Addendum to Existing LLNL Document UCRL-MA-110662 PT IV: Implementation of a Solid-Centered Flow-Through Mode for EQ6 Version 7.2B. CSCI: UCRL-MA-110662 V 7.2b. SCR: LSCR198. Las Vegas, Nevada: CRWMS M\&O. ACC: MOL.19990920.0169.

CRWMS M\&O 1998d. EQ6 Calculations for Chemical Degradation of Fast Flux Test Facility (FFTF) Waste Packages. BBA000000-01717-0210-00028 REV 00. Las Vegas, Nevada: CRWMS M\&O. ACC: MOL.19981229.0081.

CRWMS M\&O 1998e. Software Code: MCNP. 4B2LV. HP. 30033 V4B2LV.

CRWMS M\&O 1999a. EQ6 Calculation for Chemical Degradation of Pu-Ceramic Waste Packages: Effects of Updated Materials Composition and Rates. CAL-EDC-MD-000003 REV 00. Las Vegas, Nevada: CRWMS M\&O. ACC: MOL.19990928.0235.

CRWMS M\&O 1999b. Software Validation Test Report (VTR) for PHREEQC Version 2.0 (beta). SDN: 10068-VTR-2.0-00. Las Vegas, Nevada: CRWMS M\&O. ACC: MOL.20000113.0408.

CRWMS M\&O 1999c. Software Code: PHREEQC. V2.0. PC. 10068-2.0-00.

CRWMS M\&O 1999d. Software User's Manual (UM) for PHREEQC Version 2.0 (beta). SDN: 10068-UM-2.0-00. Las Vegas, Nevada: CRWMS M\&O. ACC: MOL.20000114.0118.

CRWMS M\&O 1999e. Software Code: EQ6, Version 7.2bLV. V7.2bLV. 10075-7.2bLV-00.

CRWMS M\&O 2000a. Technical Work Plan for: Plutonium Disposition Work Packages. TWPMGR-MD-000011 REV 00. Las Vegas, Nevada: CRWMS M\&O. ACC: MOL.20001106.0243. 
CRWMS M\&O 2000b. Total System Performance Assessment for the Site Recommendation. TDRWIS-PA-000001 REV 00 ICN 01. Las Vegas, Nevada: CRWMS M\&O. ACC: MOL.20001220.0045.

CRWMS M\&O 2000c. Abstraction of Drift Seepage. ANL-NBS-MD-000005 REV 00. Las Vegas, Nevada: CRWMS M\&O. ACC: MOL.20000322.0671.

CRWMS M\&O 2000d. Not used.

CRWMS M\&O 2000e. Validation Test Report for EQ6 V7.2bLV. SDN: 10075-VTR-7.2bLV-00. Las Vegas, Nevada: CRWMS M\&O. ACC: MOL.20000124.0135.

CRWMS M\&O 2000f. Probability of External Criticality of Plutonium Disposition Waste Forms. CAL-EBS-NU-000011 REV 00. Las Vegas, Nevada: CRWMS M\&O. ACC: MOL.20000920.0164.

CRWMS M\&O 2000g. Not Used.

CRWMS M\&O 2000h. Design Analysis for the Defense High-Level Waste Disposal Container. ANL-DDC-ME-000001 REV 00. Las Vegas, Nevada: CRWMS M\&O. ACC: MOL.20000627.0254.

CRWMS M\&O 2000i. Not used.

CRWMS M\&O 2000j. In-Drift Accumulation of Fissile Material from Waste Packages Containing Plutonium Disposition Waste Forms. CAL-EDC-GS-000001 REV 00. Las Vegas, Nevada: CRWMS M\&O. ACC: MOL.20001016.0008.

CRWMS M\&O 2000k. Waste Package Related Impacts of Plutonium Disposition Waste Forms in a Geologic Repository. TDR-EBS-MD-000003 REV 01 ICN 01. Las Vegas, Nevada: CRWMS M\&O. ACC: MOL.20000510.0163.

CRWMS M\&O 20001. Analysis of Geochemical Data for the Unsaturated Zone. ANL-NBS-HS000017 REV 00. Las Vegas, Nevada: CRWMS M\&O. ACC: MOL.20000725.0453.

CRWMS M\&O 2001a. EQ6 Calculation for Chemical Degradation of Pu-Ceramic Waste Packages: Effects of Updated Waste Package Design and Rates. Input Transmittal 00434.T. Las Vegas, Nevada: CRWMS M\&O. ACC: MOL.20010302.0005.

CRWMS M\&O 2001b. External Accumulation of Fissile Material from Waste Packages Containing Plutonium Ceramics: Updated Model. Input Transmittal 00433.T. Las Vegas, Nevada: CRWMS M\&O. ACC: MOL.20010302.0006. 
CRWMS M\&O 2001c. External Criticality Evaluation of the Plutonium Disposition Ceramic Waste Form. Input Transmittal 00437.T. Las Vegas, Nevada: CRWMS M\&O. ACC: MOL.20010308.0198.

CRWMS M\&O 2001d. Description of Fracture Systems for External Criticality Reports. Input Transmittal 00435.T. Las Vegas, Nevada: CRWMS M\&O. ACC: MOL.20010302.0004.

CRWMS M\&O 2001e. Defense High Level Waste Glass Degradation. ANL-EBS-MD-000016 REV 00 ICN 1. Las Vegas, Nevada: CRWMS M\&O. ACC: MOL.20010130.0004.

Daveler, S.A. and Wolery, T.J. 1992. EQPT, A Data File Preprocessor for the EQ3/6 Software Package. User's Guide, and Related Documentation (Version 7.0). UCRL-MA-110662 PT II. Livermore, California: Lawrence Livermore National Laboratory. TIC: 205240.

DOE (U.S. Department of Energy) 1996. Waste Acceptance Product Specifications for Vitrified High-Level Waste Forms. DOE/EM-WAPS, Rev. 02. Washington, D.C.: U.S. Department of Energy. TIC: 234751.

DOE (U.S. Department of Energy) 2000. Quality Assurance Requirements and Description. DOE/RW-0333P, Rev. 10. Washington, D.C.: U.S. Department of Energy, Office of Civilian Radioactive Waste Management. ACC: MOL.20000427.0422.

Domenico, P.A. and Schwartz, F.W. 1990. Physical and Chemical Hydrogeology. New York, New York: John Wiley \& Sons. TIC: 234782.

Harrar, J.E.; Carley, J.F.; Isherwood, W.F.; and Raber, E. 1990. Report of the Committee to Review the Use of J-13 Well Water in Nevada Nuclear Waste Storage Investigations. UCID-21867. Livermore, California: Lawrence Livermore National Laboratory. ACC: NNA.19910131.0274.

Latimer, W.M. 1952. The Oxidation States of the Elements and Their Potentials in Aqueous Solutions. 2nd Edition. Pages 8, 9, 30, 215, 270-274. New York, New York: Prentice-Hall. TIC: 238748.

Lipman, P.W.; Christiansen, R.L.; and O'Connor, J.T. 1966. A Compositionally Zoned Ash-Flow Sheet in Southern Nevada. Professional Paper 524-F. Washington, D.C.: U.S. Geological Survey. TIC: 219972.

LLNL (Lawrence Livermore National Laboratory) 1998. Plutonium Immobilization Project Data for Yucca Mountain Total Systems Performance Assessment, Rev. 1. PIP 98-012. Livermore, California: Lawrence Livermore National Laboratory. ACC: MOL.19980818.0349.

LLNL (Lawrence Livermore National Laboratory) 1999. Software Code: EQ3/6 . V7.2b. PC. LLNL: UCRL-MA-110662. 
Marshall, B.D.; Neymark, L.A.; Paces, J.B.; Peterman, Z.E.; and Whelan, J.F. 2000. "Seepage Flux Conceptualized from Secondary Calcite in Lithophysal Cavities in the Topopah Spring Tuff, Yucca Mountain, Nevada." SME Annual Meeting, February 28-March 1, 2000, Salt Lake City, Utah. Preprint 00-12. [Littleton, Colorado]: Society for Mining, Metallurgy, and Exploration. TIC: 248608.

Paces, J.B.; Neymark, L.A.; Marshall, B.D.; Whelan, J.F.; and Peterman, Z.E. 1996. Letter Report: Ages and Origins of Subsurface Secondary Minerals in the Exploratory Studies Facility (ESF). Milestone 3GQH450M, Results of Sampling and Age Determination. Las Vegas, Nevada: U.S. Geological Survey. ACC: MOL.19970324.0052.

Philip, J.R.; Knight, J.H.; and Waechter, R.T. 1989. "Unsaturated Seepage and Subterranean Holes: Conspectus, and Exclusion Problem for Circular Cylindrical Cavities." Water Resources Research, 25, (1), 16-28. Washington, D.C.: American Geophysical Union. TIC: 239117.

Shaw, H., ed. 1999. Plutonium Immobilization Project Input for Yucca Mountain Total Systems Performance Assessment. PIP-99-107. Livermore, California: Lawrence Livermore National Laboratory. TIC: 245437.

Shaw, H.F.; Ebbinghaus, B.B.; Bourcier, W.L.; and Gray, L. 2001. Plutonium Immobilization Project Input for Yucca Mountain Total Systems Performance Assessment. PIP-01-004, Rev. 4.0. Livermore, California: Lawrence Livermore National Laboratory. TIC: 249220.

Weast, R.C., ed. 1977. CRC Handbook of Chemistry and Physics. 58th Edition. Cleveland, Ohio: CRC Press. TIC: 242376.

Yang, I.C.; Rattray, G.W.; and Yu, P. 1996. Interpretation of Chemical and Isotopic Data from Boreholes in the Unsaturated Zone at Yucca Mountain, Nevada. Water-Resources Investigations Report 96-4058. Denver, Colorado: U.S. Geological Survey. ACC: MOL.19980528.0216.

YMP (Yucca Mountain Site Characterization Project) 2000. Disposal Criticality Analysis Methodology Topical Report. YMP/TR-004Q, Rev. 01. Las Vegas, Nevada: Yucca Mountain Site Characterization Office. ACC: MOL.20001214.0001.

\subsection{CODES, STANDARDS, REGULATIONS, AND PROCEDURES}

65 FR 1608. Record of Decision for the Surplus Plutonium Disposition Final Environment Impact Statement. TIC: 248241.

AP-2.14Q, Rev. 1, BSCN 1. Review of Technical Products and Data. Washington, D.C.: U.S. Department of Energy, Office of Civilian Radioactive Waste Management. ACC: MOL.20010212.0001.

AP-2.21Q, Rev. 1, BSCN 1. Quality Determinations and Planning for Scientific, Engineering, and Regulatory Compliance Activities. Washington, D.C.: U.S. Department of Energy, Office of Civilian Radioactive Waste Management. ACC: MOL.20010212.0018. 
AP-3.11Q, Rev. 1, ICN 3 BSCN 1. Technical Reports. Washington, D.C.: U.S. Department of Energy, Office of Civilian Radioactive Waste Management. ACC: MOL.20001212.0019.

AP-3.12Q, Rev. 0, ICN 3, BSCN 1. Calculations. Washington, D.C.: U.S. Department of Energy, Office of Civilian Radioactive Waste Management. ACC: MOL.20010212.0020.

AP-3.14Q, Rev. 0, ICN 2, BSCN 1. Transmittal of Input. Washington, D.C.: U.S. Department of Energy, Office of Civilian Radioactive Waste Management. ACC: MOL.20010212.0022.

AP-3.15Q, Rev. 2, BSCN 1. Managing Technical Product Inputs. Washington, D.C: U.S. Department of Energy, Office of Civilian Radioactive Waste Management. ACC: MOL.20010212.0023.

AP-SI.1Q, Rev. 2, ICN 4, ECN 1. Software Management. Washington, D.C.: U.S. Department of Energy, Office of Civilian Radioactive Waste Management. ACC: MOL.20001019.0023.

AP-SV.1Q, Rev. 0, ICN 2. Control of the Electronic Management of Data. Washington, D.C.: U.S. Department of Energy, Office of Civilian Radioactive Waste Management. ACC: MOL.20000831.0065.

\subsection{SOURCE DATA, LISTED BY DATA TRACKING NUMBER}

MO0006J13WTRCM.000. Recommended Mean Values of Major Constituents in J-13 Well Water. Submittal date: 06/07/2000.

MO9708RIB00040.000. RIB Item\#40/REV0: Hydrologic Characteristics: Hydrogeologic Unit Characteristics. Submittal date: 08/29/1997. Submit to RPC. URN-0534. 


\section{INTENTIONALLY LEFT BLANK}

